\title{
Geochemical, biological and clumped isotopologue evidence for substantial microbial methane production under carbon limitation in serpentinites of the Samail Ophiolite, Oman
}

\author{
Daniel B. Nothaft ${ }^{1}$, Alexis S. Templeton ${ }^{1}$, Jeemin H. Rhim ${ }^{2}$, David T. Wang ${ }^{2 *}$ \\ , Jabrane Labidi ${ }^{3}$, Hannah M. Miller ${ }^{1 \dagger}$, Eric S. Boyd ${ }^{4}$, Juerg M. Matter ${ }^{5}$, \\ Shuhei Ono ${ }^{2}$, Edward D. Young ${ }^{3}$, Sebastian H. Kopf ${ }^{1}$, Peter B. Kelemen ${ }^{6}$, \\ Mark E. Conrad ${ }^{7}$, The Oman Drilling Project Science Team

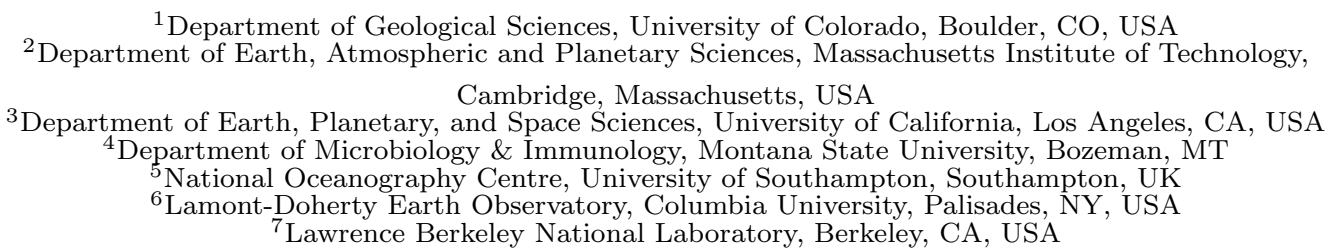

Key Points:

- 16S rRNA gene sequences affiliated with methanogens and $\mathrm{CH}_{4}$ clumped isotopologue compositions suggest substantial microbial $\mathrm{CH}_{4}$ production.

- A second $\mathrm{CH}_{4}$ source, release of $\mathrm{CH}_{4}$ from fluid inclusions, is indicated by ${ }^{13} \mathrm{C}$ enriched ethane and propane.

- Scarcity of $\mathrm{C}$ substrates $\left(\mathrm{CO}_{2}\right.$ and formate) may decrease the apparent $\mathrm{C}$ isotope effect of microbial methanogenesis.

\footnotetext{
*Current address: ExxonMobil Upstream Research Company, Spring, TX 77389, USA

${ }^{\dagger}$ Current address: Itasca Denver, Inc., 143 Union Blvd. Suite 525 Lakewood, CO 80228, USA
}

Corresponding author: Daniel B. Nothaft, daniel.nothaft@colorado.edu

Corresponding author: Alexis S. Templeton, alexis.templeton@colorado.edu 


\begin{abstract}
In hyperalkaline $(\mathrm{pH}>10)$ fluids that have participated in low-temperature $\left(<150{ }^{\circ} \mathrm{C}\right)$ serpentinization reactions, the dominant form of $\mathrm{C}$ is often methane $\left(\mathrm{CH}_{4}\right)$, but the origin of this $\mathrm{CH}_{4}$ is uncertain. To assess $\mathrm{CH}_{4}$ origin in serpentinite aquifers within the Samail Ophiolite, Oman, we determined fluid chemical compositions, analyzed taxonomic profiles of fluid-hosted microbial communities, and measured isotopic compositions of hydrocarbon gases. We found that $16 \mathrm{~S}$ rRNA gene sequences affiliated with methanogens were widespread in the aquifer. We measured clumped isotopologue $\left({ }^{13} \mathrm{CH}_{3} \mathrm{D}\right.$ and $\left.{ }^{12} \mathrm{CH}_{2} \mathrm{D}_{2}\right)$ relative abundances less than equilibrium, consistent with substantial microbial $\mathrm{CH}_{4}$ production. Further, we observed an inverse relationship between dissolved inorganic $\mathrm{C}$ concentrations and $\delta^{13} \mathrm{C}_{\mathrm{CH}_{4}}$ across fluids bearing microbiological evidence of methanogenic activity, suggesting that the apparent $\mathrm{C}$ isotope effect of microbial methanogenesis is modulated by $\mathrm{C}$ availability. An additional source of $\mathrm{CH}_{4}$ is evidenced by the presence of $\mathrm{CH}_{4}$ bearing fluid inclusions in the Samail Ophiolite and our measurement of high $\delta^{13} \mathrm{C}$ values of ethane and propane, which are similar to those reported in studies of $\mathrm{CH}_{4}$-rich inclusions in rocks from the oceanic lithosphere. In addition, we observed 16S rRNA gene sequences affiliated with aerobic methanotrophs and, in lower abundance, anaerobic methanotrophs, indicating that microbial consumption of $\mathrm{CH}_{4}$ in the ophiolite may further enrich $\mathrm{CH}_{4}$ in ${ }^{13} \mathrm{C}$. We conclude that substantial microbial $\mathrm{CH}_{4}$ is produced under varying degrees of $\mathrm{C}$ limitation and mixes with abiotic $\mathrm{CH}_{4}$ released from fluid inclusions. This study lends insight into the functioning of microbial ecosystems supported by water/rock reactions.
\end{abstract}

\title{
Plain Language Summary
}

Mantle rocks from beneath Earth's crust can be thrust to the surface, where they are exposed to rain and air containing carbon dioxide $\left(\mathrm{CO}_{2}\right)$. The groundwaters that become stored in these rocks often contain methane $\left(\mathrm{CH}_{4}\right.$, a major component of "natural gas"), which can be formed from carbon dioxide in the subsurface. To investigate these methane-forming processes, we sampled water, gas, and suspended particles from groundwaters using wells previously drilled into the rocks. The particles contained microbes with the genetic ability to produce methane. We also precisely measured the amounts of combinations of $\mathrm{C}$ and $\mathrm{H}$ atoms of different masses (isotopes) in the natural gas to determine how it was formed. The results of these measurements suggest that microbes could actively produce a considerable amount of the methane, which mixes with methane from another source that was formed by non-biological processes, possibly long ago under different conditions than today's. Rocks like those studied here are widespread in the Solar System, so our finding that microbes live and produce methane in these rocks could help guide the search for life beyond Earth.

\section{Introduction}

At temperatures and pressures near the Earth's surface $\left(<400{ }^{\circ} \mathrm{C},<100 \mathrm{MPa}\right)$, ultramafic rocks such as peridotite in contact with water are thermodynamically driven to hydrate and oxidize, forming variable amounts of serpentine, magnetite, brucite, hydrogen $\left(\mathrm{H}_{2}\right)$, and other phases (Evans, 1977; Frost, 1985; McCollom \& Bach, 2009; Klein \& Bach, 2009; Klein et al., 2009, 2019). This process, often called "serpentinization", can produce $\mathrm{H}_{2}$ at temperatures at least as low as $55^{\circ} \mathrm{C}$ (Miller, Mayhew, et al., 2017). The resultant $\mathrm{H}_{2}$ can be thermodynamically favored to reduce carbon dioxide $\left(\mathrm{CO}_{2}\right)$ to methane $\left(\mathrm{CH}_{4}\right)$ (Shock, 1992). The reduction of $\mathrm{CO}_{2}$ by $\mathrm{H}_{2}$ to form $\mathrm{CH}_{4}$ can be catalyzed on mineral surfaces as in the Sabatier reaction (Etiope \& Ionescu, 2015; Klein et al., 2019), or enzymatically through microbial methanogenesis (Whiticar, 1999).

In continental settings undergoing serpentinization, where fluid-rock reactions typically occur at low temperatures $\left(<150^{\circ} \mathrm{C}\right)$, there is disagreement regarding the ori- 
gin of $\mathrm{CH}_{4}$. Three key potential $\mathrm{CH}_{4}$ sources have been identified in these environments. One potential source is the abiotic reduction of $\mathrm{CO}_{2}$ to $\mathrm{CH}_{4}$ at warmer-than-present temperatures in fluid inclusions within crystals that can store $\mathrm{CH}_{4}$ and subsequently release it. Another potential source is the abiotic, mineral-catalyzed reduction of $\mathrm{CO}_{2}$ to $\mathrm{CH}_{4}$ at the low temperatures that prevail in the present-day weathering environment. A third potential source is microbial methanogenesis.

Storage of $\mathrm{CH}_{4}$ produced at temperatures of $270^{\circ} \mathrm{C}$ to $800^{\circ} \mathrm{C}$ in fluid inclusions in minerals such as olivine and the release of this $\mathrm{CH}_{4}$ through subsequent chemical/physical alteration are the dominant processes contributing to $\mathrm{CH}_{4}$ fluxes from sediment-poor seafloor hydrothermal vents (Kelley, 1996; Kelley \& Früh-Green, 1999; McDermott et al., 2015; D. T. Wang et al., 2018; Labidi et al., 2020). In continental, low-temperature serpentinizing settings, however, debate continues as to whether fluid inclusions can sustain observed $\mathrm{CH}_{4}$ fluxes (Etiope \& Whiticar, 2019; Grozeva et al., 2020).

Abiotic reduction of $\mathrm{CO}_{2}$ to $\mathrm{CH}_{4}$ can occur at temperatures at least as low as $20^{\circ} \mathrm{C}$ when catalyzed by the transition metal ruthenium (Ru) (Etiope \& Ionescu, 2015). Ru is present in considerable abundance in chromitite bodies in ultramafic rock accumulations (Etiope et al., 2018), but it has only been shown to catalyze $\mathrm{CO}_{2}$ hydrogenation under conditions where free gas phases exist (Etiope \& Ionescu, 2015). The prevalence of this process, particularly in aquifers whose fluid compositions appear to be dominantly influenced by aqueous reactions with harzburgite, is another matter of ongoing debate (Etiope, 2017; Miller, Matter, et al., 2017).

Low-temperature $\mathrm{CH}_{4}$ production can also be mediated by microbes called "methanogens". Microbial $\mathrm{CH}_{4}$ has traditionally been viewed as a minor/negligible source of $\mathrm{CH}_{4}$ in serpentinizing settings. This is due in large part to the relatively ${ }^{13} \mathrm{C}$-enriched composition of $\mathrm{CH}_{4}$ in serpentinizing settings $\left(\delta^{13} \mathrm{C}\right.$ commonly $-20 \%$ VPDB to $5 \%$ VPDB), which contrasts with the more ${ }^{13} \mathrm{C}$-depleted composition of $\mathrm{CH}_{4}$ in sedimentary settings dominated by microbial methanogenesis $\left(\delta^{13} \mathrm{C}\right.$ commonly $-90 \%$ VPDB to $-50 \%$ VPDB $)$ (Etiope, 2017; Milkov \& Etiope, 2018; Etiope \& Whiticar, 2019). However, cultures of methanogens can produce $\mathrm{CH}_{4}$ with minimal $\mathrm{C}$ isotope fractionation in $\mathrm{H}_{2}$-rich, $\mathrm{CO}_{2}$ poor fluids simulating serpentinizing systems (Miller et al., 2018). In these cultures, it has been inferred that the net $\mathrm{C}$ isotope effect of methanogenesis was attenuated due to microbial conversion of a large proportion of available $\mathrm{CO}_{2}$ to $\mathrm{CH}_{4}$ when $\mathrm{CO}_{2}$ was the limiting substrate. Such results illustrate that ${ }^{13} \mathrm{C}$-enriched $\mathrm{CH}_{4}$ in natural serpentinizing settings does not necessarily derive from non-microbial sources. Still, the quantity and isotopic composition of microbial $\mathrm{CH}_{4}$ in serpentinizing settings remains uncertain.

In this study, we assessed sources and sinks of $\mathrm{CH}_{4}$ in the Samail Ophiolite of Oman, a site of active, low-temperature serpentinization and carbonation. Fluids and particulates in groundwaters accessed via wells in the Samail Ophiolite have been sampled for biogeochemical studies annually from 2014 through 2018 from January to March. Microbiological and geochemical data from sampling campaigns in 2014 through 2017 and a limited number of $\mathrm{C}$ and $\mathrm{H}$ bulk stable isotope analyses of $\mathrm{CH}_{4}$ sampled in 2014 have been previously reported (Miller et al., 2016; Rempfert et al., 2017; Kraus et al., 2021; Fones et al., 2019, 2020) Here, we present new geochemical and 16S rRNA gene amplicon sequencing data from samples acquired in 2018 . We also present new bulk stable isotope data on $\mathrm{CH}_{4}$, ethane $\left(\mathrm{C}_{2} \mathrm{H}_{6}\right)$, and propane $\left(\mathrm{C}_{3} \mathrm{H}_{8}\right)$ from samples obtained from 2015 through 2018. Further, we report analyses of multiply-substituted "clumped" isotopologues of $\mathrm{CH}_{4},{ }^{13} \mathrm{CH}_{3} \mathrm{D}$ and ${ }^{12} \mathrm{CH}_{2} \mathrm{D}_{2}$, for the first time on samples from this ophiolite. Leveraging one of the largest longitudinal data sets on $\mathrm{CH}_{4}$ biogeochemistry in an ophiolite, we have identified robust trends across years and hydrogeologic settings. We observed a wide range of $\mathrm{C}$ isotopic compositions of $\mathrm{CH}_{4}$ and short-chain alkanes, intramolecular isotopologue disequilibrium in $\mathrm{CH}_{4}$, and widespread occurrence of gene sequences affiliated with methanogens, which collectively indicate that substantial quantities of microbial $\mathrm{CH}_{4}$ are produced and mix with abiotic $\mathrm{CH}_{4}$ released from fluid inclusions in the 
Samail Ophiolite. Our finding that microbial methanogenesis proceeds even in hyperalkaline fluids lends insight into the functioning of microbial ecosystems that leverage reactions between water and ultramafic rocks to power metabolic processes on Earth and perhaps on other rocky bodies of the Solar System (Ménez, 2020; Glein \& Zolotov, 2020).

\section{Geologic Setting}

The Samail Ophiolite (Figure 1) consists of pelagic sedimentary rocks $(<0.1 \mathrm{~km})$, volcanic rocks $(0.5 \mathrm{~km}$ to $2.0 \mathrm{~km})$, sheeted dikes ( $1 \mathrm{~km}$ to $1.5 \mathrm{~km})$, gabbro and igneous peridotite $(0.5 \mathrm{~km}$ to $6.5 \mathrm{~km})$, residual mantle peridotites, $(8 \mathrm{~km}$ to $12 \mathrm{~km})$, and a metamorphic sole of greenschist- to granulite-facies metamorphic rocks $(<0.5 \mathrm{~km})$ (Glennie et al., 1973; Coleman \& Hopson, 1981; Lippard et al., 1986; Nicolas, 1989; Nicolas et al., 2000). The ophiolite crust formed from 96.12 Ma to $95.50 \mathrm{Ma}$, and convergence began at about the same time (Rioux et al., 2016), or up to $10 \mathrm{Myr}$ earlier (Guilmette et al., 2018; Soret et al., 2020). Ophiolite emplacement continued until 78 Ma to $71 \mathrm{Ma}$ (Rabu et al., 1993). Part of the ophiolite was subaerially eroded in the Late Cretaceous, then became covered in parts by Maastrictian to Eocene limestones due to subsidence and transgression (Nolan et al., 1990; Skelton et al., 1990).

The mantle section of the ophiolite is mainly composed of highly depleted, residual mantle harzburgites, together with $5 \%$ to $15 \%$ dunite, which both contain a few percent chromian spinel (Godard et al., 2000; Hanghøj et al., 2010; Boudier \& Coleman, 1981; Collier, 2012). The extent of serpentinization is typically $30 \%$ to $60 \%$, reaching $100 \%$ in some cases (Dewandel et al., 2003; Boudier et al., 2009; Miller et al., 2016; P. Kelemen et al., 2020). Chromitites are most often found in association with dunites near the crust-mantle transition, possibly representing bases of cumulate piles, but are also found dispersed throughout the mantle section (Rollinson, 2005).

Geologic reservoirs of $\mathrm{C}$ underlying the ophiolite include Mid Permian to Late Cretaceous shallow marine carbonates, which host oil and gas fields in parts of northern Oman and the United Arab Emirates (Terken, 1999; Alsharhan, 1989; Etiope et al., 2015). Maastrictian to Eocene limestones that partially overly the ophiolite have been shown to transfer inorganic C to peridotites where they are in contact (de Obeso \& Kelemen, 2018). $\mathrm{C}$ is also stored within the ophiolite, primarily in the form of carbonate minerals (Neal \& Stanger, 1985; P. B. Kelemen \& Matter, 2008; P. B. Kelemen et al., 2011; Noël et al., 2018). Hydration and carbonation of $>20000 \mathrm{~km}^{3}$ of peridotite continue today in the Samail Ophiolite, largely at $<60^{\circ} \mathrm{C}$ (Neal \& Stanger, 1983, 1985; P. B. Kelemen \& Matter, 2008; P. B. Kelemen et al., 2011; Streit et al., 2012; A. N. Paukert et al., 2012; Chavagnac, Ceuleneer, et al., 2013; Chavagnac, Monnin, et al., 2013; Mervine et al., 2014; Falk et al., 2016; Miller et al., 2016; Paukert Vankeuren et al., 2019).

\section{Methods}

\subsection{Fluid sampling and field measurements}

Wells were drilled into the Samail Ophiolite by the Ministry of Regional Municipalities and Water Resources of the Sultanate of Oman prior to 2006 ("WAB" and "NSHQ" wells in this study) and by the Oman Drilling Project in 2016 through 2018 ("CM") (Parsons International \& Co., 2005; P. Kelemen et al., 2013). Information on well location, construction, and water level are given in Table 1. In sampling campaigns in 2014 and 2015, a $12 \mathrm{~V}$ submersible Typhoon $\AA$ pump (Proactive Env. Products, Bradenton, FL, USA) with typical flow rates of $5 \mathrm{~L} \cdot \mathrm{min}^{-1}$ was used. This pump was used in all years of sampling at well NSHQ04 due to partial obstruction of this well. In all other sampling from 2016 onwards, a larger submersible pump (Grundfos SQ 2-85) with typical flow rates of $20 \mathrm{~L} \cdot \mathrm{min}^{-1}$ was used. The pumping depths are reported in Tables 1 and 2 . For fluids sampled in 2018, temperature, conductivity, and pH were measured using a ColeParmer PC100 


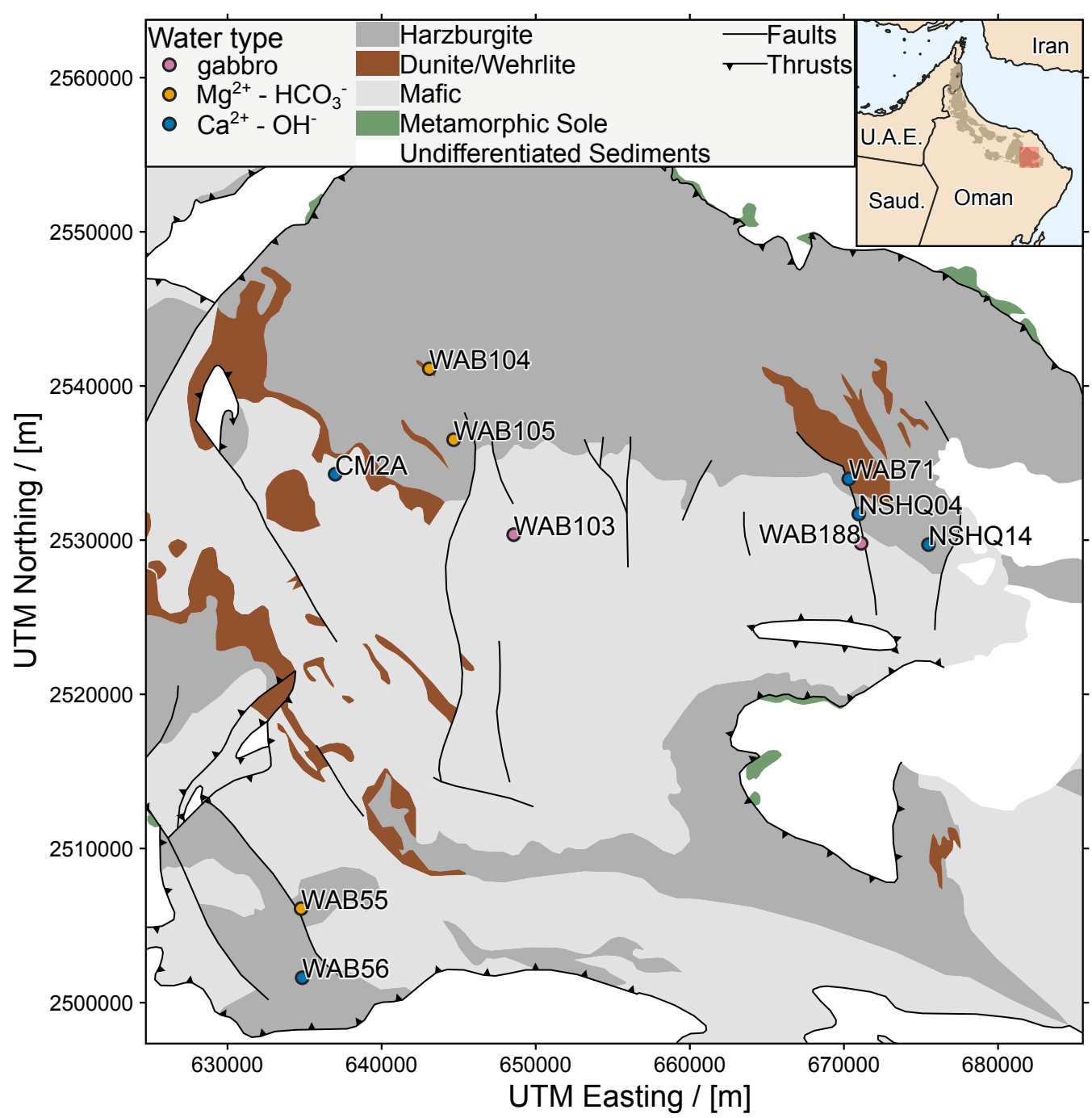

Figure 1. Study area in Samail Ophiolite, Sultanate of Oman. Geologic map data from Nicolas et al. (2000). Inset: overview of Samail Ophiolite (shaded in brown) with study area (larger map) indicated by the red shaded box. A topographic map of the study area is provided in Supporting Information Figure S1.

Meter, while Eh was measured using a Mettler Toledo SG2 SevenGo meter. The analytical uncertainties for temperature, conductivity, $\mathrm{pH}$, and $E h$ are $0.5^{\circ} \mathrm{C}, 1.0 \%$ of measured value, $0.01 \mu \mathrm{S} \cdot \mathrm{cm}^{-1}$, and $1 \mathrm{mV}$, respectively. Each well was pumped for $\geq 20 \mathrm{~min}$ prior to sampling. Sampling commenced once fluid $\mathrm{pH}$ and conductivity measurements stabilized.

\subsection{Chemical and isotopic analyses of fluids}

To analyze aqueous concentrations $(c)$ of non-carbonaceous chemical species, samples were collected by passing groundwater through a $0.2 \mu \mathrm{m}$ filter into polypropylene conical tubes. Aqueous concentrations of $\sum \mathrm{Na}, \sum \mathrm{Ca}, \sum \mathrm{Mg}, \sum \mathrm{Al}, \sum \mathrm{Fe}$, and $\sum \mathrm{Si}$ were measured by inductively coupled plasma (ICP) atomic emission spectroscopy on a PerkinElmer Optima 5300 (repeatability as median relative standard deviation of $3 \%$ ). Aqueous concentrations of $\mathrm{Cl}^{-}, \mathrm{Br}^{-}, \mathrm{F}^{-}$, and $\mathrm{SO}_{4}^{2-}$ were measured on a Dionex IC25 


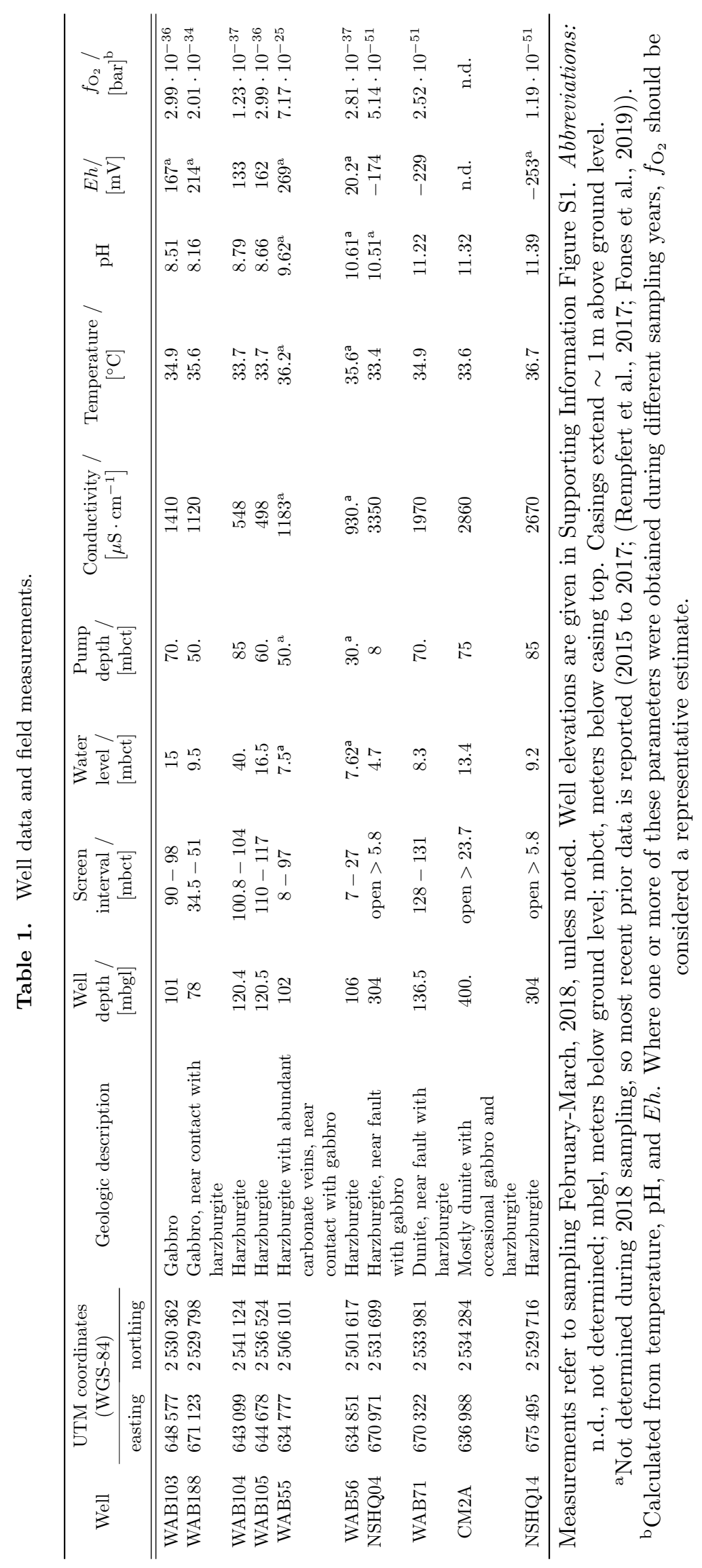


Table 2. Isotopic compositions of $\mathrm{CH}_{4}, \mathrm{C}_{2} \mathrm{H}_{6}$, and $\mathrm{C}_{3} \mathrm{H}_{8}$.

\begin{tabular}{|c|c|c|c|c|c|c|c|c|c|}
\hline Well & $\begin{array}{l}\text { Sample } \\
\text { year }\end{array}$ & $\begin{array}{l}\text { Pump depth } \\
\text { / [mbct] }\end{array}$ & laboratory & $\delta^{13} \mathrm{C}_{\mathrm{CH}_{4}}$ & $\delta \mathrm{D}_{\mathrm{CH}_{4}}$ & $\Delta^{13} \mathrm{CH}_{3} \mathrm{D}$ & $\Delta^{12} \mathrm{CH}_{2} \mathrm{D}_{2}$ & $\delta^{13} \mathrm{C}_{\mathrm{C}_{2} \mathrm{H}_{6}}$ & $\delta^{13} \mathrm{C}_{\mathrm{C}_{3} \mathrm{H}_{8}}$ \\
\hline \multirow{3}{*}{ WAB188 } & 2018 & 50. & CUB & -86.7 & n.d. & n.d. & n.d. & n.d. & n.d. \\
\hline & 2017 & 78 & CUB & -60.8 & n.d. & n.d. & n.d. & n.d. & n.d. \\
\hline & 2015 & 20. & LBNL & -71.3 & n.d. & n.d. & n.d. & n.d. & n.d. \\
\hline WAB56 & 2015 & 12 & LBNL & -83.2 & n.d. & n.d. & n.d. & n.d. & n.d. \\
\hline \multirow{4}{*}{ NSHQ04 } & 2018 & 8 & $\begin{array}{c}\text { CUB } \\
\text { UCLA }\end{array}$ & $\begin{array}{c}4.7 \\
4.177\end{array}$ & $\begin{array}{c}-229 \\
-227.396\end{array}$ & $\begin{array}{c}\text { n.d. } \\
0.229 \pm 0.288\end{array}$ & $\begin{array}{c}\text { n.d. } \\
-24.502 \pm 0.944\end{array}$ & $\begin{array}{l}\text { n.d. } \\
\text { n.d. }\end{array}$ & $\begin{array}{l}\text { n.d. } \\
\text { n.d. }\end{array}$ \\
\hline & 2017 & 5.8 & $\begin{array}{l}\text { CUB } \\
\text { MIT }\end{array}$ & $\begin{array}{c}6.8 \\
3.59\end{array}$ & $\begin{array}{c}-225 \\
-229.67\end{array}$ & $\begin{array}{c}\text { n.d. } \\
0.12 \pm 0.17\end{array}$ & $\begin{array}{l}\text { n.d. } \\
\text { n.d. }\end{array}$ & $\begin{array}{l}\text { n.d. } \\
\text { n.d. }\end{array}$ & $\begin{array}{l}\text { n.d. } \\
\text { n.d. }\end{array}$ \\
\hline & 2015 & 22 & $\begin{array}{l}\text { LBNL } \\
\text { MIT }\end{array}$ & $\begin{array}{c}0.8 \\
1.60\end{array}$ & $\begin{array}{c}-209 \\
-230.00\end{array}$ & $\begin{array}{c}\text { n.d. } \\
0.72 \pm 0.29\end{array}$ & $\begin{array}{l}\text { n.d. } \\
\text { n.d. }\end{array}$ & $\begin{array}{l}\text { n.d. } \\
\text { n.d. }\end{array}$ & $\begin{array}{l}\text { n.d. } \\
\text { n.d. }\end{array}$ \\
\hline & 2014 & 18 & LBNL & 2.4 & -205 & n.d. & n.d. & n.d. & n.d. \\
\hline \multirow{4}{*}{ WAB71 } & 2018 & 70. & CUB & 3.6 & -307 & n.d. & n.d. & n.d. & n.d. \\
\hline & 2017 & 50. & CUB & 3.9 & -313 & n.d. & n.d. & n.d. & n.d. \\
\hline & 2016 & 50. & LBNL & 3.0 & n.d. & n.d. & n.d. & n.d. & n.d. \\
\hline & 2015 & 18 & LBNL & 2.9 & n.d. & n.d. & n.d. & n.d. & n.d. \\
\hline $\mathrm{CM} 2 \mathrm{~A}$ & 2018 & 75 & $\begin{array}{c}\text { CUB } \\
\text { MIT } \\
\text { UCLA }\end{array}$ & $\begin{array}{c}-4.3 \\
-3.83 \\
-4.710 \\
\end{array}$ & $\begin{array}{c}-206 \\
-190.32 \\
-197.73\end{array}$ & $\begin{array}{c}\text { n.d. } \\
2.87 \pm 0.57 \\
2.638 \pm 0.284\end{array}$ & $\begin{array}{c}\text { n.d. } \\
\text { n.d. } \\
-1.267 \pm 0.886\end{array}$ & $\begin{array}{l}\text { n.d. } \\
\text { n.d. } \\
\text { n.d. }\end{array}$ & $\begin{array}{l}\text { n.d. } \\
\text { n.d. } \\
\text { n.d. }\end{array}$ \\
\hline \multirow{5}{*}{ NSHQ14 } & 2018 & 85 & $\begin{array}{c}\text { CUB } \\
\text { MIT } \\
\text { UCLA }\end{array}$ & $\begin{array}{c}-2.3 \\
-5.02 \\
-3.352\end{array}$ & $\begin{array}{c}-314 \\
-311.73 \\
-293.58\end{array}$ & $\begin{array}{c}\text { n.d. } \\
0.77 \pm 0.44 \\
2.074 \pm 0.298\end{array}$ & $\begin{array}{c}\text { n.d. } \\
\text { n.d. } \\
-0.204 \pm 1.358\end{array}$ & $\begin{array}{l}\text { n.d. } \\
\text { n.d. } \\
\text { n.d. }\end{array}$ & $\begin{array}{l}\text { n.d. } \\
\text { n.d. } \\
\text { n.d. }\end{array}$ \\
\hline & 2017 & 85 & $\begin{array}{l}\text { CUB } \\
\text { MIT }\end{array}$ & $\begin{array}{c}0.2 \\
-0.08\end{array}$ & $\begin{array}{c}-271 \\
-268.82\end{array}$ & $\begin{array}{c}\text { n.d. } \\
0.69 \pm 0.23\end{array}$ & $\begin{array}{l}\text { n.d. } \\
\text { n.d. }\end{array}$ & $\begin{array}{l}-6.0 \\
\text { n.d. }\end{array}$ & $\begin{array}{l}+3.3 \\
\text { n.d. }\end{array}$ \\
\hline & 2016 & 70. & $\begin{array}{l}\text { LBNL } \\
\text { MIT }\end{array}$ & $\begin{array}{c}1.8 \\
-6.89\end{array}$ & $\begin{array}{c}-273 \\
-308.52\end{array}$ & $\begin{array}{c}\text { n.d. } \\
0.69 \pm 0.17\end{array}$ & $\begin{array}{l}\text { n.d. } \\
\text { n.d. }\end{array}$ & $\begin{array}{l}\text { n.d. } \\
\text { n.d. }\end{array}$ & $\begin{array}{l}\text { n.d. } \\
\text { n.d. }\end{array}$ \\
\hline & 2015 & 20. & LBNL & 3.7 & n.d. & n.d. & n.d. & n.d. & n.d. \\
\hline & 2014 & 260. & LBNL & 3.0 & -232 & n.d. & n.d. & n.d. & n.d. \\
\hline
\end{tabular}

All isotopic values reported in $\%$ units. $\delta^{13} \mathrm{C}$ and $\delta \mathrm{D}$ reported in the VPDB and VSMOW reference frames, respectively. Data from 2014 previously reported by Miller et al. (2016). Abbreviations: n.d., not determined; mbct, meters below casing top. 
ion chromatograph with an AS9-HC IonPac column, with the exception of $\mathrm{NO}_{3}^{-}$, which was measured on a Dionex 4500I ion chromatograph with an IonPac AS14 column using EPA method 300.0 (analytical uncertainty of $2 \%$ ).

The concentration and $\delta^{13} \mathrm{C}$ of dissolved inorganic $\mathrm{C}\left(\sum \mathrm{CO}_{2}\right)$ were measured by acidification of water samples and transfer of resultant $\mathrm{CO}_{2}(\mathrm{~g})$ via a Thermo Fisher GasBench II to a Thermo Delta V Plus isotope ratio mass spectrometer. We optimized the methods of Assayag et al. (2006) for the wide range of $c_{\sum \mathrm{CO}_{2}}$ observed in ophiolite groundwaters. Complete methodological details are available in D. B. Nothaft (2019b). Sample $\delta^{13} \mathrm{C}$ values were converted to the VPDB reference frame using measured $\delta^{13} \mathrm{C}$ values of international reference materials (Harding Iceland Spar and LSVEC). Isotopic reference frame calculations were performed using the Isoverse suite of packages (Kopf et al., 2021) for the statistical programming language, R (R Core Team, 2019).

Water $\delta^{18} \mathrm{O}$ and $\delta \mathrm{D}$ were measured on a Picarro L2120-i cavity ring down spectrometer. The instrument analyzed each sample six times, excluding the first three analyses to avoid memory effects. Reported precision is the standard deviation of the last three measurements. Reported accuracy is the mean difference between accepted values and measured values of standards. Mean precision in the run was $0.06 \%$ for $\delta^{18} \mathrm{O}$ and $0.23 \%$ for $\delta \mathrm{D}$; mean accuracy was $0.04 \%$ for $\delta^{18} \mathrm{O}$ and $0.47 \%$ for $\delta \mathrm{D}$.

Gases dissolved in pumped groundwaters were sampled by injecting water into $\mathrm{N}_{2}$ purged vials for headspace gas analysis using methods described by Miller et al. (2016) in field campaigns occurring from 2014 to 2017. In addition, the bubble strip method (modified from (Kampbell et al., 1998)) was used from 2016 to 2018. Details on bubble strip gas sampling are available in D. B. Nothaft (2019a). The gas concentrations reported in this study were determined from bubble strip samples. These concentrations were measured on an SRI 8610C gas chromatograph (GC) with $\mathrm{N}_{2}$ as the carrier gas. $\mathrm{H}_{2}, \mathrm{CO}, \mathrm{CH}_{4}$, and $\mathrm{CO}_{2}$ were separated with a $2 \mathrm{~mm}$ by $1 \mathrm{~mm}$ ID micropacked ShinCarbon ST column, whereas alkanes of 2 to $6 \mathrm{C}$ atoms (" $\mathrm{C}_{2}-\mathrm{C}_{6}$ short-chain alkanes") were separated with a PORAPAK Q $6 \mathrm{ft}$ by 0.085 in ID column. Peak intensities were measured concurrently using a thermal conductivity detector (TCD) and a flame ionization detector (FID) and calibrated with standard gas mixes (Supelco Analytical, Bellefonte, PA, USA; accuracy of $\pm 2 \%$ of reported concentration). Measurement repeatability expressed as relative standard deviation was $5 \%$ over most of the calibrated range. The limit of quantitation was defined as the signal at which the relative standard deviation increased to $20 \%$. In 2018, $\mathrm{H}_{2}$ and $\mathrm{CO}$ were analyzed on a Peak Performer 1 gas chromatograph equipped with a reducing compound photometer (RCP). Due to the high sensitivity of the RCP, the signal at limit of quantitation $\left(S_{\mathrm{LQ}}\right)$ for these analyses was defined as $S_{\mathrm{LQ}}=S_{\mathrm{b}}+10 \cdot \sigma_{\mathrm{b}}$, where $S_{\mathrm{mb}}$ is the mean signal of blanks prepared in field and $\sigma_{\mathrm{b}}$ is the population standard deviation of these blanks, in accordance with American Chemical Society guidelines (MacDougall et al., 1980). Gaseous concentrations were converted to aqueous concentrations using gas solubilities (Sander, 2015) and corrected for temperature and volume changes between sampling and analysis.

Prior to 2017, bulk stable isotope analyses of $\mathrm{CH}_{4}$ were conducted at the Center for Isotope Geochemistry at the Lawrence Berkeley National Laboratory (LBNL) by gas chromatography/combustion/pyrolysis isotope-ratio mass spectrometry (GC/C/Pyr/IRMS) using methods described by Miller et al. (2016). The measurement repeatability expressed as 1 sample standard deviation $(s)$ for these analyses is $\pm 0.2 \%$ for $\delta^{13} \mathrm{C}$ and $\pm 5 \%$ for $\delta \mathrm{D}$.

From 2017 onwards, bulk stable isotope analyses of $\mathrm{CH}_{4}$ and co-occurring alkane gases were conducted at the University of Colorado - Boulder (CUB) by GC/C/Pyr/IRMS using a Trace 1310 GC equipped with an Agilent J \& W GS-CarbonPLOT column (30 m length, $0.32 \mathrm{~mm}$ ID, $3.0 \mu \mathrm{m}$ film) coupled to a Thermo Scientific MAT253 IRMS. $\mathrm{CH}_{4}$ isotope standards purchased from Airgas (uncertainties of $\pm 0.3 \%$ for $\delta^{13} \mathrm{C}$ and $\pm 5 \%$ 
for $\delta \mathrm{D}$ ) were used for calibration. Over the range of peak amplitudes of analyses reported here, the repeatability expressed as $1 s$ on analyses of standards is $\pm 0.6 \%$ for $\delta^{13} \mathrm{C}$ and $\pm 7 \%$ for $\delta \mathrm{D}$. The analytical uncertainty (accuracy) expressed as 1 standard error on a 3-point calibration was $<0.3 \%$ for $\delta^{13} \mathrm{C}$ and $<9 \%$ for $\delta \mathrm{D}$ (Supporting Information Section S1).

The relative abundances of $\mathrm{CH}_{4}$ isotopologues, including the doubly-substituted isotopologue, ${ }^{13} \mathrm{CH}_{3} \mathrm{D}$, were measured at the Massachusetts Institute of Technology (MIT) by tunable infrared laser direct absorption spectroscopy following the methods described by Ono et al. (2014). Abundances of $\mathrm{CH}_{4}$ isotopologues, including both ${ }^{13} \mathrm{CH}_{3} \mathrm{D}$ and ${ }^{12} \mathrm{CH}_{2} \mathrm{D}_{2}$, were measured at the University of California, Los Angeles (UCLA) by high-mass-resolution gas-source isotope ratio mass spectrometry following the procedure of E. D. Young et al. (2016). The abundance of ${ }^{13} \mathrm{CH}_{3} \mathrm{D}$ relative to a random (stochastic) distribution of isotopes among the isotopologues in a $\mathrm{CH}_{4}$ sample is described by its $\Delta^{13} \mathrm{CH}_{3} \mathrm{D}$ value, which is defined as: $\Delta^{13} \mathrm{CH}_{3} \mathrm{D}=\ln Q$, where $Q$ is the reaction quotient of the isotope exchange reaction:

$$
{ }^{13} \mathrm{CH}_{4}+{ }^{12} \mathrm{CH}_{3} \mathrm{D} \rightleftharpoons{ }^{12} \mathrm{CH}_{4}+{ }^{13} \mathrm{CH}_{3} \mathrm{D} \text {. }
$$

Analogous expressions can be written for doubly-deuterated $\mathrm{CH}_{4},{ }^{12} \mathrm{CH}_{2} \mathrm{D}_{2}$.

\subsection{S rRNA gene sequencing and analysis}

Biomass for DNA extraction was concentrated by pumping $5 \mathrm{~L}$ to $20 \mathrm{~L}$ of groundwater through Millipore polycarbonate inline filters $(0.45 \mu \mathrm{m}$ pore diameter, $47 \mathrm{~mm}$ filter diameter). At well NSHQ04, a $0.22 \mu \mathrm{m}$ pore diameter polyethersulfone Millipore Sterivex filter was used instead due to the lower-flow pump used at this well (Section 3.1). Filters were placed in cryovials, transported frozen in liquid $\mathrm{N}_{2}$, and stored in a $-70^{\circ} \mathrm{C}$ freezer until extraction. DNA was extracted from one quarter subsamples of each filter using a Qiagen PowerSoil DNA extraction kit. The V4 hypervariable region of the 16S rRNA gene was amplified by PCR in duplicate reactions using the 515 (Parada) - 806R (Apprill) primer pair modified to include Illumina adapters and the appropriate error-correcting barcodes. Each $25-\mu \mathrm{L}$ reaction mixture included $12.5 \mu \mathrm{L}$ of Promega HotStart Mastermix, $10.5 \mu \mathrm{L}$ of PCR-grade water, $1 \mu \mathrm{L}$ of PCR primers (combined at $10 \mu \mathrm{M}$ ), and $1 \mu \mathrm{L}$ of purified genomic DNA. PCR consisted of an initial step at $94^{\circ} \mathrm{C}$ for 3 min followed by 35 cycles of $94^{\circ} \mathrm{C}$ for $45 \mathrm{~s}, 50^{\circ} \mathrm{C}$ for $1 \mathrm{~min}$, and $72^{\circ} \mathrm{C}$ for $1.5 \mathrm{~min}$. PCR concluded with a final elongation step at $72{ }^{\circ} \mathrm{C}$ for $10 \mathrm{~min}$. No-template controls and DNA extraction controls were subjected to PCR to check for potential contamination in our PCR and DNA extraction reagents, respectively. Amplification was evaluated via electrophoresis in a $2 \%$ agar gel. Amplicons from duplicate reactions were pooled, cleaned, and their concentrations normalized using a Thermo Fisher SequalPrep normalization plate kit. Amplicons were sequenced on an Illumina MiSeq at the CUB Next-Generation Sequencing Facility with 2-by-150 bp paired-end chemistry.

Sequences were demultiplexed with idemp (Wu, 2017). The resultant fastq files were quality filtered using Figaro v1.1.1 (Weinstein, 2019) and the DADA2 v1.16 R package (Callahan et al., 2016). Amplicon sequence variants were assigned taxonomy to the genus level using the RDP classifier (Q. Wang et al., 2007) trained on the Silva SSU 138 reference database (Quast et al., 2012) using the DADA2 assignTaxonomy function. Species level assignments were based on exact matching between amplicon sequence variants and sequenced reference strains using the DADA2 addSpecies function. Sequences assigned to mitochondria, chloroplast, and Eukaryota, or not assigned at the domain level (collectively $<1 \%$ of sequences), were removed. After all of the above filtering, 24000 to 40000 reads per sample remained for the samples presented here obtained in 2018. In addition, 16S rRNA gene sequencing data from previous Oman sampling campaigns (2014 through 2017; (Miller et al., 2016; Rempfert et al., 2017; Kraus et al., 2021)) were re- 
processed in accordance with the methods outlined here to facilitate comparisons across the data sets. The complete data processing pipeline for samples across all years, from raw data provided by the sequencing facility through to taxonomic assignment, are available in D. B. Nothaft, Rempfert, and Kraus (2021). Additional analyses and plotting can be found in D. B. Nothaft, Templeton, et al. (2021). For samples presented in this study, demultiplexed fastq files (without additional processing) are also accessible on the NCBI Short Read Archive under accession PRJNA655565.

\subsection{Thermodynamic calculations}

Oxidation-reduction potential, $\mathrm{pH}$, and concentrations of major ions and $\sum \mathrm{CO}_{2}$ were used as inputs for the modeling software PHREEQC (Charlton \& Parkhurst, 2011; Parkhurst \& Appelo, 2013), with which fluids were speciated using the LLNL database. Activities of formate and acetate were separately calculated according to the Debye-Hückel equation. Activities of the aqueous gases were assumed equivalent to their concentrations, which is reasonable for neutral species in low ionic strength solutions. Standard Gibbs free energies $\left(\Delta \mathrm{G}_{r}^{\circ}\right.$ ) of the $\mathrm{CH}_{4}$-forming reactions were calculated using the program SUPCRTBL (Johnson et al., 1992; Zimmer et al., 2016) using conditions of 1 bar and $35^{\circ} \mathrm{C}$ to approximate in situ conditions. Gibbs free energies were then calculated as $\Delta G_{r}=\Delta G_{r}^{\circ}+R T \ln Q_{r}$, where $R$ is the universal gas constant, $T$ is temperature, and $Q_{r}$ is the reaction quotient. All of the above calculations and software inputs and outputs can be found in D. B. Nothaft, Templeton, et al. (2021).

\section{Results and discussion}

\subsection{Controls on groundwater chemistry}

To assess the source and reaction histories of Samail Ophiolite groundwaters, we measured their stable isotopic compositions and solute concentrations. Groundwater $\delta \mathrm{D}$ and $\delta^{18} \mathrm{O}$ plotted near local and global meteoric water lines (Weyhenmeyer et al., 2002; Terzer et al., 2013), indicating that the groundwaters derive from rain (Table 3; Supporting Information Figure S2; (Matter et al., 2006; Miller et al., 2016; Paukert Vankeuren et al., 2019)). The sampled groundwaters included oxidized and moderately alkaline $\mathrm{Mg}^{2+}-$ $\mathrm{HCO}_{3}^{-}$waters, typical of reaction with peridotite in communication with the atmosphere, and reduced and hyperalkaline $\mathrm{Ca}^{2+}-\mathrm{OH}^{-}$waters, typical of extensive hydration and oxidation of peridotite in closed-system conditions with respect to the atmosphere (Table 3; (Barnes et al., 1967; Barnes \& O’Neil, 1969; Neal \& Stanger, 1985; Bruni et al., 2002; Cipolli et al., 2004; P. B. Kelemen et al., 2011; A. N. Paukert et al., 2012)). $\mathrm{Ca}^{2+}$ $\mathrm{OH}^{-}$waters had higher conductivities $\left(930 . \mu \mathrm{S} \cdot \mathrm{cm}^{-1}\right.$ to $\left.3350 \mu \mathrm{S} \cdot \mathrm{cm}^{-1}\right)$ than $\mathrm{Mg}^{2+}$ $\mathrm{HCO}_{3}^{-}$waters $\left(498 \mu \mathrm{S} \cdot \mathrm{cm}^{-1}\right.$ to $\left.1183 \mu \mathrm{S} \cdot \mathrm{cm}^{-1}\right)$ (Table 1$)$. The increase in conductivity from $\mathrm{Mg}^{2+}-\mathrm{HCO}_{3}^{-}$waters to $\mathrm{Ca}^{2+}-\mathrm{OH}^{-}$waters is driven by enrichments in $\mathrm{Ca}^{2+}$ derived from dissolution of primary silicate minerals in addition to $\mathrm{Na}^{+}$and $\mathrm{Cl}^{-}$derived from mineral dissolution, sea spray, and/or leaching of sea salts introduced during subseafloor alteration and/or ophiolite emplacement (Neal \& Stanger, 1985; Stanger, 1986; Murad \& Krishnamurthy, 2004; A. N. Paukert et al., 2012; Rempfert et al., 2017). The increase in $\mathrm{pH}$ from $\mathrm{Mg}^{2+}-\mathrm{HCO}_{3}^{-}$waters $\left(\mathrm{pH} 8.66\right.$ to 9.62) to $\mathrm{Ca}^{2+}-\mathrm{OH}^{-}$waters (10.51 to 11.39$)$ was accompanied by a shift to lower $f_{\mathrm{O}_{2}}$ and $E h\left(\sim 10^{-51}\right.$ bar and $-174 \mathrm{mV}$ to $-253 \mathrm{mV}$, respectively, in most $\mathrm{Ca}^{2+}-\mathrm{OH}^{-}$waters) (Table 1 ), indicating reduced conditions in $\mathrm{Ca}^{2+}-\mathrm{OH}^{-}$waters.

Concentrations of $\sum \mathrm{CO}_{2}$ were relatively high in $\mathrm{Mg}^{2+}-\mathrm{HCO}_{3}^{-}$waters and gabbro waters (up to $3490 \mu \mathrm{mol} \cdot \mathrm{L}^{-1}$ ), but below the limit of quantitation $(<12 \mu \mathrm{mol}$. $\mathrm{L}^{-1}$ ) in most $\mathrm{Ca}^{2+}-\mathrm{OH}^{-}$waters (Table 3 ). This is consistent with water-harzburgite reaction path modeling that terminates at chrysotile-brucite-diopside-calcite equilibrium, corresponding to a $c_{\sum \mathrm{CO}_{2}}$ of $8 \mu \mathrm{mol} \cdot \mathrm{L}^{-1}$ at $25^{\circ} \mathrm{C}$ and 1 bar (Leong \& Shock, 2020). 


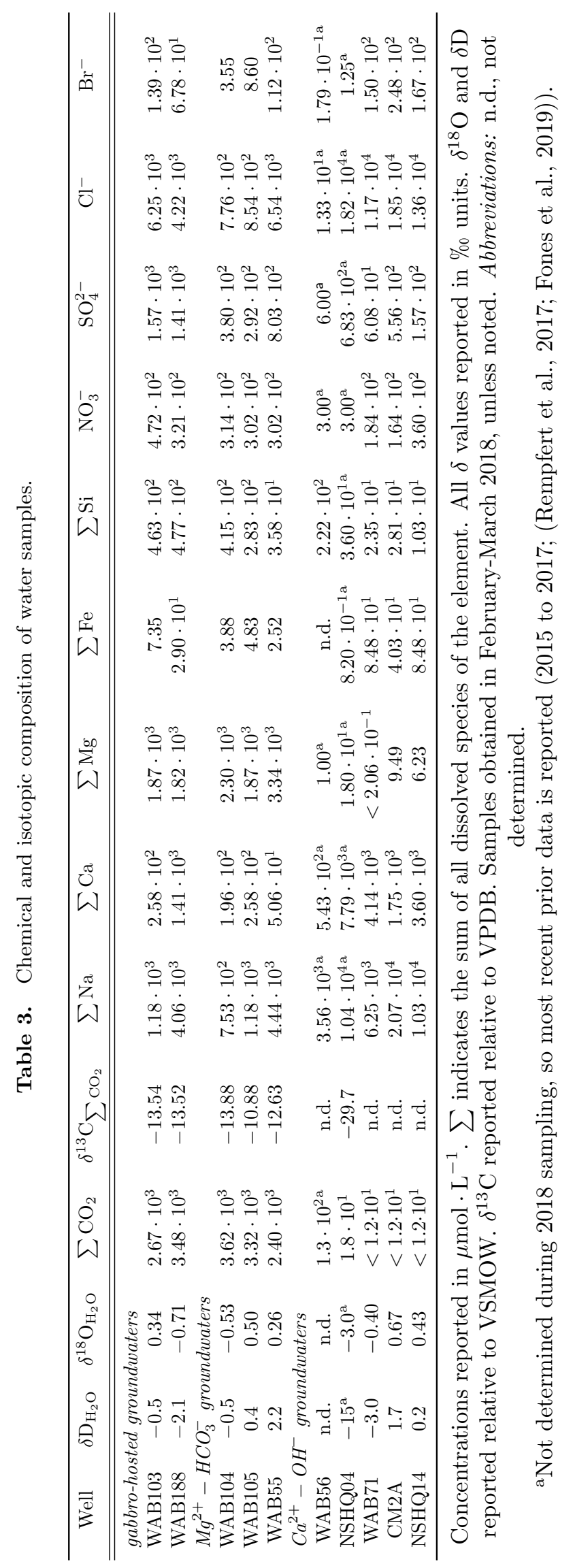


Literature values for ${ }^{c} \sum \mathrm{CO}_{2}$ in ophiolitic $\mathrm{Ca}^{2+}-\mathrm{OH}^{-}$waters are often higher than those predicted by reaction path modeling, but the lower range of reported values approaches $1 \mu \mathrm{mol} \cdot \mathrm{L}^{-1}$ (Barnes et al., 1967; Barnes \& O'Neil, 1969; Barnes et al., 1978; Neal \& Stanger, 1985; Bruni et al., 2002; Cipolli et al., 2004; A. N. Paukert et al., 2012; Falk et al., 2016; Brazelton et al., 2017; Canovas III et al., 2017; Crespo-Medina et al., 2017; Rempfert et al., 2017; Fones et al., 2019; Paukert Vankeuren et al., 2019). This spread in the data could reflect groundwater mixing, atmospheric contamination during sampling, differences in reaction temperature and progress, and/or kinetic inhibitions to carbonate mineral precipitation. In $\mathrm{Mg}^{2+}-\mathrm{HCO}_{3}^{-}$waters and waters from gabbroic aquifers, $\delta^{13} \mathrm{C}_{\sum \mathrm{CO}_{2}}$ ranged from $-13.54 \%$ VPDB to $-10.88 \%$ VPDB (Table 3), which is comparable to $\delta^{13} \mathrm{C}_{\sum \mathrm{CO}_{2}}$ of $\mathrm{Mg}^{2+}-\mathrm{HCO}_{3}^{-}$waters elsewhere in the ophiolite $(-15.56 \%$ VPDB to $-13.60 \%$ VPDB; (Matter et al., 2006; D. Nothaft et al., 2021)).

Variable concentrations of $\mathrm{H}_{2}$ and $\mathrm{CH}_{4}$ across wells suggest spatial heterogeneities in sources and sinks of these gases in the ophiolite. In some $\mathrm{Ca}^{2+}-\mathrm{OH}^{-}$waters, $c_{\mathrm{H}_{2}}$ was high (up to $253 \mu \mathrm{mol} \cdot \mathrm{L}^{-1}$ ), but $c_{\mathrm{H}_{2}}$ was below limits of quantitation in other $\mathrm{Ca}^{2+}$ $\mathrm{OH}^{-}$waters (Figure 2; Table 4). In $\mathrm{Mg}^{2+}-\mathrm{HCO}_{3}^{-}$waters and waters from gabbroic aquifers, $c_{\mathrm{H}_{2}}$ was generally below limits of quantitation. However, up to $0.992 \mu \mathrm{mol} \cdot \mathrm{L}^{-1}$ $\mathrm{H}_{2}$ was measured in well WAB188, which is in gabbro near a faulted contact with peridotites that contain $\mathrm{Ca}^{2+}-\mathrm{OH}^{-}$waters (Figure 1; Table 1). This suggests production of $\mathrm{H}_{2}$ within the gabbro host rock or migration of $\mathrm{H}_{2}$ from peridotites into gabbros surrounding WAB188. In most $\mathrm{Ca}^{2+}-\mathrm{OH}^{-}$waters, $c_{\mathrm{CH}_{4}}$ was high (up to $483 \mu \mathrm{mol} \cdot \mathrm{L}^{-1}$; Figure 2, Table 4). However, wells with high $c_{\mathrm{CH}_{4}}$ did not always have high $c_{\mathrm{H}_{2}}$ (Figure 2; Table 4). In $\mathrm{Mg}^{2+}-\mathrm{HCO}_{3}^{-}$waters and gabbro waters, $c_{\mathrm{CH}_{4}}$ was typically lower $\left(\leq 0.1 \mu \mathrm{mol} \cdot \mathrm{L}^{-1}\right)$, although $c_{\mathrm{CH}_{4}}$ reached $1.83 \mu \mathrm{mol} \cdot \mathrm{L}^{-1}$ in well WAB188, where $c_{\mathrm{H}_{2}}$ was also quantitatable.

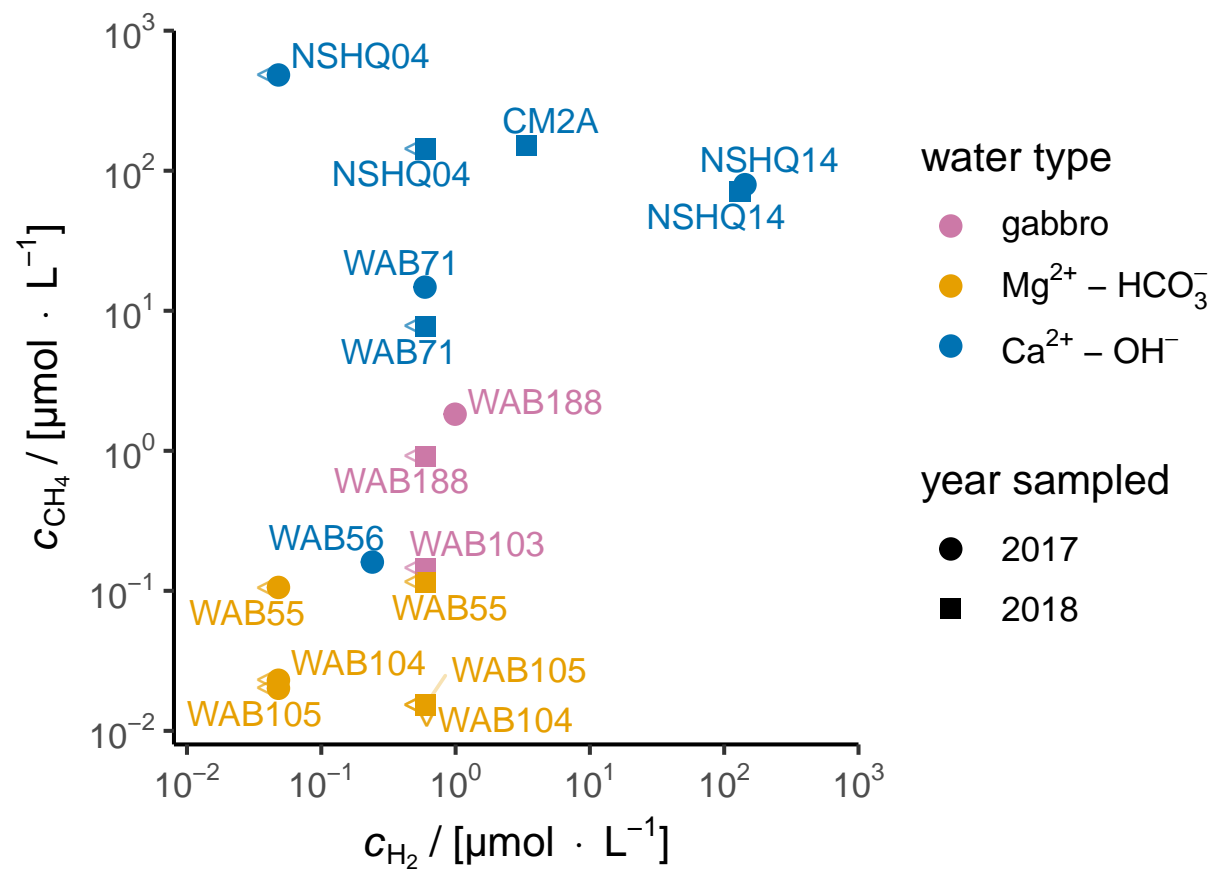

Figure 2. Aqueous concentrations of $\mathrm{CH}_{4}$ and $\mathrm{H}_{2}$ in Oman groundwater samples from 2017 and 2018. Left and down carrots denote "below limit of quantitation" for $\mathrm{CH}_{4}$ and $\mathrm{H}_{2}$, respectively, with the adjacent point plotted at the limit of quantitation for that gas and year of analysis. 


\subsection{Origin of $\mathrm{CH}_{4}$ and co-occurring short-chain alkanes in the Samail Ophiolite}

We begin our examination of $\mathrm{CH}_{4}$ origin in the Samail Ophiolite by calculating Gibbs free energies $\left(\Delta G_{r}\right)$ of potential $\mathrm{CH}_{4}$-forming reactions under relevant environmental conditions and discussing these results in light of recent microbiological studies on methanogenesis in the study area. Subsequent discussion focuses on fluid and particulate samples from a subset of wells (NSHQ14, NSHQ04, and WAB188) that yielded particularly rich data sets from which we infer key $\mathrm{CH}_{4}$ cycle processes. Discussion of three additional wells (WAB71, WAB56, and CM2A) in Supporting Information Text S1 illustrates that the processes outlined below occur throughout the broader study area with some variation due to local hydrogeologic factors.

\subsubsection{Assessing which $\mathrm{CH}_{4}$-forming reactions might occur using ther- modynamic and microbiological data}

To assess which $\mathrm{CH}_{4}$-forming aqueous reactions might occur within the Samail Ophiolite, $\Delta G_{r}$ 's were calculated for the following reactions:

$$
\left.\mathrm{CO}_{2}(\mathrm{aq})+4 \mathrm{H}_{2}(\mathrm{aq})=\mathrm{CH}_{4}(\mathrm{aq})+2 \mathrm{H}_{2} \mathrm{O}(\mathrm{l}) \text { (hydrogenotrophic methanogenesis }\right)
$$

$$
\mathrm{CH}_{3} \mathrm{COO}^{-}(\mathrm{aq})+\mathrm{H}^{+}(\mathrm{aq})=\mathrm{CH}_{4}(\mathrm{aq})+\mathrm{CO}_{2}(\mathrm{aq})(\text { acetoclastic methanogenesis })
$$

$$
4 \mathrm{HCOO}^{-}(\mathrm{aq})+4 \mathrm{H}^{+}(\mathrm{aq})=\mathrm{CH}_{4}(\mathrm{aq})+3 \mathrm{CO}_{2}(\mathrm{aq})+2 \mathrm{H}_{2} \mathrm{O}(\mathrm{l}) \text { (formatotrophic methanogenesis) }
$$

Gas-phase, abiotic reactions are also possible (Etiope \& Ionescu, 2015; Etiope et al., 2018), but measurements of partial pressures of relevant gases in unsaturated zones of the subsurface in the study area are absent. Thus, $\Delta G_{r}$ 's of gas-phase reactions were not calculated. In addition to the common hydrogenotrophic and acetoclastic modes of methanogenesis, formatotrophic methanogenesis (Equation 4) was considered because formate can be produced abiotically in serpentinizing settings (McCollom \& Seewald, 2003; McDermott et al., 2015; Miller, Mayhew, et al., 2017) and has been suggested as an important substrate for microbial metabolism in these settings (Lang et al., 2018), including for methanogenesis (Fones et al., 2020).

Rather than calculate $\Delta G_{r}$ 's of the above reactions for each individual groundwater chemical analysis, we investigate a range of generalized cases to highlight the most important factors controlling $\Delta G_{r}$ 's and to assess energetic states of the system that lay beyond our analytical limits. For instance, $\sum \mathrm{CO}_{2}$ was below the limit of quantitation for the majority of the $\mathrm{Ca}^{2+}-\mathrm{OH}^{-}$groundwaters sampled in $2018\left(<12 \mu \mathrm{mol} \cdot \mathrm{L}^{-1}\right.$; Table 3). $\mathrm{H}_{2}$ was also below the limit of quantitation for several $\mathrm{Ca}^{2+}-\mathrm{OH}^{-}$and $\mathrm{Mg}^{2+}-$ $\mathrm{HCO}_{3}^{-}$groundwaters $\left(<0.048 \mathrm{nmol} \cdot \mathrm{L}^{-1}\right.$ in 2017 and $<0.598 \mathrm{nmol} \cdot \mathrm{L}^{-1}$ in 2018 ; Table 4). Further, formate and acetate were not measured explicitly for this study, but were measured on groundwaters from the studied wells sampled in 2015 (Rempfert et al., 2017). Thus, while robust constraints on the above parameters are available for the study area, complete sets of these parameters were generally not directly or simultaneously measured.

In light of this, we considered a representative $\mathrm{Mg}^{2+}-\mathrm{HCO}_{3}^{-}$groundwater and a representative $\mathrm{Ca}^{2+}-\mathrm{OH}^{-}$groundwater, made informed assumptions when direct con- 


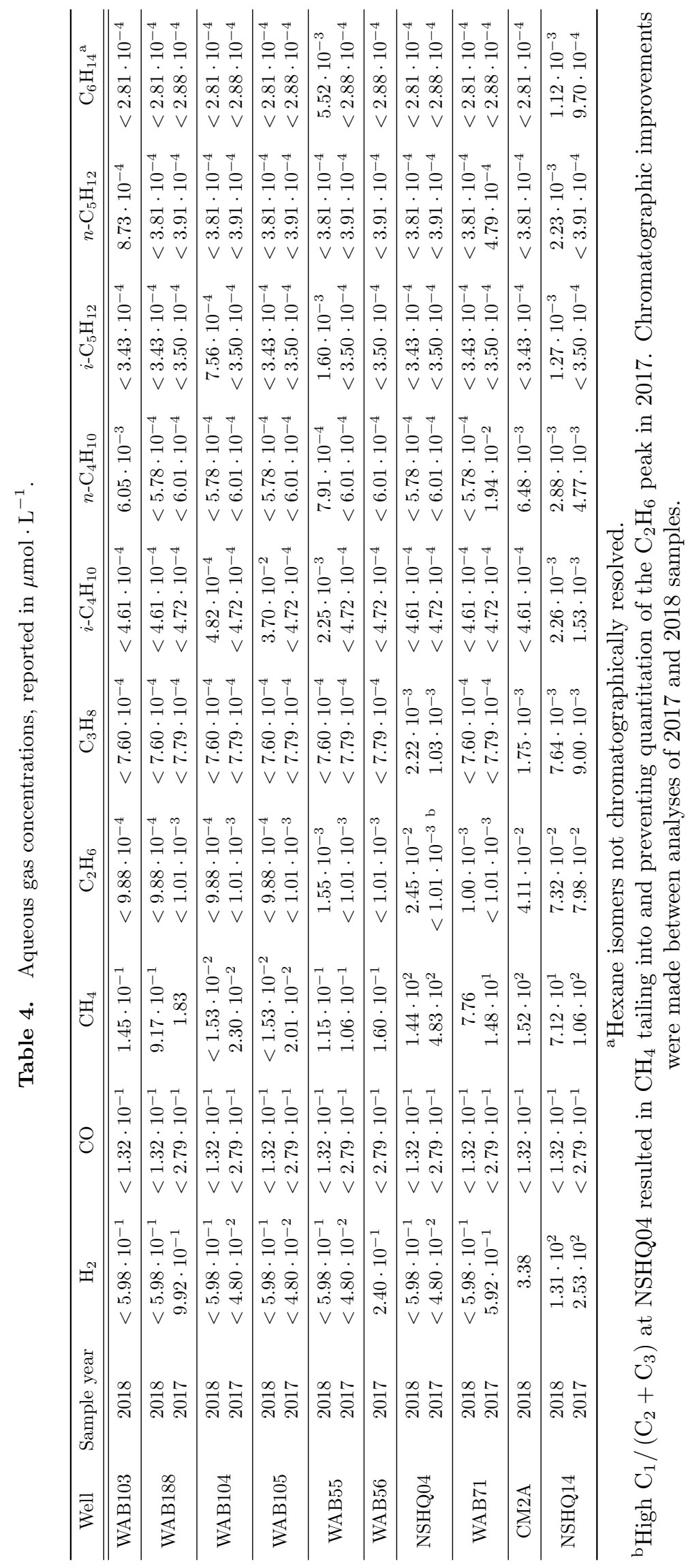


Table 5. Gibbs free energies of potential $\mathrm{CH}_{4}$-forming reactions and log activities of relevant species. Abbreviations: H, hydrogenotrophic (Equation 2); A, acetoclastic (Equation 3); F, formatotrophic methanogenesis (Equation 4).

\begin{tabular}{|c|c|c|c|c|c|c|c|c|c|}
\hline \multirow[b]{2}{*}{ water type } & \multicolumn{6}{|c|}{$\log$ (activity) } & \multicolumn{3}{|c|}{$\Delta G_{r} /\left[\mathrm{kJ} \cdot \mathrm{mol}^{-1}\right]$} \\
\hline & $\mathrm{H}^{+}$ & $\mathrm{CO}_{2}(\mathrm{aq})$ & $\mathrm{HCOO}^{-}$ & $\mathrm{CH}_{3} \mathrm{COO}^{-}$ & $\mathrm{CH}_{4}(\mathrm{aq})$ & $\mathrm{H}_{2}(\mathrm{aq})$ & $\mathrm{H}$ & A & $\mathrm{F}$ \\
\hline $\mathrm{Ca}^{2+}-\mathrm{OH}^{-}$ & -11.1 & -11.6 & -6.1 & -6.1 & -4.0 & $\begin{array}{l}-9.0 \\
-6.0 \\
-3.0\end{array}$ & $\begin{array}{c}64 \\
-6 \\
-77\end{array}$ & $\begin{array}{l}-115 \\
-115 \\
-115\end{array}$ & $\begin{array}{l}-90 \\
-90 \\
-90\end{array}$ \\
\hline $\mathrm{Mg}^{2+}-\mathrm{HCO}_{3}^{-}$ & -8.7 & -4.9 & -6.0 & -6.0 & -7.0 & $\begin{array}{l}-9.0 \\
-6.0\end{array}$ & $\begin{array}{c}8 \\
-63\end{array}$ & $\begin{array}{l}-107 \\
-107\end{array}$ & $\begin{array}{l}-47 \\
-47\end{array}$ \\
\hline
\end{tabular}

centration measurements were lacking, and evaluated $\Delta G_{r}$ 's for a range of $\mathrm{H}_{2}$ concentrations. Measurements of major inorganic dissolved constituents, $\mathrm{pH}$, and $E h$ from wells WAB105 and NSHQ14 were used for the model $\mathrm{Mg}^{2+}-\mathrm{HCO}_{3}^{-}$and $\mathrm{Ca}^{2+}-\mathrm{OH}^{-} \mathrm{flu}-$ ids, respectively (Tables 1 and 3). Since measured $c \sum_{\mathrm{CO}_{2}}$ was below the limit of quantitation in the water sample from NSHQ14, $8 \mu \mathrm{mol} \cdot \mathrm{kg}^{-1}$ was taken as the ${ }^{c} \sum \mathrm{CO}_{2}$ of the representative $\mathrm{Ca}^{2+}-\mathrm{OH}^{-}$water, corresponding to the value at chrysotile-brucitediopside-calcite equilibrium at $25^{\circ} \mathrm{C}$ and 1 bar obtained from water-harzburgite reaction path modeling (Leong \& Shock, 2020). Concentrations of formate and acetate were both assumed to be $1 \mu \mathrm{mol} \cdot \mathrm{kg}^{-1}$, which is consistent with their concentrations in earlier samples from wells in Samail Ophiolite (Rempfert et al., 2017). Concentrations of $\mathrm{CH}_{4}$ were assumed to be $100 \mu \mathrm{mol} \cdot \mathrm{kg}^{-1}$ and $0.1 \mu \mathrm{mol} \cdot \mathrm{kg}^{-1}$ for the representative $\mathrm{Ca}^{2+}-\mathrm{OH}^{-}$ and $\mathrm{Mg}^{2+}-\mathrm{HCO}_{3}^{-}$waters, respectively, reflecting typical concentrations for these fluids (Table 4, Figure 2). $\mathrm{H}_{2}$ concentrations vary widely between and within fluid types (Table 4, Figure 2), so calculations were performed for multiple $\mathrm{H}_{2}$ concentrations $\left(1 \mathrm{mmol} \cdot \mathrm{kg}^{-1}\right.$, $1 \mu \mathrm{mol} \cdot \mathrm{kg}^{-1}$, and $\left.1 \mathrm{nmol} \cdot \mathrm{kg}^{-1}\right)$ encompassing the range of concentrations observed in $\mathrm{Ca}^{2+}-$ $\mathrm{OH}^{-}$fluids. The $1 \mathrm{mmol} \cdot \mathrm{kg}^{-1} \mathrm{H}_{2}$ case was omitted for the $\mathrm{Mg}^{2+}-\mathrm{HCO}_{3}^{-}$fluid, where such high $\mathrm{H}_{2}$ concentrations are not observed. The log activities $(a)$ of all relevant species are tabulated in Table 5 .

The calculated $\Delta G_{r}$ 's (Table 5) indicate that all of the $\mathrm{CH}_{4}$-forming reactions considered here can have sufficient chemical potential to sustain microbial life in certain states of the system. That is, $\Delta G_{r}>\Delta G_{\min }$, where $\Delta G_{\min }$ (also known as the Biological Energy Quantum) is the minimum free energy that must be available to sustain life in a given environment (thought to be around $-9 \mathrm{~kJ} \cdot \mathrm{mol}^{-1}$ to $-20 \mathrm{~kJ} \cdot \mathrm{mol}^{-1}$; (Schink, 1997; Hoehler, 2004; Schink \& Stams, 2006)). Acetoclastic methanogenesis had the most negative $\Delta G_{r}$ in all conditions tested. formatotrophic methanogenesis had more negative $\Delta G_{r}$ than hydrogenotrophic methanogenesis in all $\mathrm{Ca}^{2+}-\mathrm{OH}^{-}$conditions tested, but formatotrophic methanogenesis had less negative $\Delta G_{r}$ than hydrogenotrophic methanogenesis in the $\mathrm{Mg}^{2+}-\mathrm{HCO}_{3}^{-}$case at $1 \mu \mathrm{mol} \cdot \mathrm{kg}^{-1} \mathrm{H}_{2}$. Hydrogenotrophic methanogenesis had sufficient chemical potential to sustain microbial life only when $a_{\mathrm{H}_{2}}$ was high enough, with the threshold $a_{\mathrm{H}_{2}}$ being higher in $\mathrm{Ca}^{2+}-\mathrm{OH}^{-}$waters, where $a_{\mathrm{CO}_{2}(\mathrm{aq})}$ is lower. These calculations are generally consistent with those of Canovas III et al. (2017), who found that hydrogenotrophic methanogenesis had modest potential energy yields in waters from surface seeps in the Samail Ophiolite at $\mathrm{pH}$ ranging from 8 to 12 .

Several additional factors should be considered when interpreting the $\Delta G_{r}$ results. First, reactions proceeding in environmental systems are often drawn towards equilibrium, and thus a large negative $\Delta G_{r}$ of a given reaction may indicate that that reaction is not actively occuring, but only has the potential to occur. Second, substrate transport into the cell is not addressed in our calculations. A more complete model would account for rates of $\mathrm{CO}_{2}$ diffusion across the cell membrane and/or energy expended to 
transport charged species such as formate and acetate into the cell (Hoehler, 2004). Third, mixing is not explicitly accounted for in our calculations. Mixing has been suggested as a key factor controlling energetic favorability of various reactions in the Samail Ophiolite. This is especially pertinent to hydrogenotrophic methanogenesis because $c_{\mathrm{CO}_{2}}$ is so much lower in endmember hyperalkaline fluids than in near-surface, atmosphere-influenced fluids (Canovas III et al., 2017; Leong \& Shock, 2020). The $c_{\mathrm{CO}_{2}}$ used for the example $\mathrm{Ca}^{2+}-\mathrm{OH}^{-}$fluid in our calculations is representative of a minimum value for the system (Leong \& Shock, 2020). Mixing would tend to inject $\mathrm{CO}_{2}$ into the fluids and increase the energetic favorability of hydrogenotrophic methanogenesis.

In addition to energetic considerations, microbiological approaches can help elucidate which $\mathrm{CH}_{4}$-forming reactions occur. Kraus et al. (2021) found higher transcript abundances of carbonic anhydrase and formate dehydrogenase relative to acetate kinase and phosphate acetyltransferase in hyperalkaline groundwaters from wells in the Samail Ophiolite, suggesting that $\mathrm{CO}_{2} / \mathrm{HCO}_{3}^{-}$and formate are more actively used substrates for methanogenesis than acetate in these conditions. Further, Fones et al. (2020) identified two lineages of Methanobacterium in Samail Ophiolite groundwaters that were shown by genomic and microcosm-based radiotracer approaches to use different methanogenic pathways. Methanobacterium Type I lineage predominated in circumneutral waters and is capable of using either $\mathrm{CO}_{2}$ or formate for methanogenesis. Methanobacterium Type II lineage, which was more abundant in hyperalkaline waters and which branched from the Type I lineage, was exclusively capable of formatotrophic methanogenesis. It was postulated that gene loss and acquisition in Type II lineage allowed it to be specially suited to the high-pH and low- $\sum \mathrm{CO}_{2}$ conditions resulting from extensive serpentinization. Thus, microbiological data suggest that hydrogenotrophic or formatotrophic methanogenesis are the most likely pathways for methanogenesis in the Samail Ophiolite and that the relative contributions of each of these pathways to microbial $\mathrm{CH}_{4}$ production at a given site may depend on local geochemical factors such as $a_{\mathrm{CO}_{2}(\mathrm{aq})}$. This notion is generally supported by our calculations in that formatotrophic methanogenesis had more negative $\Delta G_{r}$ than hydrogenotrophic methanogenesis in all $\mathrm{Ca}^{2+}-\mathrm{OH}^{-}$conditions tested, whereas the reverse was true for the $\mathrm{Mg}^{2+}-\mathrm{HCO}_{3}^{-}$case at $1 \mu \mathrm{mol} \cdot \mathrm{kg}^{-1} \mathrm{H}_{2}$.

Remarkably, although acetoclastic methanogenesis had the most negative $\Delta G_{r}$ of the investigated $\mathrm{CH}_{4}$-forming reactions (Table 5), it has the least microbiological evidence of being a major methanogenic pathway in the Samail Ophiolite. Conversion of isotopically labeled acetate $\left({ }^{13} \mathrm{CH}_{3} \mathrm{OO}^{-}\right)$to ${ }^{13} \mathrm{CH}_{4}$, has, however, been documented in cultures from serpentinite springs in the Voltri Massif, Italy (Brazelton et al., 2017), indicating that acetoclastic methanogenesis can operate in some serpentinizing settings. In the aquifers sampled via wells in the Samail Ophiolite, methanogens may be out-competed for acquisition of acetate by other groups of microbes, such as sulfate reducers. Indeed, geochemical evidence of microbial acetate oxidation coupled to sulfate reduction has been reported in alkaline, $\mathrm{H}_{2}$-rich, crystalline rock aquifers inhabited by microbial communities dominated by sulfate reducing bacteria and methanogens (Moser et al., 2005).

\subsubsection{Abiotic, ${ }^{13} \mathrm{C}$-enriched $\mathrm{CH}_{4}, \mathrm{C}_{2} \mathrm{H}_{6}$, and $\mathrm{C}_{3} \mathrm{H}_{8}$ mixed with micro- bial $\mathrm{CH}_{4}$ produced under $\mathrm{C}$-limited conditions in the $\mathrm{Ca}^{2+}-\mathrm{OH}^{-}$ waters of well NSHQ14}

Well NSHQ14 is situated in a catchment dominated by partially serpentinized harzburgite with meter-scale partially serpentinized dunite bands (Figure 1; Supporting Information Figure S1; Table 1). The well is cased to 5.8 meters below ground level (mbgl) and drilled to $304 \mathrm{mbgl}$ (Table 1). Groundwaters accessed via NSHQ14 had the highest $\mathrm{pH}(11.39)$, and lowest $E h(-253 \mathrm{mV})$ and $f_{\mathrm{O}_{2}}\left(1.19 \cdot 10^{-51}\right.$ bar $)$ among the wells investigated (Table 1), indicating that fluids sampled from NSHQ14 have extensively participated in serpentinization. This is also reflected in the $c_{\mathrm{H}_{2}}$ of groundwaters sampled at NSHQ14, which was the highest among the studied wells $\left(253 \mu \mathrm{mol} \cdot \mathrm{L}^{-1}\right.$ and $131 \mu \mathrm{mol}$. 

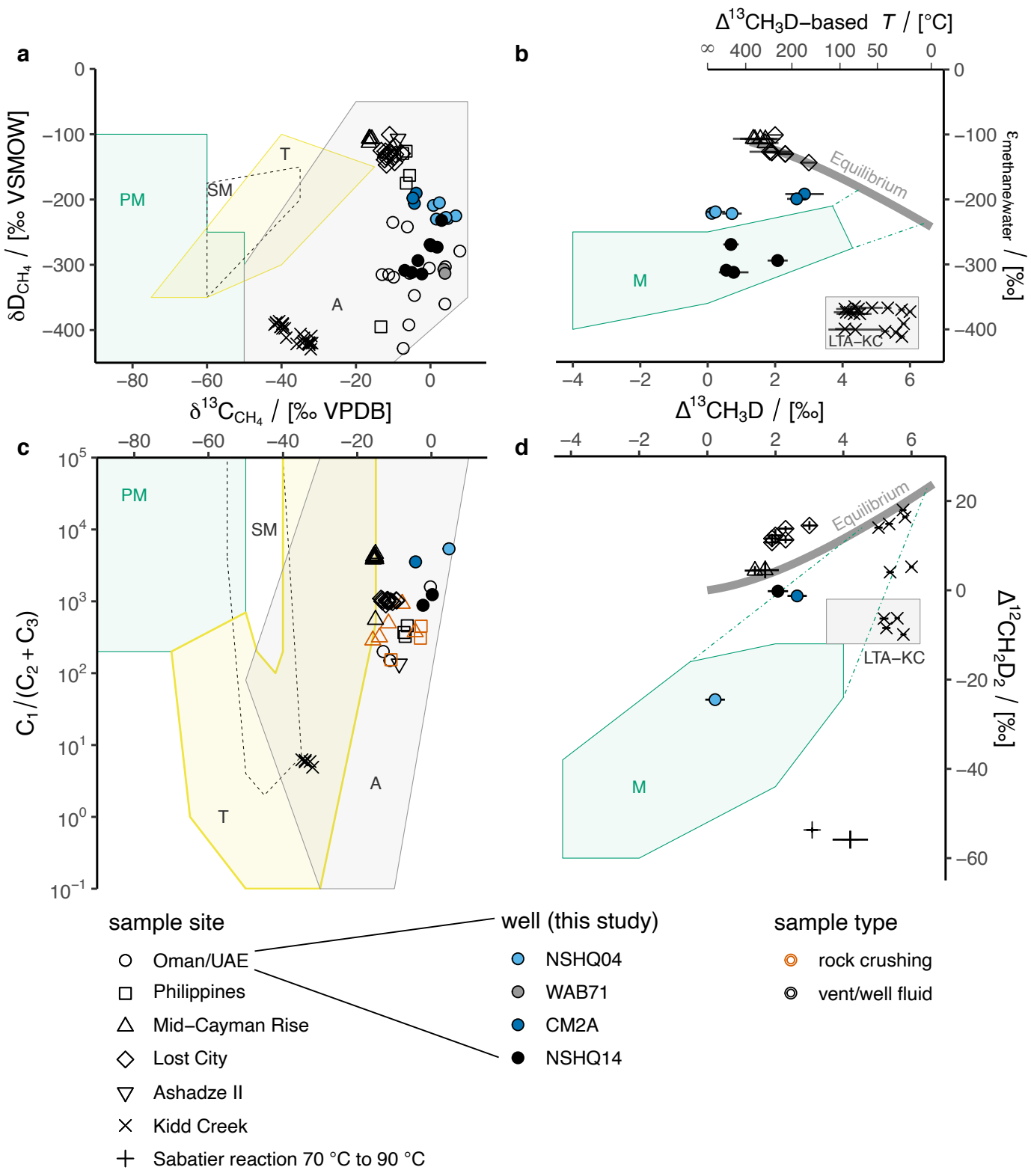

sample type

- rock crushing (-) vent/well fluid

$\triangle$ Mid-Cayman Rise

$\mathrm{L}^{-1}$ in 2017 and 2018, respectively; Table 4; Figure 2). NSHQ14 waters also had high $c_{\mathrm{CH}_{4}}\left(106 \mu \mathrm{mol} \cdot \mathrm{L}^{-1}\right.$ and $71.2 \mu \mathrm{mol} \cdot \mathrm{L}^{-1}$ in 2017 and 2018 , respectively).

$\mathrm{CH}_{4}$ has ranged in $\delta^{13} \mathrm{C}$ from $-6.89 \%$ VPDB to $+3.7 \%$ VPDB in fluid samples from NSHQ14, with a mean weighted by sample year of $-0.8 \%$ VPDB (Figure 3a; Table 2). These $\delta^{13} \mathrm{C}$ values are generally higher than those of $\mathrm{CH}_{4}$ emanating from sedimentpoor seafloor hydrothermal vents, where a dominantly abiotic origin has been proposed ((Welhan \& Craig, 1983; Merlivat et al., 1987; J. L. Charlou et al., 1996; J. Charlou et al., 2000, 2002; Proskurowski et al., 2008; Kumagai et al., 2008; McDermott et al., 2015; D. T. Wang et al., 2018); represented by Mid-Cayman Rise, Lost City, and Ashadze II in Figure 3a), higher than typical mantle values (Deines, 2002), and similar to marine carbonate (Schidlowski, 2001). $\mathrm{CH}_{4} \delta^{13} \mathrm{C}$ at NSHQ14 is generally higher than $\delta^{13} \mathrm{C}$ of carbonate veins in NSHQ14 (-7.05\% VPDB to $-4.69 \%$ VPDB; (Miller et al., 2016)), which is opposite to that which would be expected at equilibrium (Bottinga, 1969), indicating that $\mathrm{CH}_{4}$ is not in isotopic equilibrium with co-existing carbonate minerals. 
Figure 3. Molecular and isotopic compositions of natural gases. (a) Plot of $\delta \mathrm{D}_{\mathrm{CH}_{4}}$ vs. $\delta^{13} \mathrm{C}_{\mathrm{CH}_{4}}$. Shaded fields of typical gas origin after Milkov and Etiope (2018). Abbreviations: PM, primary microbial; SM, secondary microbial; T, thermogenic; A, abiotic. (c) Plot of ratio of methane $\left(\mathrm{C}_{1}\right)$ to the sum of ethane $\left(\mathrm{C}_{2}\right)$ and propane $\left(\mathrm{C}_{3}\right)$ vs. $\delta^{13} \mathrm{C}_{\mathrm{CH}_{4}}$. Only analyses for which $\mathrm{C}_{2}$ was above limit of quantitation are plotted. If $\mathrm{C}_{3}$ was below limit of quantitation, its contribution to $\mathrm{C}_{1} /\left(\mathrm{C}_{2}+\mathrm{C}_{3}\right)$ was assumed to be negligible, and therefore $\mathrm{C}_{1} / \mathrm{C}_{2}$ is plotted. Fields and abbreviations same as in (a). In (a) and (c), uncertainties are smaller than plotted symbols. (b)

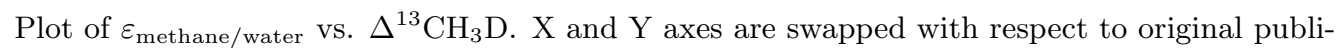
cation of this type of plot (D. T. Wang et al., 2015) so that (b) is comparable against (d). The data from (b) are plotted in the D. T. Wang et al. (2015) orientation in Supporting Information Figure S4. Equilibrium line from Horibe and Craig (1995) and E. Young et al. (2017). Abbreviations: LTA-KC, low-temperature abiotic (Kidd Creek-type); M, microbial. Green dot-dashed lines in (b) and (d) indicate a range of $\mathrm{CH}_{4}$ isotopic compositions that have been attributed to either low cell-specific rates of methanogenesis or anaerobic oxidation of methane; that is, they start at isotopic compositions produced by methanogen cultures and end at isotopic equilibrium between $5^{\circ} \mathrm{C}$ and $70^{\circ} \mathrm{C}$, which is the range of temperatures over which anaerobic oxidation of methane has been documented (D. T. Wang et al., 2015; D. Stolper et al., 2015; E. Young et al., 2017; Ash \& Egger, 2019; Giunta et al., 2019). (d) Plot of $\Delta^{13} \mathrm{CH}_{3} \mathrm{D}$ vs. $\Delta^{12} \mathrm{CH}_{2} \mathrm{D}_{2}$, after E. Young et al. (2017). Fields, abbreviations, and temperature axis same as in (b). In (b) and (d), error bars represent $95 \%$ confidence interval for analyses performed at MIT, and 1 standard error for analyses performed at UCLA. Contextual data from ophiolites: Oman/UAE (Fritz et al., 1992; Etiope et al., 2015; Boulart et al., 2013; Miller et al., 2016; Vacquand et al., 2018), the Philippines (Abrajano et al., 1990; Grozeva et al., 2020); sediment-poor seafloor hydrothermal vents: Mid-Cayman Rise (McDermott et al., 2015; D. T. Wang et al., 2018; Grozeva et al., 2020), Lost City (Proskurowski et al., 2008; D. T. Wang et al., 2018; Labidi et al., 2020), Ashadze II (J. L. Charlou et al., 2010); Precambrian Shield: Kidd Creek, Canada (Sherwood Lollar et al., 2008; E. Young et al., 2017); and laboratory Sabatier reaction catalyzed by Ru (E. Young et al., 2017).

$\mathrm{CH}_{4}$ is accompanied by $\mathrm{C}_{2}-\mathrm{C}_{6}$ alkanes in fluids from NSHQ14 (Table 4). These alkanes had $\mathrm{C}_{1} /\left(\mathrm{C}_{2}+\mathrm{C}_{3}\right)$ ratios of 1240 in 2017 and 881 in 2018, which are similar to fluid samples and rock crushings from other ophiolites and sediment-poor seafloor hydrothermal vents (Abrajano et al., 1990; J. L. Charlou et al., 2010; McDermott et al., 2015; Grozeva et al., 2020), but $10^{2}$ times higher than those of Kidd Creek mine, Canada, for which a low-temperature, abiotic origin of alkanes has been proposed (Sherwood Lollar et al., 2002, 2008; E. Young et al., 2017) (Figure 3c). Thus, $\mathrm{C}_{1} /\left(\mathrm{C}_{2}+\mathrm{C}_{3}\right)$ ratios could reflect differences in alkane formation mechanisms or extents of reaction in Precambrian shield sites like Kidd Creek versus ophiolites and sediment-poor seafloor hydrothermal vents.

$\mathrm{C}_{2} \mathrm{H}_{6}$ and $\mathrm{C}_{3} \mathrm{H}_{8}$ at NSHQ14 are strongly ${ }^{13} \mathrm{C}$-enriched $\left(\delta^{13} \mathrm{C}\right.$ of $-6.0 \%$ VPDB and $+3.3 \%$ VPDB, respectively; Table 2; Figure 4$)$. The observed $\delta^{13} \mathrm{C}$ values are $\sim 15 \%$ higher than those in the most mature (and therefore most ${ }^{13} \mathrm{C}$-enriched) thermogenic $\mathrm{C}_{2} \mathrm{H}_{6}$ and $\mathrm{C}_{3} \mathrm{H}_{8}$ samples from confined systems (Milkov \& Etiope, 2018; Fiebig et al., 2019). Increases in $\delta^{13} \mathrm{C}_{\mathrm{C}_{3}}$ of $\sim 15 \%$ have been attributed to microbial oxidation of shortchain alkanes, which enriches the residual in ${ }^{13} \mathrm{C}$ (Martini et al., 2003). However, shortchain alkane oxidizing microbial species (Shennan, 2006; Singh et al., 2017; Laso-Pérez et al., 2019) were not detected in 16S rRNA gene sequences of DNA obtained from NSHQ14. Thus, there is not strong evidence to suggest that $\delta^{13} \mathrm{C}_{\mathrm{C}_{2}}$ and $\delta^{13} \mathrm{C}_{\mathrm{C}_{3}}$ at NSHQ14 re- 
sult from post-genetic microbial alteration. Rather, $\delta^{13} \mathrm{C}_{\mathrm{C}_{2}}$ and $\delta^{13} \mathrm{C}_{\mathrm{C}_{3}}$ should reflect formation conditions and $\mathrm{C}$ source(s).

$\mathrm{C}_{2} \mathrm{H}_{6}$ and $\mathrm{C}_{3} \mathrm{H}_{8}$ at NSHQ14 are not likely to derive from nearby organic matter. Hydrocarbon-rich sedimentary formations in northern Oman not only lack a clear structural connection to the ophiolite aquifer, but also yield oils with $\delta^{13} \mathrm{C}$ values (Terken, 1999 ) at least $20 \%$ lower than those of $\mathrm{C}_{2} \mathrm{H}_{6}$ and $\mathrm{C}_{3} \mathrm{H}_{8}$ at NSHQ14. Furthermore, total organic $\mathrm{C}$ in peridotites exposed to alteration at the seafloor, a proxy for organic $\mathrm{C}$ endogenous to the Samail Ophiolite, is also relatively ${ }^{13} \mathrm{C}$-depleted (approximately $-25 \pm$ $5 \%$ VPDB; (Alt et al., 2013; Alt, Garrido, et al., 2012; Alt, Shanks, et al., 2012; Delacour et al., 2008)). Closed-system thermal cracking of these organic matter sources is unlikely to have produced the comparatively ${ }^{13} \mathrm{C}$-enriched $\mathrm{C}_{2} \mathrm{H}_{6}$ and $\mathrm{C}_{3} \mathrm{H}_{8}$ at NSHQ14 and previously reported elsewhere in the ophiolite (Figure 4; (Fritz et al., 1992)).

Thermal cracking of organic matter and open-system degassing can enrich late-produced short-chain alkanes in ${ }^{13} \mathrm{C}$ due to kinetic isotope effects associated with the cleavage of precursor sites in the parent organic matter and the resultant Rayleigh distillation of these sites (Rooney et al., 1995; Fiebig et al., 2019). Thermogenic gas production can proceed slowly at temperatures as low as $60^{\circ} \mathrm{C}$, but substantial thermogenic gas production typically occurs at reservoir temperatures above $120^{\circ} \mathrm{C}$ (Burnham, 1989; Hunt, 1996; D. A. Stolper et al., 2018; Cumming et al., 2019; Fiebig et al., 2019). These temperatures are higher than temperatures along groundwater flow paths intersecting the wells in this study. Measured groundwater temperatures in the study area are $\sim 35{ }^{\circ} \mathrm{C}$ (Table 1), and $\mathrm{H}_{2}-\mathrm{H}_{2} \mathrm{O}$ isotope thermometry and $\mathrm{C}-\mathrm{O}$ clumped isotope thermometry on carbonate veins with significant ${ }^{14} \mathrm{C}$ contents in Samail Ophiolite peridotites both indicate equilibrium $\leq 60{ }^{\circ} \mathrm{C}$ (P. B. Kelemen \& Matter, 2008; P. B. Kelemen et al., 2011; Mervine et al., 2014; Miller et al., 2016). Geothermal gradients derived from geophysical logs of NSHQ14 are $25^{\circ} \mathrm{C}$. $\mathrm{km}^{-1}$ (A. Paukert, 2014; Matter et al., 2017), which is typical of near-surface, continental settings (Lowell et al., 2014). At the low temperatures and ordinary geothermal gradients within the active alteration zone of the Samail Ophiolite, thermal cracking of organic matter is unlikely to proceed at sufficient rates to attain the high extents of reaction progress necessary to explain the observed ${ }^{13} \mathrm{C}$ enrichments in short-chain alkanes at NSHQ14 over relevant timescales.

Alternatively, short-chain alkanes in NSHQ14 fluids may have an abiotic source. Several studies have demonstrated storage of large quantities of $\mathrm{CH}_{4}$ and associated shortchain alkanes in fluid inclusions in ophiolites (Sachan et al., 2007; Klein et al., 2019; Grozeva et al., 2020). However, the findings of these studies disagree with those of Etiope et al. (2018), who measured relatively low concentrations of $\mathrm{CH}_{4}$ stored in serpentinized peridotites from Greek ophiolites. Since the rocks analyzed by Etiope et al. (2018) were sampled from outcrops, it is possible that chemical or physical processes associated with surface exposure resulted in loss of $\mathrm{CH}_{4}$ once stored in peridotite-hosted fluid inclusions prior to analysis. Although further study of the quantity and spatial distribution of $\mathrm{CH}_{4}$ storage in ophiolitic rocks is warranted, the presence of $\mathrm{CH}_{4}+\mathrm{H}_{2}$ inclusions in olivine and $\mathrm{CH}_{4} \pm$ graphite inclusions in orthopyroxene in Samail Ophiolite harzburgites (Miura et al., 2011) requires that fluid inclusions be considered as a potential source for abiotic $\mathrm{CH}_{4}$ and associated short-chain alkanes at NSHQ14 and elsewhere in the ophiolite.

A fluid inclusion source of $\mathrm{CH}_{4}$ and short-chain alkanes is compatible with $\mathrm{C}$ stable isotopic compositions of these compounds in groundwaters pumped from NSHQ14. $\mathrm{CH}_{4}, \mathrm{C}_{2} \mathrm{H}_{6}$, and $\mathrm{C}_{3} \mathrm{H}_{8} \delta^{13} \mathrm{C}$ values at NSHQ14 (-6.89\% VPDB to $+3.7 \% 0$ VPDB; Table 2) overlap with $\mathrm{CH}_{4}$ and $\mathrm{C}_{2} \mathrm{H}_{6} \delta^{13} \mathrm{C}$ values measured by Grozeva et al. (2020) in rock crushing experiments on $\mathrm{CH}_{4}$-rich fluid inclusion-bearing peridotites and dunites sampled from the Zambales ophiolite in the Philippines $(-12.4 \%$ VPDB to $-0.9 \%$ VPDB; Figure 4), which, in turn, overlap with $\delta^{13} \mathrm{C}$ values of $\mathrm{CH}_{4}$ from nearby gas seeps at Los Fuegos Eternos and Nagsasa in the Philippines $(-7.4 \%$ VPDB to $-5.6 \%$ VPDB; Figure 3a; (Abrajano et al., 1990; Vacquand et al., 2018)). Grozeva et al. (2020) also crushed 
$\mathrm{CH}_{4}$-rich fluid inclusion-bearing rocks from the Mid-Cayman Rise. Of the Mid-Cayman Rise samples that yielded sufficient $\mathrm{CH}_{4}$ and $\mathrm{C}_{2} \mathrm{H}_{6}$ for precise $\mathrm{C}$ isotopic analysis, which were all mafic intrusive rocks, $\delta^{13} \mathrm{C}$ values ranged from $-14.0 \%$ VPDB to $+0.7 \%$ VPDB. The lower end of Mid-Cayman Rise rock crushing short-chain alkane $\delta^{13} \mathrm{C}$ values are similar to those measured in Mid-Cayman Rise hydrothermal vent fluids $(-15.8 \%$ VPDB to $-9.7 \%$ VPDB; (McDermott et al., 2015)), whereas the higher end are similar to those of NSHQ14 (Figure 4). Furthermore, $\mathrm{C}_{2} \mathrm{H}_{6}$ and $\mathrm{C}_{3} \mathrm{H}_{8} \delta^{13} \mathrm{C}$ values of NSHQ14 fluids resemble those of fluids discharging from the sediment-poor hydrothermal vents at Ashadze II, Mid-Atlantic Ridge (Figure 4; (J. L. Charlou et al., 2010)). The similarities in shortchain alkane $\delta^{13} \mathrm{C}$ values between circulating fluids and rock-hosted fluid inclusions in ophiolites and present-day oceanic lithospheric sites suggest that circulating fluids in both environments derive much of their $\mathrm{CH}_{4}$ and short-chain alkanes from fluid inclusions.

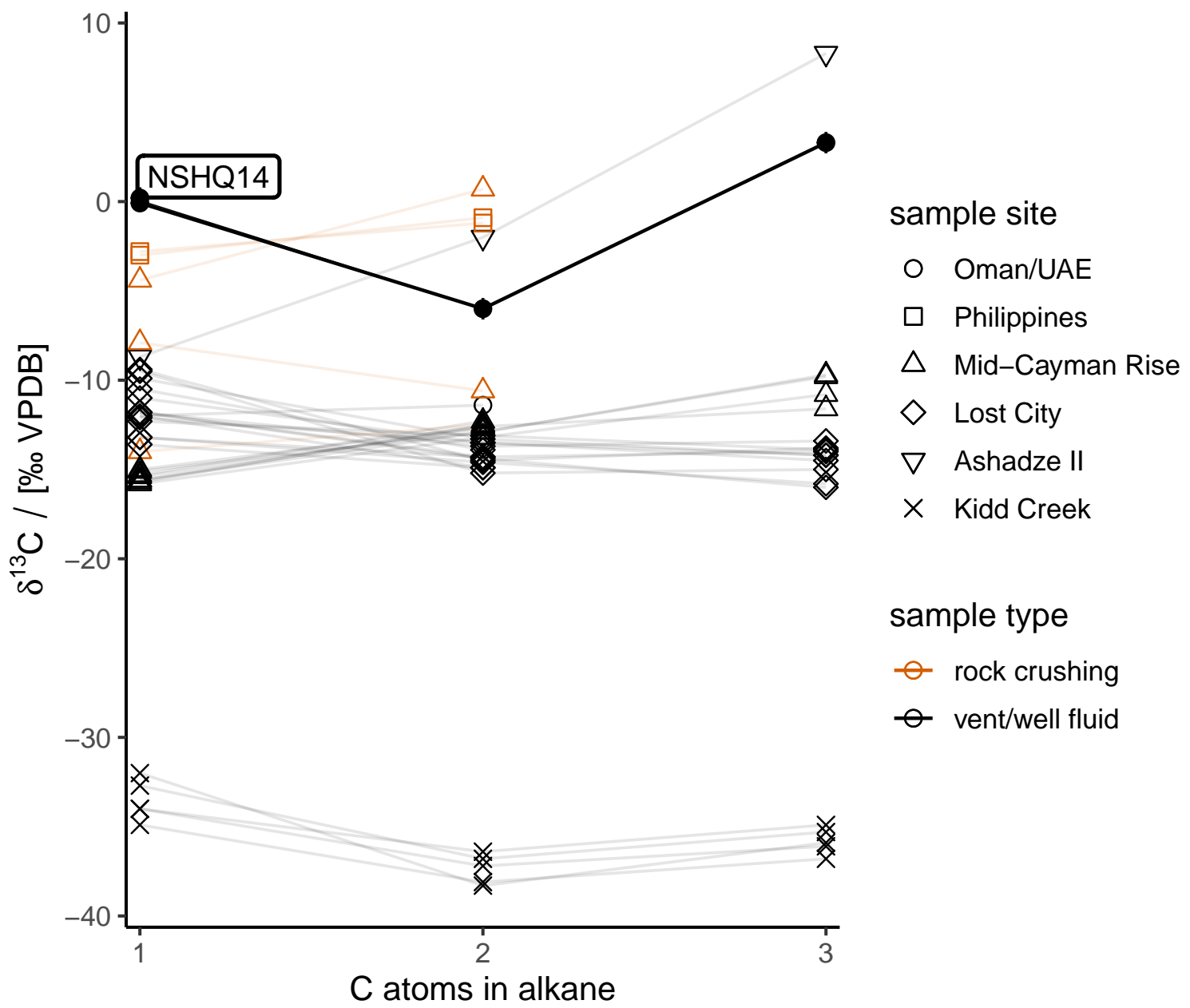

Figure 4. Plot of $\delta^{13} \mathrm{C}$ of $\mathrm{CH}_{4}$ and co-occurring $n$-alkanes vs. the number of $\mathrm{C}$ atoms per molecule. Error bars represent uncertainties on $\delta^{13} \mathrm{C}$ analyses performed at CUB. Only samples for which $\delta^{13} \mathrm{C}_{\mathrm{C}_{2}}$ was determined are plotted. Contextual data from ophiolites: Oman/UAE (Fritz et al., 1992), the Philippines (Grozeva et al., 2020); sediment-poor seafloor hydrothermal vents: Mid-Cayman Rise (McDermott et al., 2015; Grozeva et al., 2020), Lost City (Proskurowski et al., 2008), Ashadze II (J. L. Charlou et al., 2010); and Precambrian Shield: Kidd Creek, Canada (Sherwood Lollar et al., 2008). 
Sources of $\mathrm{CH}_{4}$ can also be assessed by measuring $\mathrm{H}$ isotopic compositions and clumped isotopologue relative abundances of $\mathrm{CH}_{4}$ and comparing these isotopic compositions to temperature-dependent equilibria. These isotopic equilibria are represented by thick gray lines in Figure 3b and d. Intra- $\mathrm{CH}_{4}$ equilibrium is governed by the increasing relative stability of bonds between two heavy isotopes (more "clumping") at lower temperatures, which is reflected in higher $\Delta^{13} \mathrm{CH}_{3} \mathrm{D}$ and $\Delta^{12} \mathrm{CH}_{2} \mathrm{D}_{2}$ values. However, isotopic equilibrium will only be expressed if kinetics allow it. In the first study to publish clumped isotopologue $\left(\Delta^{13} \mathrm{CH}_{3} \mathrm{D}\right)$ data on $\mathrm{CH}_{4}$ - and $\mathrm{H}_{2}$ - rich gases from sediment-poor seafloor hydrothermal vents, D. T. Wang et al. (2018) found that these gases yielded apparent $\mathrm{CH}_{4}-\mathrm{H}_{2} \mathrm{O} \mathrm{H}$ isotopic and $\Delta^{13} \mathrm{CH}_{3} \mathrm{D}$ equilibrium temperatures of $270{ }^{\circ} \mathrm{C}$ to $360^{\circ} \mathrm{C}$, despite having a range of effluent fluid temperatures from $96{ }^{\circ} \mathrm{C}$ to $370^{\circ} \mathrm{C}$. This was interpreted as evidence for a closure temperature of $270^{\circ} \mathrm{C}$ for $\mathrm{H}$ isotope exchange in the $\mathrm{CH}_{4}-\mathrm{H}_{2} \mathrm{O}$ and $\mathrm{CH}_{4}-\mathrm{H}_{2}$ systems in seafloor hydrothermal settings (e.g. Mid-Cayman Rise in Figure $3 \mathrm{~b}$ and $\mathrm{d}$ ). However, in a subsequent study that re-analyzed some of the same samples, plus a greater number of samples from low-temperature vents at Lost City $\left(96{ }^{\circ} \mathrm{C}\right.$ to $\left.64^{\circ} \mathrm{C}\right)$, and contributed the first $\Delta^{12} \mathrm{CH}_{2} \mathrm{D}_{2}$ values from these settings, Labidi et al. (2020) found evidence for re-equilibration of clumped isotopologue and $\mathrm{CH}_{4}-\mathrm{H}_{2} \mathrm{O}$ $\mathrm{H}$ isotopic systems at lower temperatures. Of these isotopic systems, that of ${ }^{12} \mathrm{CH}_{2} \mathrm{D}_{2}$ had the fastest apparent re-equilibration kinetics (approximately twice as fast as ${ }^{13} \mathrm{CH}_{3} \mathrm{D}$ ), which was explained by differences in symmetry numbers among the isotopologues. The ${ }^{12} \mathrm{CH}_{2} \mathrm{D}_{2}$-based temperatures of the Lost City samples, which were as low as $69_{-4}^{+4}{ }^{\circ} \mathrm{C}$, closely matched their end member vent fluid temperatures. As a result of the apparent faster re-equilibration of ${ }^{12} \mathrm{CH}_{2} \mathrm{D}_{2}$, the Lost City data plot above the ${ }^{13} \mathrm{CH}_{3} \mathrm{D}-{ }^{12} \mathrm{CH}_{2} \mathrm{D}_{2}$ equilibrium line (towards higher $\Delta^{12} \mathrm{CH}_{2} \mathrm{D}_{2}$ ) in Figure $3 \mathrm{~d}$. Therefore, isotopic compositions of $\mathrm{CH}_{4}$ formed in fluid inclusions in the oceanic lithosphere and stored for millions of years at low temperatures may be expected to fall somewhere along a continuum from $\Delta^{13} \mathrm{CH}_{3} \mathrm{D}, \Delta^{12} \mathrm{CH}_{2} \mathrm{D}_{2}$, and $\mathrm{CH}_{4}-\mathrm{H}_{2} \mathrm{O}$ isotopic equilibrium at $\sim 330^{\circ} \mathrm{C}$ to compositions approaching lower temperature $\left(\sim 70^{\circ} \mathrm{C}\right.$ or perhaps even lower $)$ equilibrium, with ${ }^{12} \mathrm{CH}_{3} \mathrm{D},{ }^{13} \mathrm{CH}_{3} \mathrm{D}, \mathrm{CH}_{4}-\mathrm{H}_{2} \mathrm{O}$ isotopic re-equilibration proceeding at varying rates. This is not the case for Samail Ophiolite samples, as detailed below.

Across five years of samples from NSHQ14, $\delta \mathrm{D}_{\mathrm{CH}_{4}}$ has ranged from $-232 \%$ VSMOW to $-311.73 \%$ VSMOW, with a mean weighted by sample year of $-275 \%$ VSMOW (Figure 3a; Table 2). This $\mathrm{CH}_{4}$ is D-enriched with respect to coexisting $\mathrm{H}_{2}\left(\delta \mathrm{D}_{\mathrm{H}_{2}}=-685 \%\right.$ VSMOW; (Miller et al., 2016)) and D-depleted with respect to coexisting water $\left(\delta \mathrm{D}_{\mathrm{H}_{2} \mathrm{O}}=+0.2 \%\right.$ VSMOW in 2018; Table 3). Although $\mathrm{H}_{2}$ and water reflect $\mathrm{H}$ isotopic equilibrium at $\sim 50{ }^{\circ} \mathrm{C}$ (Miller et al., 2016), both $\mathrm{H}_{2}$ and water are in $\mathrm{H}$ isotopic disequilibrium with $\mathrm{CH}_{4}$ (Figure $3 \mathrm{~b}$ ). Moreover, NSHQ14 fluids exhibit intra- $\mathrm{CH}_{4}$ disequilibrium, as indicated by ${ }^{13} \mathrm{CH}_{3} \mathrm{D}$ and $\Delta^{12} \mathrm{CH}_{2} \mathrm{D}_{2}$ values (Table 2) plotting below the equilibrium line in Figure $3 \mathrm{~d}$. These non-equilibrium isotopic compositions indicate that post-genetic alteration of $\mathrm{CH}_{4}$ must have occurred or that fluid inclusions are not the only source of $\mathrm{CH}_{4}$ at $\mathrm{NSHQ} 14$.

One potential post-genetic alteration mechanism is diffusion. However, $\mathrm{CH}_{4}$ at $\mathrm{NSHQ} 14$ cannot be the diffusion residual of $\mathrm{CH}_{4}$ that was originally at intramolecular equilibrium (or with $\Delta^{12} \mathrm{CH}_{2} \mathrm{D}_{2}$ above the apparent $\Delta^{13} \mathrm{CH}_{3} \mathrm{D}$ equilibrium temperature) because the diffusion slope (change in $\Delta^{12} \mathrm{CH}_{2} \mathrm{D}_{2}$ over change in $\Delta^{13} \mathrm{CH}_{3} \mathrm{D}$ ) is shallower than the equilibrium line slope over the relevant temperature range (E. Young et al., 2017). Another potential alteration mechanism is microbial $\mathrm{CH}_{4}$ oxidation. Two types of microbial $\mathrm{CH}_{4}$ oxidation have been studied for their effects on $\mathrm{CH}_{4}$ clumped isotopologue relative abundances: anaerobic methane oxidation of the ANME type and aerobic $\mathrm{CH}_{4}$ oxidation. ANMEtype anaerobic methane oxidation is suggested to be a highly reversible metabolic pathway (Knittel \& Boetius, 2009; Timmers et al., 2017). This reversibility has been proposed to bring $\Delta^{13} \mathrm{CH}_{3} \mathrm{D}$ and $\Delta^{12} \mathrm{CH}_{2} \mathrm{D}_{2}$ towards equilibrium at low temperatures $\left(70^{\circ} \mathrm{C}\right.$ to $30^{\circ} \mathrm{C}$ ) through continuous breaking and reforming of bonds in the $\mathrm{CH}_{4}$ molecule (E. Young et al., 2017; Ash \& Egger, 2019; Giunta et al., 2019). Thus, the comparatively low $\Delta^{13} \mathrm{CH}_{3} \mathrm{D}$ and $\Delta^{12} \mathrm{CH}_{2} \mathrm{D}_{2}$ values observed in samples from NSHQ14 and other wells in this study 
(Figure 3b and d) do not support a major role for anaerobic methane oxidation in the study area. Aerobic $\mathrm{CH}_{4}$ oxidation is less reversible than ANME-type anaerobic methane oxidation due to differences in the enzymes and electron acceptors used for those respective processes. For this reason, aerobic $\mathrm{CH}_{4}$ oxidation does not bring $\mathrm{CH}_{4}$ into isotopic equilibrium, but rather imparts a normal, classical kinetic isotope effect during $\mathrm{CH}_{4}$ consumption. In a study of the effect of aerobic $\mathrm{CH}_{4}$ oxidation on $\Delta^{13} \mathrm{CH}_{3} \mathrm{D}$, D. T. Wang et al. (2016) found that the fractionation factor for ${ }^{13} \mathrm{CH}_{3} \mathrm{D}$ was closely approximated by the product of the fractionation factors for ${ }^{13} \mathrm{CH}_{4}$ and ${ }^{12} \mathrm{CH}_{3} \mathrm{D}$. Although it has not yet been demonstrated experimentally, it is hypothesized that the fractionation factor for ${ }^{12} \mathrm{CH}_{2} \mathrm{D}_{2}$ during aerobic $\mathrm{CH}_{4}$ oxidation may likewise be approximated by the square of the fractionation factor for ${ }^{12} \mathrm{CH}_{3} \mathrm{D}$ (E. D. Young, 2020). This "product rule" for isotopic fractionation during aerobic $\mathrm{CH}_{4}$ oxidation results in decreases in $\Delta^{13} \mathrm{CH}_{3} \mathrm{D}$ and $\Delta^{12} \mathrm{CH}_{2} \mathrm{D}_{2}$ with concomitant increases in $\delta^{13} \mathrm{C}$ and $\delta \mathrm{D}$ in residual $\mathrm{CH}_{4}$ (D. T. Wang et al., 2016; E. D. Young, 2020). Thus, aerobic $\mathrm{CH}_{4}$ oxidation could draw $\Delta^{13} \mathrm{CH}_{3} \mathrm{D}$ and $\Delta^{12} \mathrm{CH}_{2} \mathrm{D}_{2}$ values originally near equilibrium down below the equilibrium line in Figure 3d. However, if $\mathrm{CH}_{4}$ samples from NSHQ14 were originally near $\mathrm{H}$ isotope equilibrium with water of SMOW-like isotopic composition, aerobic methane oxidation would push the residual $\mathrm{CH}_{4}$ towards higher $\delta \mathrm{D}$ (and $\varepsilon_{\text {methane/water) }}$ ) values (above the equilibrium line in Figure 3b), which is inconsistent with the comparatively low $\delta \mathrm{D}_{\mathrm{CH}_{4}}$ observed at NSHQ14.

For the reasons outlined above, post-genetic alteration of $\mathrm{CH}_{4}$ near $\mathrm{CH}_{4}-\mathrm{H}_{2} \mathrm{O}$ and intramolecular isotopic equilibrium does not explain the observed isotopic compositions of $\mathrm{CH}_{4}$ sampled from NSHQ14. Therefore, the release of $\mathrm{CH}_{4}$ stored in fluid inclusions cannot account for all of the $\mathrm{CH}_{4}$ at NSHQ14. Alternative processes that do produce $\mathrm{CH}_{4}$ with $\Delta^{13} \mathrm{CH}_{3} \mathrm{D}$ and $\Delta^{12} \mathrm{CH}_{2} \mathrm{D}_{2}$ values lower than equilibrium include microbial methanogenesis and low-temperature $\left(\leq 90^{\circ} \mathrm{C}\right)$ abiotic reduction of $\mathrm{CO}_{2}$ or $\mathrm{CO}$ through Sabatier or Fischer-Tropsch-type reactions. In Figure 3b and d, microbial methanogenesis is represented by samples from cultures (green shaded areas; (D. T. Wang et al., 2015; D. Stolper et al., 2015; E. Young et al., 2017; Gruen et al., 2018; E. D. Young, 2020)), and low-temperature Sabatier or Fischer-Tropsch-type reactions are represented by field samples from Kidd Creek (gray shaded areas; (E. Young et al., 2017; Sherwood Lollar et al., 2002, 2008)) and laboratory experiments with synthetic Ru catalysts (E. Young et al., 2017; Etiope \& Ionescu, 2015).

To independently assess the potential influences of microbial processes on $\mathrm{CH}_{4}$ concentration and isotopic composition, DNA was extracted from biomass in pumped groundwaters and subjected to amplification and sequencing of $16 \mathrm{~S}$ rRNA genes. 16S rRNA gene sequences of biomass collected in 2018 were searched for matches to known $\mathrm{CH}_{4}$-cycling taxa, as compiled previously by Crespo-Medina et al. (2017). Sequences closely affiliated with both methanogenic and methanotrophic taxa were found to be widespread in the aquifer (Figure 5). Based on phylogenetic inference, the dominant methanogenic taxon was related to the genus Methanobacterium, whose members can produce $\mathrm{CH}_{4}$ from $\mathrm{H}_{2}$ and $\mathrm{CO}_{2}$, CO, or formate (Balch et al., 1979). Methanobacterium comprised a high proportion $(24 \%)$ of $16 \mathrm{~S}$ rRNA gene sequences at NSHQ14 in 2018. Relative abundances of Methanobacterium 16S rRNA gene reads were similarly high in 2017 (12\%) and 2016 (28\%), but lower $(<1 \%)$ in 2015 and 2014 (Miller et al., 2016; Rempfert et al., 2017; Kraus et al., 2021). The increase in the relative abundance of $16 \mathrm{~S}$ rRNA genes affiliated with Methanobacterium in samples collected in 2016 and onwards versus those collected in 2014 and 2015 coincided with a change in sampling methods from smaller, lower-flow pumps (maximum depth $20 \mathrm{~m}$ ) prior to 2016 to larger, higher-flow pumps (maximum depth $90 \mathrm{~m}$ ). The obligate anaerobic nature of this methanogen genus (Boone, 2015) is consistent with its higher relative gene abundances in fluids sampled from greater depths, which presumably receive less input of atmospheric $\mathrm{O}_{2}$ than do shallower fluids. 


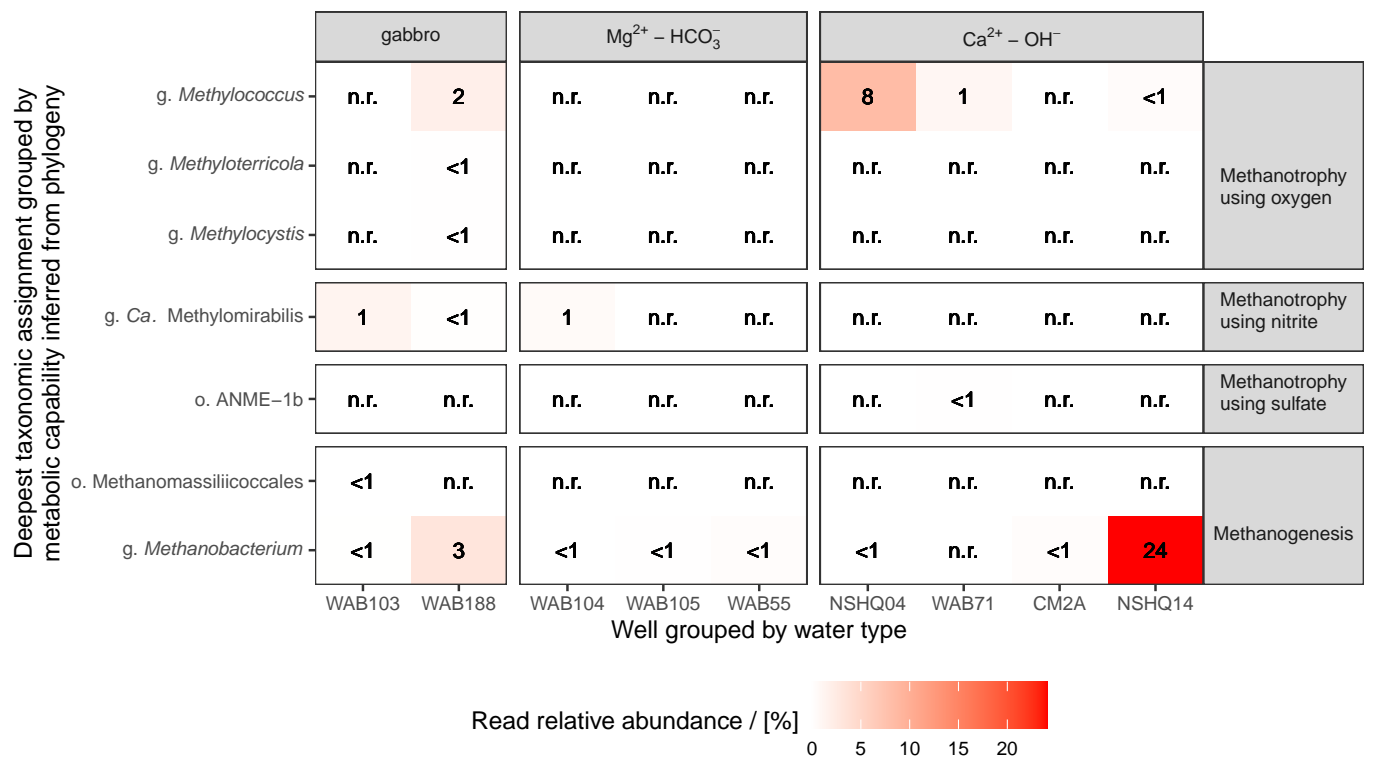

Figure 5. 16S rRNA gene read relative abundances of DNA extracted from Samail Ophiolite groundwaters sampled in 2018 affiliated with $\mathrm{CH}_{4}$-cycling taxa. Read relative abundances are reported as percentages rounded to the ones place. Cases when a taxon was detected in a sample and was $<1 \%$ read relative abundance after rounding are labeled " $<1$ ". Cases when no reads of a taxon were detected in a sample are labeled "n.r." Data shown are from unique field samples. Previous 16S rRNA gene sequencing studies that obtained field samples in triplicate from Samail Ophiolite groundwaters through similar methods to those used here have found typical standard deviations of relative abundances less than or equal to $25 \%$ of the mean relative abundance (Kraus et al., 2021).

Consortia capable of anaerobic oxidation of $\mathrm{CH}_{4}$ coupled to $\mathrm{SO}_{4}^{2-}$ reduction, including ANME, were not detected by $16 \mathrm{~S}$ rRNA gene sequencing of samples obtained from NSHQ14 in 2018 (Figure 5), 2016, or 2014 (Miller et al., 2016; Rempfert et al., 2017), although sequences affiliated with order ANME-1b were detected in low abundance $(<$ $1 \%$ of reads) in samples obtained from NSHQ14 in 2017 and 2015 (Rempfert et al., 2017; Kraus et al., 2021). This scarcity of ANME may result from metabolic inhibition by high $c_{\mathrm{H}_{2}}$ in groundwaters at NSHQ14 and elsewhere in the Samail Ophiolite. It has been proposed that the thermodynamics of "reverse methanogenesis" require low $c_{\mathrm{H}_{2}}$ (e.g. $\leq 1 \mathrm{nM}$ in a marine cold seep environment (Boetius et al., 2000)). Indeed, the bioenergetics of $\mathrm{SO}_{4}^{2-}$-driven oxidation of $\mathrm{CH}_{4}$ are less favorable than $\mathrm{SO}_{4}^{2-}$-driven oxidation of $\mathrm{H}_{2}$ or non- $\mathrm{CH}_{4}$ organics, or other metabolisms such as methanogenesis or acetogenesis in the Samail Ophiolite (Canovas III et al., 2017) and in deep continental settings where radiolytic $\mathrm{H}_{2}$ accumulates (Kieft et al., 2005; Moser et al., 2005; Kieft, 2016).

While $16 \mathrm{~S}$ rRNA gene sequences affiliated with anaerobic $\mathrm{CH}_{4}$ oxidizing microbes have only occasionally been detected at NSHQ14, 16S rRNA gene sequences affiliated with the genus Methylococcus, which contains aerobic methanotrophs (Hanson \& Hanson, 1996), have been detected in all samples from NSHQ14, ranging from $1 \%$ to $<1 \%$ of reads in samples obtained from 2014 to 2018 (Figure 5; (Miller et al., 2016; Rempfert et al., 2017; Kraus et al., 2021)). Since the aerobic lifestyle of Methylococcus is at odds with that of the obligate anaerobe, Methanobacterium, it seems most likely that these two taxa are spatially separated in the aquifer, and that waters containing each of them 
were mixed during open borehole pumping. Still, the $>10$ times higher abundances of Methanobacterium-related 16S rRNA genes relative to those of Methylococcus at NSHQ14 in samples from 2016 to 2018 suggest that the microbial $\mathrm{CH}_{4}$ cycle at this well is dominated by $\mathrm{CH}_{4}$ production, rather than consumption.

16S rRNA gene sequencing of subsurface biomass from NSHQ14 is complemented by other observations that suggest that methanogens are not only prevalent, but active. Genes involved in methanogenesis are enriched (Fones et al., 2019) and actively transcribed in waters sampled from NSHQ14 (Kraus et al., 2021). Transformation of both ${ }^{14} \mathrm{C}$-labeled $\mathrm{HCO}_{3}^{-}$and ${ }^{14} \mathrm{C}$-labeled formate to $\mathrm{CH}_{4}$ have been shown to occur in water samples from NSHQ14 at significantly higher rates than in killed controls, with formatotrophic methanogenesis greatly outpacing hydrogenotrophic methanogenesis (Fones et al., 2019, 2020). Taken together with a cell abundance of $1.15 \cdot 10^{5}$ cells $\cdot \mathrm{mL}^{-1}$ in groundwater at NSHQ14 (Fones et al., 2019), these data suggest that aquifer regions accessed by NSHQ14 host abundant active methanogenic cells (thousands per mL, assuming $\sim 24 \%$ of cells are methanogens based on $16 \mathrm{~S}$ rRNA gene data). These active cells could influence $\mathrm{CH}_{4}$ concentration and isotopic composition.

The genomic and cultivation data of Fones et al. (2020) indicate that formate is the dominant substrate for methanogenesis at NSHQ14. Formate concentrations are $1 \mu \mathrm{mol}$. $\mathrm{L}^{-1}$ to $2 \mu \mathrm{mol} \cdot \mathrm{L}^{-1}$ in the studied wells (Rempfert et al., 2017), which are roughly two orders of magnitude lower than formate concentrations at unsedimented seafloor hydrothermal vents impacted by serpentinization at warmer conditions than present in the Samail Ophiolite (McDermott et al., 2015; Lang et al., 2018). These relatively low formate concentrations in the ophiolite suggest that formate might be the primary limiting substrates for methanogenesis in $\mathrm{Ca}^{2+}-\mathrm{OH}^{-}$waters, such as at NSHQ14. Coexisting hydrogenotrophic methanogens may produce $\mathrm{CH}_{4}$ through direct uptake of $\sum \mathrm{CO}_{2}$ in $\mathrm{H}_{2}$-rich $\mathrm{Ca}^{2+}-\mathrm{OH}^{-}$ water, where kinetic inhibitions to abiotic $\sum \mathrm{CO}_{2}$ reduction to $\mathrm{CH}_{4}$ allow for a modest energy yield for hydrogenotrophic methanogens (Section 5; (Leong \& Shock, 2020)). Methanogens using $\sum \mathrm{CO}_{2}$ could benefit from greater chemical disequilibrium if they inhabit zones where deeply-sourced, $\mathrm{H}_{2}$-rich $\mathrm{Ca}^{2+}-\mathrm{OH}^{-}$water mixes with shallow, $\mathrm{Mg}^{2+}-\mathrm{HCO}_{3}^{-}$ water (Zwicker et al., 2018; Leong \& Shock, 2020). In addition to direct uptake of $\sum \mathrm{CO}_{2}$, carbonate minerals may serve as a $\mathrm{C}$ source for methanogenesis in carbonated peridotites (Miller et al., 2018). Another potential C source is carbon monoxide (CO). CO has always been below limits of quantitation in Oman wells $\left(<132 \mathrm{nmol} \cdot \mathrm{L}^{-1}\right.$ in 2018 ; Table 4), but it is unclear whether this indicates minimal CO production or rapid CO turnover.

The microbiological data from NSHQ14 fluids are compatible with $\delta \mathrm{D}_{\mathrm{CH}_{4}}, \Delta^{13} \mathrm{CH}_{3} \mathrm{D}$, and $\Delta^{12} \mathrm{CH}_{2} \mathrm{D}_{2}$ values that collectively indicate a substantial addition of microbial $\mathrm{CH}_{4}$ to an otherwise abiotic pool of $\mathrm{CH}_{4}$. Although the data presented here do not enable us to precisely determine the mole fractions and isotopic compositions of the microbial and abiotic components of $\mathrm{CH}_{4}$ at NSHQ14, the $\delta \mathrm{D}_{\mathrm{CH}_{4}}$ data alone suggest that perhaps the majority of $\mathrm{CH}_{4}$ at NSHQ14 formed through non-equilibrium processes, which include microbial methanogenesis. Thus, the high $\delta^{13} \mathrm{C}$ of $\mathrm{CH}_{4}$ at NSHQ14 suggests that the microbial component is more ${ }^{13} \mathrm{C}$-enriched than microbial $\mathrm{CH}_{4}$ formed in sedimentary environments, which typically ranges from $-90 \%$ VPDB to $-50 \%$ VPDB ((Milkov \& Etiope, 2018); Figure 3a). In cultures of a hydrogenotorophic strain of Methanobacterium provided $\mathrm{CaCO}_{3}(s)$ as a $\mathrm{C}$ source at $\mathrm{pH} \sim 9$, Miller et al. (2018) observed suppressed apparent isotope effects during methanogenesis $\left(\alpha_{\mathrm{CO}_{2} / \mathrm{CH}_{4}}=1.028\right)$. The authors attributed this to the slow kinetics of carbonate dissolution at high $\mathrm{pH}$ and the neartotal conversion of the resultant $\mathrm{CO}_{2}$ (aq) to $\mathrm{CH}_{4}$ by Methanobacterium. If the primary mode of methanogenesis at NSHQ14 is in fact formatotrophic methanogenesis and abiotic formate production is the rate-limiting step in the overall process through which $\sum \mathrm{CO}_{2}$ is converted to $\mathrm{CH}_{4}$, similar isotopic bottlenecks could apply. Cellular formate uptake and enzymatic conversion processes whose isotope effects remain unknown could be important drivers of the isotopic composition of $\mathrm{CH}_{4}$ in hyperalkaline, serpentinizing set- 
tings. In such settings, the suppression of $\mathrm{C}$ isotope fractionation during methanogenesis is supported by observations of high $\delta^{13} \mathrm{C}$ values (up to $+14 \%$ VPDB) of lipid biomarkers thought to be produced by methanogens at Chimaera, Turkey (Zwicker et al., 2018) and at Lost City (Bradley et al., 2009). Evaluation of these hypotheses will require further physiological studies of methanogens aimed at understanding substrate selection and limitation systematics in hyperalkaline, low- $\mathrm{C}$ conditions and the isotopic implications of these factors.

While the data support substantial microbial $\mathrm{CH}_{4}$ and abiotic, fluid inclusion-derived $\mathrm{CH}_{4}$ in NSHQ14 fluids, we find less evidence for abiotic $\mathrm{CH}_{4}$ production at the low temperatures that pervade the modern weathering horizon in the ophiolite. Below $100^{\circ} \mathrm{C}$, access of gas-phase $\mathrm{H}_{2}$ and $\mathrm{CO}_{2}$ or $\mathrm{CO}$ to the catalytic metals $\mathrm{Ru}$ or $\mathrm{Rh}$ is required for $\mathrm{CH}_{4}$ to form at appreciable rates (Thampi et al., 1987; Jacquemin et al., 2010; Etiope \& Ionescu, 2015; McCollom, 2016). It has been proposed that the spatial concentration of potentially-catalytic Ru-rich chromites in chromitites is important for catalysis of lowtemperature $\mathrm{CO}_{2}$ reduction to $\mathrm{CH}_{4}$ in ophiolites (Etiope \& Ionescu, 2015; Etiope et al., 2018). While peridotites in Oman ubiquitously contain a few percent distributed chromite (Hanghøj et al., 2010), massive chromitites were not reported in lithologic descriptions of cores or drill cuttings from NSHQ14 or any of the six additional wells ranging from $300 \mathrm{~m}$ to $400 \mathrm{~m}$ depth that have been drilled in the same catchment by the Oman Drilling Project (P. Kelemen et al., 2020). Nor are chromitites notably abundant in outcrop within this catchment. Further, although some flow paths of meteoric water through the ophiolite may result in saturation in $\mathrm{H}_{2}$ and separation of a free gas phase (Canovas III et al., 2017), the depth to water is $<20 \mathrm{~m}$ in all wells in the catchment of NSHQ14, suggesting water-saturated conditions in the subsurface. Moreover, if free $\mathrm{H}_{2}(\mathrm{~g})$ were generated at high extents of reaction progress, co-existing $\mathrm{CO}_{2}(\mathrm{~g})$ would be extremely scarce due to precipitation of carbonate minerals and high $\mathrm{pH}$ (Etiope \& Ionescu, 2015; Leong \& Shock, 2020). It has been proposed that $\mathrm{CH}_{4}$ in ophiolites can form through reduction of $\mathrm{CO}_{2}(\mathrm{~g})$ from non-atmospheric sources such as magma, the mantle, or sedimentary carbonate formations (Etiope \& Ionescu, 2015). A magmatic/mantle $\mathrm{CO}_{2}$ source is not supported at NSHQ14 because excess He above air saturation in groundwaters from this well has a dominantly radiogenic isotopic composition that is distinct from mantlederived He (Paukert Vankeuren et al., 2019). Further, although sedimentary carbonates are present in the vicinity of NSHQ14 and elsewhere in the ophiolite (Boudier \& Coleman, 1981; de Obeso \& Kelemen, 2018), there is no clear mechanism to liberate $\mathrm{CO}_{2}(\mathrm{~g})$ from mineral carbonates and transfer that $\mathrm{CO}_{2}(\mathrm{~g})$ to catalytic sites of reaction on chromites where $\mathrm{H}_{2}(\mathrm{~g})$ is also present. Thus, the apparent lack of massive chromites and free gaseous potential reactants suggest that the subsurface surrounding NSHQ14 is not conducive to low-temperature abiotic $\mathrm{CH}_{4}$ production. While substantial low-temperature $\mathrm{CH}_{4}$ production in the catchment of NSHQ14 seems unlikely, NSHQ14 groundwaters could be mere carriers of $\mathrm{CH}_{4}$ that was produced elsewhere in the ophiolite under gaseous conditions and that has subsequently migrated into the aquifer. Some studies of $\mathrm{CH}_{4}$ origin in other peridotite bodies have favored such a hypothesis (Etiope et al., 2016; Marques et al., 2018). However, it is not clear how this hypothesis could be tested in the case of the NSHQ14, nor how it addresses the issue of $\mathrm{CO}_{2}$ source.

In summary, isotopic and microbiological data lead us to conclude that the high concentrations of $\mathrm{CH}_{4}\left(10^{2} \mu \mathrm{mol} \cdot \mathrm{L}^{-1}\right)$ in groundwaters accessed by NSHQ14 primarily result from microbial methanogenesis and the release of abiotic $\mathrm{CH}_{4}$ from fluid inclusions. The known presence of $\mathrm{CH}_{4}$-bearing fluid inclusions in the Samail Ophiolite and our finding of high $\delta^{13} \mathrm{C}$ values of $\mathrm{CH}_{4}, \mathrm{C}_{2} \mathrm{H}_{6}$, and $\mathrm{C}_{3} \mathrm{H}_{8}$ that overlap with values reported from seafloor hydrothermal vents where $\mathrm{CH}_{4}$ formed at $>270{ }^{\circ} \mathrm{C}$ in fluid inclusions predominates suggest a similar source in the ophiolite. However, deficits in ${ }^{12} \mathrm{CH}_{3} \mathrm{D},{ }^{13} \mathrm{CH}_{3} \mathrm{D}$, and ${ }^{12} \mathrm{CH}_{2} \mathrm{D}_{2}$ relative to equilibrium indicate the production of additional $\mathrm{CH}_{4}$ at low temperatures. The ${ }^{13} \mathrm{CH}_{3} \mathrm{D}$ deficit in particular is more compatible with a microbial origin than a low-temperature abiotic origin. Moreover, genomic, transcriptomic, and phys- 
iological data show that methanogens are abundant and active in aquifers accessed via NSHQ14. Organic geochemical and cultivation data from the literature suggest that C isotope effects of methanogenesis may be suppressed under C-limited conditions in serpentinizing settings. That genes associated with methanogens coexist with a smaller abundance of genes associated with methanotrophs (particularly aerobes) in NSHQ14 groundwaters suggests that some of the $\mathrm{CH}_{4}$ has undergone microbial oxidation, which would further help explain the high $\delta^{13} \mathrm{C}$ values of $\mathrm{CH}_{4}$ at this well.

\subsubsection{Abundant microbial $\mathrm{CH}_{4}$ produced under $\mathrm{C}$-limited conditions and substantial microbial $\mathrm{CH}_{4}$ oxidation in the $\mathrm{Ca}^{2+}-\mathrm{OH}^{-}$waters of well NSHQO4}

NSHQ04 is situated in partially serpentinized harzburgite $10 \mathrm{~m}$ away from a faulted contact with crustal gabbros (Figure 1; Supporting Information Figure S1). Surface rock exposures surrounding NSHQ04 are dominated by serpentinized harzburgites, with lesser dunites, gabbro lenses, and pyroxenite dikes. NSHQ04 is cased to $5.8 \mathrm{mbgl}$ and drilled to $304 \mathrm{~m}$ depth (Table 1). As of 2017, the well is obstructed at $8 \mathrm{~m}$ below the casing top, precluding deeper sampling (Section 3.1; Table 1).

Primary differences in fluid composition between NSHQ04 and NSHQ14 include lower $\mathrm{pH}$ by $\sim 1$ and higher $c_{\sum_{\mathrm{Ca}}}$ and $c_{\sum \mathrm{Si}}$ at NSHQ04 (Tables 1 and 3; (Miller et al., 2016; Rempfert et al., 2017; Paukert Vankeuren et al., 2019; Fones et al., 2019)). These differences could be related to the scarcity of fresh, near-surface olivine at NSHQ04, which may result in a greater influence of pyroxene serpentinization at NSHQ04 (Miller et al., 2016). Low-temperature pyroxene serpentinization generally continues after olivine is exhausted, and leads to higher $c \sum_{\mathrm{Si}}$ and, depending on pyroxene chemical composition, can also lead to higher $c_{\sum_{\mathrm{Ca}}}$ and lower $\mathrm{pH}$ (Bach et al., 2006; Leong \& Shock, 2020). The relatively low $\mathrm{pH}$ and high $c_{-\mathrm{Si}}$ could also stem from mixing of $\mathrm{Ca}^{2+}-\mathrm{OH}^{-}$waters with gabbro- or atmosphere-influenced fluids.

Compared to NSHQ14, NSHQ04 has generally had lower $c_{\mathrm{H}_{2}}$ (detected in 2014, but not in 2018, 2017, 2015, or 2012; Table 4; Figure 2; (Miller et al., 2016; Rempfert et al., 2017; Paukert Vankeuren et al., 2019)). The relatively low $c_{\mathrm{H}_{2}}$ measured in waters pumped from NSHQ04 is probably due at least in part to microbial $\mathrm{H}_{2}$ oxidation. Although there are multiple enzymes with which which a diversity of microbes oxidize $\mathrm{H}_{2}$ (Peters et al., 2015), aerobic $\mathrm{H}_{2}$ oxidation by bacteria of the genus Hydrogenophaga has been identified as a particularly prevalent process in serpentinizing settings, including the Samail Ophiolite (Suzuki et al., 2014; Rempfert et al., 2017; Marques et al., 2018). Sequences affiliated with Hydrogenophaga accounted for $20 \%$ of $16 \mathrm{~S}$ rRNA gene reads in DNA extracted from biomass in waters pumped from NSHQ04 in 2018, which is similar to previous years of sampling at NSHQ04 (6\% to $18 \%$ in 2014, 2015, and 2017; inter-annual mean of $12 \%$ ) and higher than all other studied wells (Supporting Information Figure S3; (Rempfert et al., 2017; Miller et al., 2016; Kraus et al., 2021)).

While $\mathrm{H}_{2}$ has only been transiently detected at NSHQ04, $c_{\mathrm{CH}_{4}}$ at this well has consistently been the highest among our sample sites $\left(144 \mu \mathrm{mol} \cdot \mathrm{L}^{-1}\right.$ in 2018 and $483 \mu \mathrm{mol}$. $\mathrm{L}^{-1}$ in 2017. In comparison to NSHQ14, $\mathrm{CH}_{4}$ at NSHQ04 is more ${ }^{13} \mathrm{C}$ - and D-enriched (mean weighted by sample year $\delta^{13} \mathrm{C}=+3.3 \%$ VPDB, $s=1.8 \%$; $\delta \mathrm{D}=-220 \%$ VSMOW, $s=11 \% ; n=4$; Table 2; Figure 3a). Fluids sampled from NSHQ04 are in $\mathrm{CH}_{4}-$ $\mathrm{H}_{2} \mathrm{O}$ H isotopic disequilibrium and intra- $\mathrm{CH}_{4}$ disequilibrium (Figure $3 \mathrm{~b}$ and d), which is also true of fluids from NSHQ14. However, $\mathrm{CH}_{4}$ sampled from NSHQ04 has distinctly negative $\Delta^{12} \mathrm{CH}_{2} \mathrm{D}_{2}\left(-24.502 \%\right.$ ) and low $\Delta^{13} \mathrm{CH}_{3} \mathrm{D}$ (mean weighted by sample year of $0.36 \%, s=0.32 \%, n=3$; Table 2). As such, $\mathrm{CH}_{4}$ from NSHQ04 plots squarely among methanogen culture samples in $\Delta^{13} \mathrm{CH}_{3} \mathrm{D} / \Delta^{12} \mathrm{CH}_{2} \mathrm{D}_{2}$ space (Figure $3 \mathrm{~d}$ ), suggesting that $\mathrm{CH}_{4}$ is dominantly microbial at NSHQ04. Moreover, alkane gases dissolved in waters pumped from NSHQ04 exhibited a $\mathrm{C}_{1} /\left(\mathrm{C}_{2}+\mathrm{C}_{3}\right)$ ratio of $5.4 \cdot 10^{3}$ in 2018 , which is higher than 
other wells in this study (Table 4; Figure 3c), further supporting a major component of microbial $\mathrm{CH}_{4}$ at $\mathrm{NSHQ04}$.

Microbial $\mathrm{CH}_{4}$ production at NSHQ04 is also indicated by microbiological data. $16 \mathrm{~S}$ rRNA gene sequences affiliated with Methanobacterium have been detected in DNA extracted from biomass filtered from waters pumped from NSHQ04, albeit in low relative abundance $(<1 \%$ of reads in 2018; Figure 5; also detected in $<1 \%$ of reads in 2014, but not detected in 2015 and 2017; (Rempfert et al., 2017; Miller et al., 2016; Kraus et al., 2021)). The apparent low relative abundance of Methanobacterium at NSHQ04 could have resulted from the relatively shallow depth from which samples were collected at NSHQ04 due to well obstruction and the consequential sampling of groundwaters that may have experienced atmospheric $\mathrm{O}_{2}$ infiltration. High relative read abundances of sequences affiliated with aerobes and transient $\mathrm{H}_{2}$ across years of sampling NSHQ04 suggest that zones of the aquifer that are not always anoxic were accessed. These conditions may restrict methanogen abundance to greater depths than were sampled, but not constrain the upward diffusion of the product of their metabolism, $\mathrm{CH}_{4}$. Nevertheless, fluids obtained from NSHQ04 have yielded robust cultures of Methanobacterium (Miller et al., 2018). In addition, high relative abundances of $16 \mathrm{~S}$ rRNA gene reads of DNA extracted from biomass in waters sampled from NSHQ04 were related to an aerobic methanotroph of the genus Methylococcus (8\% of reads in 2018; inter-annual mean of $11 \%$; Figure 5; (Miller et al., 2016; Rempfert et al., 2017; Kraus et al., 2021)). Greater aerobic methanotrophy at NSHQ04 relative to NSHQ14 may have contributed in part to the lower $\Delta^{13} \mathrm{CH}_{3} \mathrm{D}$ and $\Delta^{12} \mathrm{CH}_{2} \mathrm{D}_{2}$ and higher $\delta^{13} \mathrm{C}$ and $\delta \mathrm{D}$ of $\mathrm{CH}_{4}$ sampled from NSHQ04.

Methanotrophic activity at NSHQ04 is consistent with the observed ${ }^{13} \mathrm{C}$-depletion in $\sum \mathrm{CO}_{2}$ at NSHQ04 $\left(-29.7 \%\right.$ VPDB $\delta^{13} \mathrm{C}$; Table 2) relative to the other studied wells because environments of active methanotrophy often have ${ }^{13} \mathrm{C}$-depleted $\sum \mathrm{CO}_{2}$ (Barker

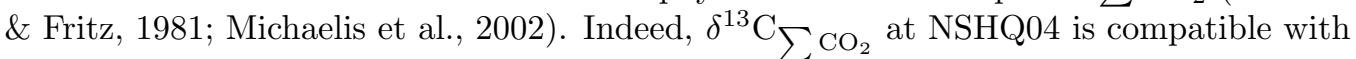
aerobic oxidation of $\mathrm{CH}_{4}$ of $\sim 0 \%$ VPDB $\delta^{13} \mathrm{C}$ (Barker \& Fritz, 1981; Feisthauer et al., 2011). Alternatively, ${ }^{13} \mathrm{C}$-depletion in $\sum \mathrm{CO}_{2}$ could be explained by kinetic isotope fractionation during hydroxylation of atmospheric $\mathrm{CO}_{2}$ upon contact with $\mathrm{Ca}^{2+}-\mathrm{OH}^{-}$water, which has been interpreted as the cause of $\delta^{13} \mathrm{C}$ as low as $-27.21 \% 0$ VPDB in Carich carbonates from hyperalkaline seeps in the Samail Ophiolite (Clark et al., 1992; P. B. Kelemen et al., 2011; Falk et al., 2016). Considering the relatively shallow sampling depth at NSHQ04 in 2018 (Table 1), it is plausible that the sampled groundwaters continuously interact with atmospheric $\mathrm{CO}_{2}$. Although the relative influences of methanotrophy and atmospheric $\mathrm{CO}_{2}$ hydroxylation cannot be determined based on the available data, both processes could affect $\delta^{13} \mathrm{C}_{\sum \mathrm{CO}_{2}}$ at NSHQ04.

In summary, low $\Delta^{13} \mathrm{CH}_{3} \mathrm{D}$ and $\Delta{ }^{12} \mathrm{CH}_{2} \mathrm{D}_{2}$, high $\mathrm{C}_{1} /\left(\mathrm{C}_{2}+\mathrm{C}_{3}\right)$, the presence of Methanobacterium that were readily cultured, and high $16 \mathrm{~S}$ rRNA gene relative abundances of Methylococcus lead us to conclude that microbial production and consumption of $\mathrm{CH}_{4}$ are the dominant factors controlling $\mathrm{CH}_{4}$ concentration and isotopic composition at NSHQ04.

\subsection{4 $\mathrm{H}_{2}$-limited microbial methanogenesis with classic $C$ isotope effect expressed at well WAB188}

WAB188 is situated $2 \mathrm{~km}$ down-gradient from NSHQ04 and is set in gabbro on the opposite side of a fault from NSHQ04 (Figure 1; Supporting Information Figure S1; Table 1). Fluids pumped from WAB188 have had variable $\mathrm{pH}$ (8.72 to 5.75) and oxidationreduction potential ( $f_{\mathrm{O}_{2}}$ of $10^{-61}$ bar to $10^{-34}$ bar and $E h$ of $-220 \mathrm{mV}$ to $+214 \mathrm{mV}$ ) across four years of sampling (Table 1; (Rempfert et al., 2017; Fones et al., 2019)). WAB188 has consistently had major ion compositions similar to the gabbro-hosted well WAB103, except that WAB188 has had higher $c_{\sum_{\mathrm{Ca}}}$ (Table 3; (Rempfert et al., 2017; Fones et al., 2019)). $\mathrm{H}_{2}$ has occasionally been detected in fluids pumped from WAB188 $\left(c_{\mathrm{H}_{2}}=\right.$ 
$0.992 \mu \mathrm{mol} \cdot \mathrm{L}^{-1}$ in 2017 ), and $\mathrm{CH}_{4}$ has consistently been detected at moderate concentrations $\left(c_{\mathrm{CH}_{4}}=1.83 \mu \mathrm{mol} \cdot \mathrm{L}^{-1}\right.$ in 2017 and $0.917 \mu \mathrm{mol} \cdot \mathrm{L}^{-1}$ in 2018) (Table 4; (Rempfert et al., 2017; Fones et al., 2019)). The high $c_{\sum_{\mathrm{Ca}}}$ and moderate but variable $\mathrm{pH}, E h$, and $c_{\mathrm{H}_{2}}$ in fluids sampled from WAB188 suggest that fluid chemical composition at WAB188 is dominantly controlled by water-rock reaction with gabbro (McCollom, 1999; Hoehler, 2004 ), but may also be affected by inputs of fresh rainwater and/or $\mathrm{H}_{2}$-bearing $\mathrm{Ca}^{2+}{ }_{-}$ $\mathrm{OH}^{-}$water flowing from the peridotite aquifer into the gabbro aquifer across a fault at depth. Flows of water from higher-head, lower-permeability peridotite aquifers into gabbro aquifers in the Samail Ophiolite have been proposed on the basis of physical hydrologic data (Dewandel et al., 2005). Instead or in addition, serpentinization of olivine and pyroxene entirely within gabbro might have produced $\mathrm{H}_{2}$ observed in water samples from WAB188.

Microbial methanogenesis at WAB188 is indicated by high relative abundances of $16 \mathrm{~S}$ rRNA gene reads affiliated with methanogens in pumped groundwaters. Sequences affiliated with Methanobacterium accounted for $3 \%$ of $16 \mathrm{~S}$ rRNA gene reads of DNA extracted from subsurface fluids sampled from WAB188 in 2018, which was second only to NSHQ14 among our sampling sites, and consistent with prior years of sampling at WAB188 (mean 2015 to 2018 of 4\%; Figure 5; (Rempfert et al., 2017; Kraus et al., 2021)). There was also evidence for methanotrophy. $2 \%$ of $16 \mathrm{~S}$ rRNA gene reads from WAB188 were affiliated with Methylococcus in 2018, which was second only to NSHQ04 among our sampling sites, and consistent with prior years of sampling (Figure 5; (Rempfert et al., 2017; Kraus et al., 2021)). Further, 16S rRNA gene sequences affiliated with genus Candidatus Methylomirabilis, which includes species that mediate anaerobic methane oxidation coupled to nitrite reduction (Ettwig et al., 2010; Luesken et al., 2012; Welte et al., 2016), were detected in samples from WAB188 in 2018 albeit at low relative gene abundance $(<1 \%)$. As a whole, the 16S rRNA gene sequencing data from WAB188 fluids are consistent with microbial production of $\mathrm{CH}_{4}$ and, secondarily, methanotrophy using $\mathrm{O}_{2}$ and/or $\mathrm{NO}_{2}^{-}$. The $16 \mathrm{~S}$ rRNA data are bolstered by genomic and cultivation data that demonstrate that Methanobacterium at WAB188 can produce $\mathrm{CH}_{4}$ from $\mathrm{CO}_{2}$ and/or formate (Fones et al., 2020) and that genes involved in methanogenesis are transcribed in groundwater samples obtained from WAB188 (Kraus et al., 2021).

While subsurface fluids sampled at WAB188, NSHQ14, and NSHQ04 all bear evidence of methanogenic activity, the conditions under which methanogenesis proceeds at WAB188 are fundamentally distinct. In contrast to the $\mathrm{Ca}^{2+}-\mathrm{OH}^{-}$fluids from NSHQ14 and NSHQ04, the circumneutral fluids from WAB188 have $\sim 10^{2}$ to $\sim 10^{3}$ times higher $c_{\sum \mathrm{CO}_{2}}$ (inter-annual mean of $2910 \mu \mathrm{mol} \cdot \mathrm{L}^{-1}, s=620 \mu \mathrm{mol} \cdot \mathrm{L}^{-1}, n=3$; Table 3 ) and $\sim 75 \%$ o lower $\delta^{13} \mathrm{C}_{\mathrm{CH}_{4}}$ (inter-annual mean $\delta^{13} \mathrm{C}=-73 \%$ VPDB, $s=13 \%, n=3$; Table 2; Figure S5). Since WAB188 fluids contain relatively ${ }^{13} \mathrm{C}$-depleted $\mathrm{CH}_{4}$ that is not associated with substantial concentrations of $\mathrm{C}_{2}-\mathrm{C}_{6}$ alkanes (Table 4), a standard interpretation (Bernard et al., 1977; Milkov \& Etiope, 2018) would be that the source of $\mathrm{CH}_{4}$ at WAB188 is dominantly microbial. Such an interpretation is largely based on data from sedimentary settings, where $\mathrm{H}_{2}$ is typically more scarce than $\mathrm{CO}_{2}$. In this regard, conditions in sedimentary settings are analogous to those at WAB188. Evidence that considerable methanogenesis proceeds through a hydrogenotrophic pathway under $\mathrm{H}_{2}$-limited conditions at WAB188 include microbiological data confirming the capacity of Methanobacterium to perform hydrogenotrophic methanogenesis at WAB188 and thermodynamic calculations showing that hydrogenotrophic methanogenesis (with $\mathrm{H}_{2}$ as limiting substrate) was more energetically favorable than formatotrophic methanogenesis for a fluid with $c_{\sum \mathrm{CO}_{2}}$ and $c_{\mathrm{H}_{2}}$ similar to WAB188 in 2017 (Section 4.2.1; Table 5). Further, the apparent $\alpha_{\mathrm{CO}_{2} / \mathrm{CH}_{4}}$ at WAB188 (based on measured $\delta^{13} \mathrm{C}_{\sum \mathrm{CO}_{2}}$ of $-13.52 \%$ VPDB; Table 3) is compatible with that of Methanobacterium cultures grown hydrogenotrophically with excess $\mathrm{HCO}_{3}^{-}(\mathrm{aq})$, which was greater than the $\alpha_{\mathrm{CO}_{2} / \mathrm{CH}_{4}}$ observed for parallel cultures under $\mathrm{CO}_{2}$-poor conditions (Miller et al., 2018). In sum, the conditions at 


\section{Conclusions}

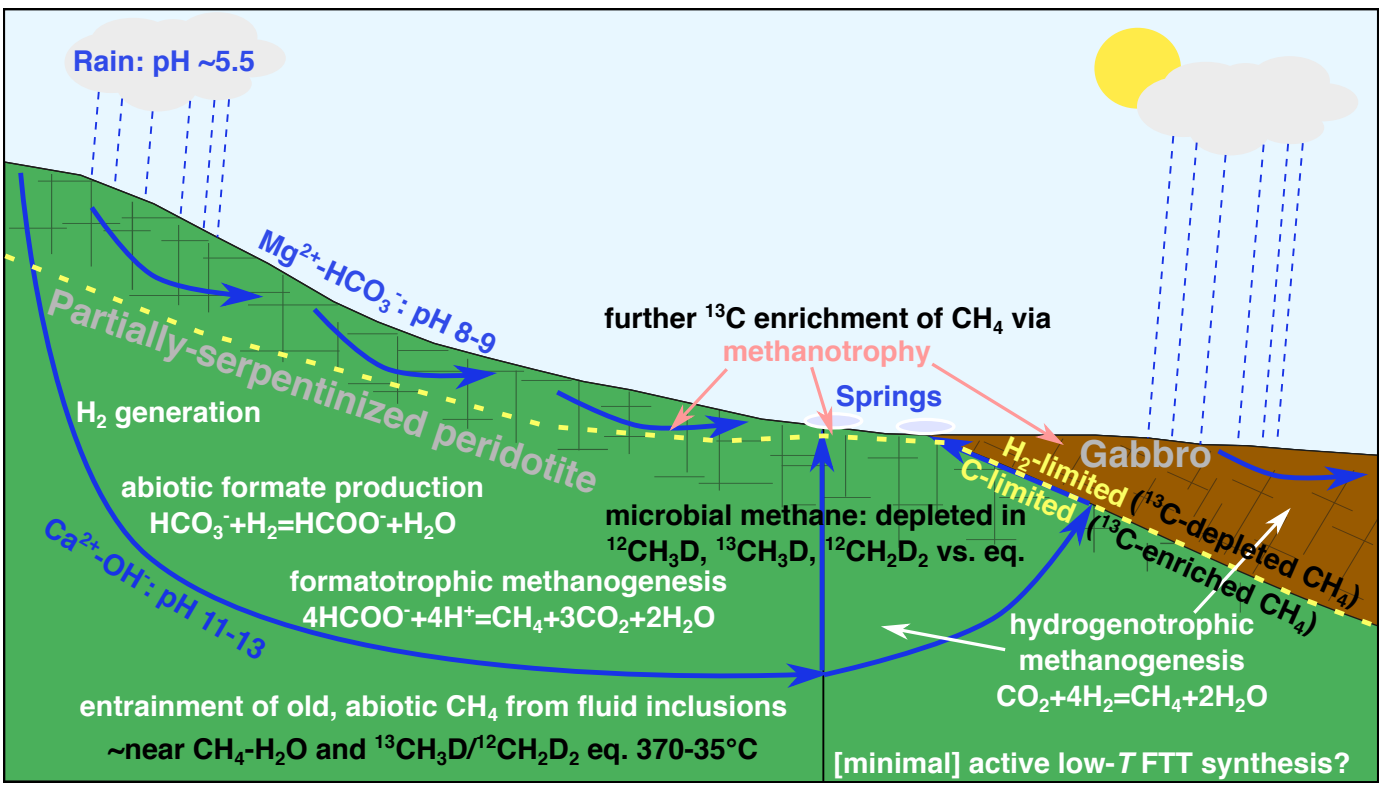

Figure 6. Conceptual model of $\mathrm{CH}_{4}$ dynamics in Samail Ophiolite. Cross section after Neal and Stanger (1985), Dewandel et al. (2005), and Rempfert et al. (2017). Groundwater flow is depicted with blue arrows. Cross-hatching illustrates fissured zone of aquifer, extending to $\sim 50 \mathrm{~m}$ depth. A deep tectonic fracture hosting upward groundwater flow is shown as a black line. Yellow dashed line indicates proposed transition between conditions where methanogenesis is limited by $\mathrm{H}_{2}$ versus $\mathrm{C}$ availability. Isotopic systematics are written in black text. Abbreviations: eq.,

equilibrium; T, temperature; FTT, Fischer-Tropsch-type.

WAB188 contrast starkly with those that prevail in $\mathrm{Ca}^{2+}-\mathrm{OH}^{-}$fluids, where $\mathrm{C}$ subtrates for methanogenesis are often more scarce than $\mathrm{H}_{2}$. These differences may be reflected in the inverse relationship between ${ }^{c} \sum_{\mathrm{CO}_{2}}$ and $\delta^{13} \mathrm{C}_{\mathrm{CH}_{4}}$ across fluids from wells
WAB188, NSHQ14, and NSHQ04 (Figure S5), which is consistent with an effect of C availability on the apparent $\mathrm{C}$ isotope effect of microbial methanogenesis.

Through integration of isotopic, microbiological, and hydrogeochemical data, we conclude that substantial microbial $\mathrm{CH}_{4}$ is produced under varying degrees of $\mathrm{C}$ or $\mathrm{H}_{2}$ limitation in subsurface waters of the Samail Ophiolite and mixes with abiotic $\mathrm{CH}_{4}$ released from fluid inclusions (Figure 6). Across subsurface fluids ranging in $\mathrm{pH}$ from circumneutral to 11.39 , microbial $\mathrm{CH}_{4}$ production is evidenced by $16 \mathrm{~S}$ rRNA gene sequencing and other microbiological data indicating that methanogens are widespread and active in groundwaters in the ophiolite. We propose that $\mathrm{CH}_{4}$ produced by these microbes constitutes a substantial portion of the total $\mathrm{CH}_{4}$ pool, which is consistent with our finding of ${ }^{13} \mathrm{CH}_{3} \mathrm{D}$ and ${ }^{12} \mathrm{CH}_{2} \mathrm{D}_{2}$ relative abundances significantly less than equilibrium. Using a simple thermodynamic model, we find that formatotrophic methanogenesis may become more energetically favorable than hydrogenotrophic methanogenesis as $\mathrm{Mg}^{2+}-$ $\mathrm{HCO}_{3}^{-}$waters transition to $\mathrm{Ca}^{2+}-\mathrm{OH}^{-}$waters where $\mathrm{CO}_{2}(\mathrm{aq})$ is extremely scarce, despite relatively low formate concentrations of $\sim 1 \mu \mathrm{mol} \cdot \mathrm{L}^{-1}$ across fluid types (Rempfert et al., 2017). This lends geochemical support to recent microbiological findings that independently indicate that the activity of formatotrophic methanogens increases relative 
to hydrogenotrophic methanogens as groundwater $\mathrm{pH}$ increases in the ophiolite (Fones et al., 2020).

In addition, an abiotic, fluid inclusion-derived source of $\mathrm{CH}_{4}, \mathrm{C}_{2} \mathrm{H}_{6}$, and $\mathrm{C}_{3} \mathrm{H}_{8}$ is inferred from the widespread occurrence of $\mathrm{CH}_{4}$ in fluid inclusions in peridotites, including those in Oman, and is supported by the relatively ${ }^{13} \mathrm{C}$-enriched compositions of $\mathrm{CH}_{4}$, $\mathrm{C}_{2} \mathrm{H}_{6}$, and $\mathrm{C}_{3} \mathrm{H}_{8}$ measured in gases exsolved from peridotite-hosted groundwaters in this study. The measured $\delta^{13} \mathrm{C}$ values overlap with those of $\mathrm{CH}_{4}, \mathrm{C}_{2} \mathrm{H}_{6}$ and $\mathrm{C}_{3} \mathrm{H}_{8}$ from seafloor hydrothermal vents where fluid inclusions are the dominant source of these alkanes, suggesting similar $\mathrm{CH}_{4}$ sources across these environments. In contrast, abiotic, low-temperature reduction of $\mathrm{CO}_{2}$ to $\mathrm{CH}_{4}$ appears less likely to contribute substantially to the $\mathrm{CH}_{4}$ pool in the study area due to a scarcity of conditions favorable to catalysis, namely, access of gas-phase $\mathrm{H}_{2}$ and $\mathrm{CO}_{2} / \mathrm{CO}$ to $\mathrm{Ru}$-bearing chromites.

Further, we note an inverse relationship between $c \sum_{\mathrm{CO}_{2}}$ and $\delta^{13} \mathrm{C}_{\mathrm{CH}_{4}}$ across groundwaters bearing microbiological evidence of methanogenic activity. This finding supports the hypothesis that the apparent $\mathrm{C}$ isotope fractionation between the $\mathrm{C}$ substrate used by methanogens and the $\mathrm{CH}_{4}$ they produce is suppressed when the $\mathrm{C}$ substrate is limiting. Thus, our finding that $\delta^{13} \mathrm{C}_{\mathrm{CH}_{4}}$ varies by $90 \%$ in the Samail Ophiolite suggests that, in some settings, $\delta^{13} \mathrm{C}_{\mathrm{CH}_{4}}$ may be a powerful indicator of transitions from $\mathrm{H}_{2}$-limited to C-limited conditions for microbial methanogenesis, rather than a discriminant between microbial versus abiotic $\mathrm{CH}_{4}$. The $16 \mathrm{~S}$ rRNA gene sequencing data also indicate the presence of microbes capable of $\mathrm{CH}_{4}$ oxidation, particularly those that can use $\mathrm{O}_{2}$ as an oxidant. This oxidation may also contribute in part to the ${ }^{13} \mathrm{C}$-enriched composition of $\mathrm{CH}_{4}$ in the ophiolite, which is considered unusual for $\mathrm{CH}_{4}$ with a substantial microbial component.

This study supports the premise that $\mathrm{H}_{2}$ produced from water/rock reaction can fuel microbial life, even under challenging conditions of high $\mathrm{pH}$ and low oxidant availability. By identifying where and how microbial methanogenesis can reasonably be expected to occur in $\mathrm{H}_{2}$-rich, subsurface environments, this work complements theoretical models in guiding the search for rock-hosted life, including extraterrestrial life. For example, our findings substantiate predictions that microbial methanogenesis could occur in the reduced, alkaline ocean of Saturn's moon, Enceladus (McKay et al., 2008; Glein et al., 2015; Waite et al., 2017) and in the Martian subsurface (Kral et al., 2014).

\section{Open Research}

Data (in Excel format) and source code (in R Markdown format) used to produce the figures, data tables and analyses for this paper (as well as additional data on analytical uncertainties and trace element concentrations) are available online in D. B. Nothaft, Templeton, et al. (2021). Additional DNA sequence data processing codes are available in D. B. Nothaft, Rempfert, and Kraus (2021). The sequences are accessible on the NCBI Short Read Archive under accession PRJNA655565.

\section{Acknowledgments}

This research was directly supported by the Rock-Powered Life NASA Astrobiology Institute (NNA15BB02A). This research also used samples and/or data provided by the Oman Drilling Project. The Oman Drilling Project (OmanDP) has been possible through co-mingled funds from the International Continental Scientific Drilling Project (ICDP), the Sloan Foundation - Deep Carbon Observatory (Grant 2014-3-01, Kelemen PI), the National Science Foundation (NSF-EAR-1516300, Kelemen PI), the NASA Astrobiology Institute (NNA15BB02A), the German Research Foundation (DFG), the Japanese Society for the Promotion of Science (JSPS), the European Research Council, the Swiss National Science Foundation, JAMSTEC, the TAMU-JR Science operator, and contri- 
butions from the Sultanate of Oman Ministry of Regional Municipalities and Water Resources, the Oman Public Authority of Mining, Sultan Qaboos University, CRNS-Univ. Montpellier II, Columbia University, and the University of Southampton. Work at LBNL was supported by the U.S. Department of Energy, Office of Science, Office of Basic Energy Sciences, Chemical Sciences, Geosciences, and Biosciences Division, under Award Number DE-AC02-05CH11231.

We thank the Ministry of Regional Municipalities and Water Resources in the Sultanate of Oman (particularly Said Al Habsi, Rashid Al Abri, Salim Al Khanbashi, and Haider Ahmed Mohammed Alajmi) for allowing access to wells and logistical support, Zaher Al Sulaimani and Mazin Al Sulaimani from the Oman Water Centre and AZD Engineering for their technical and logistical support, Jude Coggon for coordinating Oman Drilling Project activities, Benoît Ildefonse for sharing geologic map data, Eric Ellison and Kaitlin Rempfert for their assistance in the field and laboratory, Elizabeth Fones for sharing biomass samples, Emily Kraus for critical discussion of $\mathrm{Oman}_{\mathrm{CH}}$ cycle processes, and Noah Fierer, Jen Reeves, Corinne Walsh, Matthew Gebert, and Angela Oliverio for assisting with DNA sequencing and interpretation.

\section{References}

Abrajano, T., Sturchio, N., Kennedy, B., Lyon, G., Muehlenbachs, K., \& Bohlke, J. (1990). Geochemistry of reduced gas related to serpentinization of the Zambales ophiolite, Philippines. Appl. Geochem., 5(5),625 - 630. Retrieved from http://www.sciencedirect.com/science/article/pii/088329279090060I (Water-Rock Interactions Special Memorial Issue Ivan Barnes (1931-1989)) doi: 10.1016/0883-2927(90)90060-I

Alsharhan, A. S. (1989). PETROLEUM GEOLOGY OF THE UNITED ARAB EMIRATES. J. Pet. Geol., 12(3), 253-288. Retrieved from https:// onlinelibrary.wiley.com/doi/abs/10.1111/j.1747-5457.1989.tb00197.x doi: $10.1111 /$ j.1747-5457.1989.tb00197.x

Alt, J. C., Garrido, C. J., Shanks, W., Turchyn, A., Padrón-Navarta, J. A., SánchezVizcaíno, V. L., .. Marchesi, C. (2012). Recycling of water, carbon, and sulfur during subduction of serpentinites: A stable isotope study of Cerro del Almirez, Spain. Earth Planet. Sci. Lett., 327-328, 50 - 60. Retrieved from http://www.sciencedirect.com/science/article/pii/S0012821X12000568 doi: $10.1016 /$ j.epsl.2012.01.029

Alt, J. C., Schwarzenbach, E. M., Früh-Green, G. L., Shanks, W. C., Bernasconi, S. M., Garrido, C. J., ... Marchesi, C. (2013). The role of serpentinites in cycling of carbon and sulfur: Seafloor serpentinization and subduction metamorphism. Lithos, 178, 40 - 54. Retrieved from http://www. sciencedirect.com/ science/article/pii/S0024493712004975 (Serpentinites from mid-oceanic ridges to subduction) doi: 10.1016/j.lithos.2012.12.006

Alt, J. C., Shanks, W., Crispini, L., Gaggero, L., Schwarzenbach, E. M., FrühGreen, G. L., \& Bernasconi, S. M. (2012). Uptake of carbon and sulfur during seafloor serpentinization and the effects of subduction metamorphism in Ligurian peridotites. Chem. Geol., 322-323, 268 - 277. Retrieved from http://www.sciencedirect.com/science/article/pii/S0009254112003154 doi: $10.1016 /$ j.chemgeo.2012.07.009

Ash, J. L., \& Egger, M. (2019, Jun). Exchange catalysis during anaerobic methanotrophy revealed by ${ }^{12} \mathrm{CH}_{2} \mathrm{D}_{2}$ and ${ }^{13} \mathrm{CH}_{3} \mathrm{D}$ in methane. Geochem. Perspect. Lett., 10, 26-30. Retrieved from https://www .geochemicalperspectivesletters.org/article1910 doi: 10.7185/ geochemlet.1910

Assayag, N., Rivé, K., Ader, M., Jézéquel, D., \& Agrinier, P. (2006). Improved method for isotopic and quantitative analysis of dissolved inorganic carbon in 
natural water samples.

Rapid Commun. Mass Spectrom., 20(15), 2243-2251. doi: $10.1002 / \mathrm{rcm} .2585$

Bach, W., Paulick, H., Garrido, C. J., Ildefonse, B., Meurer, W. P., \& Humphris, S. E. (2006). Unraveling the sequence of serpentinization reactions: petrography, mineral chemistry, and petrophysics of serpentinites from MAR $15^{\circ} \mathrm{N}$ (ODP Leg 209, Site 1274). Geophys. Res. Lett., 33(13). Retrieved from https://agupubs.onlinelibrary.wiley.com/doi/abs/10.1029/ 2006GL025681 doi: 10.1029/2006GL025681

Balch, W. E., Fox, G. E., Magrum, L. J., Woese, C. R., \& Wolfe, R. S. (1979, Jun). Methanogens: reevaluation of a unique biological group. Microbiol. Rev., 43(2), 260. Retrieved from https://www.ncbi.nlm.nih.gov/pmc/articles/ PMC281474

Barker, J. F., \& Fritz, P. (1981, Sep). Carbon isotope fractionation during microbial methane oxidation. Nature, 293(5830), 289-291. doi: 10.1038/293289a0

Barnes, I., LaMarche, j. V., \& Himmelberg, G. (1967). Geochemical evidence of present-day serpentinization. Science, $156(3776), 830-832 . \quad$ doi: 10.1126/ science. 156.3776 .830

Barnes, I., O'Neil, J., \& Trescases, J. (1978). Present day serpentinization in New Caledonia, Oman and Yugoslavia. Geochim. Cosmochim. Acta, 42(1), 144 145. Retrieved from http://www.sciencedirect.com/science/article/pii/ 0016703778902259 doi: 10.1016/0016-7037(78)90225-9

Barnes, I., \& O'Neil, J. R. (1969). The relationship between fluids in some fresh alpine-type ultramafics and possible modern serpentinization, western United States. Geol. Soc. Am. Bull., 80(10), 1947-1960. doi: 10.1130/ 0016-7606(1969)80[1947:TRBFIS]2.0.CO;2

Bernard, B., Brooks, J. M., Sackett, W. M., et al. (1977). A geochemical model for characterization of hydrocarbon gas sources in marine sediments. In Offshore technology conference (p. 435-438). doi: 10.4043/2934-MS

Boetius, A., Ravenschlag, K., Schubert, C. J., Rickert, D., Widdel, F., Gieseke, A., ... Pfannkuche, O. (2000). A marine microbial consortium apparently mediating anaerobic oxidation of methane. Nature, 407(6804), 623-626. Retrieved from https://doi.org/10.1038/35036572 doi: 10.1038/35036572

Boone, D. R. (2015). Methanobacterium. In Bergey's manual of systematics of archaea and bacteria (p. 1-8). American Cancer Society. Retrieved from https://onlinelibrary.wiley.com/doi/abs/10.1002/ 9781118960608.gbm00495 doi: 10.1002/9781118960608.gbm00495

Bottinga, Y. (1969). Calculated fractionation factors for carbon and hydrogen isotope exchange in the system calcite-carbon dioxide-graphite-methanehydrogen-water vapor. Geochim. Cosmochim. Acta, 33(1), 49 - 64 . Retrieved from http://www.sciencedirect.com/science/article/pii/ 0016703769900921 doi: 10.1016/0016-7037(69)90092-1

Boudier, F., Baronnet, A., \& Mainprice, D. ～(2009, Aug). Serpentine Mineral Replacements of Natural Olivine and their Seismic Implications: Oceanic Lizardite versus Subduction-Related Antigorite. J. Petrol., 51(1-2), 495-512. doi: $10.1093 /$ petrology/egp049

Boudier, F., \& Coleman, R. G. (1981). Cross section through the peridotite in the Samail Ophiolite, southeastern Oman Mountains. J. Geophys. Res.: Solid Earth, 86(B4), 2573-2592. Retrieved from https:// agupubs. onlinelibrary.wiley.com/doi/abs/10.1029/JB086iB04p02573 doi: $10.1029 / J B 086 \mathrm{iB} 04 \mathrm{p} 02573$

Boulart, C., Chavagnac, V., Monnin, C., Delacour, A., Ceuleneer, G., \& Hoareau, G. (2013). Differences in gas venting from ultramafic-hosted warm springs: the example of Oman and Voltri ophiolites. Ofioliti, 38(2), 142-156. doi: 10.4454/ofioliti.v38i2.423

Bradley, A. S., Hayes, J. M., \& Summons, R. E. $\quad$ (2009). Extraordinary ${ }^{13}$ C en- 
richment of diether lipids at the Lost City Hydrothermal Field indicates a carbon-limited ecosystem. Geochim. Cosmochim. Acta, 73(1), 102-118. doi: 10.1016/j.gca.2008.10.005

Brazelton, W. J., Thornton, C. N., Hyer, A., Twing, K. I., Longino, A. A., Lang, S. Q., .. Schrenk, M. O. (2017). Metagenomic identification of active methanogens and methanotrophs in serpentinite springs of the Voltri Massif, Italy. PeerJ, 5, e2945. doi: 10.7717/peerj.2945

Bruni, J., Canepa, M., Chiodini, G., Cioni, R., Cipolli, F., Longinelli, A., ... Zuccolini, M. V. (2002). Irreversible water-rock mass transfer accompanying the generation of the neutral, $\mathrm{Mg}-\mathrm{HCO} 3$ and high- $\mathrm{pH}, \mathrm{Ca}-\mathrm{OH}$ spring waters of the Genova province, Italy. Appl. Geochem., 17(4), 455-474. doi: 10.1016/S0883-2927(01)00113-5

Burnham, A. K. $\quad(1989,3) . \quad$ A simple kinetic model of petroleum formation and cracking (Tech. Rep. No. UCID-21665). Lawrence Livermore National Lab., CA (USA). Retrieved from https://www.osti.gov/biblio/6189092

Callahan, B. J., McMurdie, P. J., Rosen, M. J., Han, A. W., Johnson, A. J. A., \& Holmes, S. P. (2016, May). DADA2: High-resolution sample inference from Illumina amplicon data. Nat. Methods, 13(7), 581. doi: 10.1038/nmeth.3869

Canovas III, P. A., Hoehler, T., \& Shock, E. L. (2017). Geochemical bioenergetics during low-temperature serpentinization: An example from the Samail ophiolite, Sultanate of Oman. J. Geophys. Res.: Biogeosci., 122(7), 1821-1847. doi: 10.1002/2017JG003825

Charlou, J., Donval, J., Douville, E., Jean-Baptiste, P., Radford-Knoery, J., Fouquet, Y., ... Stievenard, M. (2000). Compared geochemical signatures and the evolution of Menez Gwen $\left(37^{\circ} 50^{\prime} \mathrm{N}\right)$ and Lucky Strike $\left(37^{\circ} 17^{\prime} \mathrm{N}\right)$ hydrothermal fluids, south of the Azores Triple Junction on the Mid-Atlantic Ridge. Chem. Geol., 171(1), 49 - 75. Retrieved from http://www.sciencedirect.com/science/article/pii/S0009254100002448 doi: 10.1016/S0009-2541(00)00244-8

Charlou, J., Donval, J., Fouquet, Y., Jean-Baptiste, P., \& Holm, N. (2002). Geochemistry of high $\mathrm{H}_{2}$ and $\mathrm{CH}_{4}$ vent fluids issuing from ultramafic rocks at the Rainbow hydrothermal field ( $\left.36^{\circ} 14^{\prime} \mathrm{N}, \mathrm{MAR}\right)$. Chem. Geol., 191(4), 345-359. doi: 10.1016/S0009-2541(02)00134-1

Charlou, J. L., Donval, J. P., Konn, C., Ondréas, H., Fouquet, Y., Jean-Baptiste, P., \& Fourré, E. (2010). High production and fluxes of $\mathrm{H}_{2}$ and $\mathrm{CH}_{4}$ and evidence of abiotic hydrocarbon synthesis by serpentinization in ultramafic-hosted hydrothermal systems on the Mid-Atlantic Ridge. In Diversity of hydrothermal systems on slow spreading ocean ridges (p. 265-296). American Geophysical Union (AGU). Retrieved from https://agupubs.onlinelibrary.wiley.com/ doi/abs/10.1029/2008GM000752 doi: 10.1029/2008GM000752

Charlou, J. L., Fouquet, Y., Donval, J. P., Auzende, J. M., Jean-Baptiste, P., Stievenard, M., \& Michel, S. (1996). Mineral and gas chemistry of hydrothermal fluids on an ultrafast spreading ridge: East Pacific Rise, $17^{\circ}$ to $19^{\circ} \mathrm{S}$ (Naudur cruise, 1993) phase separation processes controlled by volcanic and tectonic activity. J. Geophys. Res.: Solid Earth, 101(B7), 15899-15919. Retrieved from https://agupubs . onlinelibrary.wiley.com/doi/abs/10.1029/96JB00880 doi: $10.1029 / 96 J B 00880$

Charlton, S. R., \& Parkhurst, D. L. (2011). Modules based on the geochemical model PHREEQC for use in scripting and programming languages. Comput. Geosci., 37(1653-1663). doi: 10.1016/j.cageo.2011.02.005

Chavagnac, V., Ceuleneer, G., Monnin, C., Lansac, B., Hoareau, G., \& Boulart, C. (2013). Mineralogical assemblages forming at hyperalkaline warm springs hosted on ultramafic rocks: A case study of Oman and Ligurian ophiolites. Geochem., Geophys., Geosyst., 14(7), 2474-2495. Retrieved from https://agupubs.onlinelibrary.wiley.com/doi/abs/10.1002/ggge. 20146 
doi: 10.1002/ggge.20146

Chavagnac, V., Monnin, C., Ceuleneer, G., Boulart, C., \& Hoareau, G. Characterization of hyperalkaline fluids produced by low-temperature serpentinization of mantle peridotites in the Oman and Ligurian ophiolites. Geochem., Geophys., Geosyst., 14(7), 2496-2522. doi: 10.1002/ggge.20147

Cipolli, F., Gambardella, B., Marini, L., Ottonello, G., \& Zuccolini, M. V. (2004). Geochemistry of high-pH waters from serpentinites of the Gruppo di Voltri (Genova, Italy) and reaction path modeling of $\mathrm{CO}_{2}$ sequestration in serpentinite aquifers. Appl. Geochem., 19(5), 787 - $802 . \quad$ Retrieved from http://www.sciencedirect.com/science/article/pii/S0883292703002105 doi: 10.1016/j.apgeochem.2003.10.007

Clark, I. D., Fontes, J.-C., \& Fritz, P. (1992). Stable isotope disequilibria in travertine from high $\mathrm{pH}$ waters: Laboratory investigations and field observations from Oman. Geochim. Cosmochim. Acta, 56(5), 2041 - 2050. Retrieved from http://www.sciencedirect.com/science/article/pii/001670379290328G doi: 10.1016/0016-7037(92)90328-G

Coleman, R. G., \& Hopson, C. A. (1981). Introduction to the Oman Ophiolite Special Issue. J. Geophys. Res.: Solid Earth, 86(B4), 2495-2496. Retrieved from https://agupubs.onlinelibrary.wiley.com/doi/abs/10.1029/ JB086iB04p02495 doi: 10.1029/JB086iB04p02495

Collier, M. L. (2012). Spatial-Statistical Properties of Geochemical Variability as Constraints on Magma Transport and Evolution Processes at Ocean Ridges (Doctoral dissertation, Columbia University). doi: 10.7916/D82V2P43

Crespo-Medina, M., Twing, K. I., Sánchez-Murillo, R., Brazelton, W. J., McCollom, T. M., \& Schrenk, M. O. (2017, May). Methane Dynamics in a Tropical Serpentinizing Environment: The Santa Elena Ophiolite, Costa Rica. Front. Microb., 8. Retrieved from http://dx.doi.org/10.3389/fmicb.2017.00916 doi: 10.3389 /fmicb.2017.00916

Cumming, E. A., Rietze, A., Morrissey, L. S., Cook, M. C., Rhim, J. H., Ono, S., \& Morrill, P. L. (2019). Potential sources of dissolved methane at the Tablelands, Gros Morne National Park, NL, CAN: A terrestrial site of serpentinization. Chem. Geol., 514, 42 - 53. Retrieved from http:// www.sciencedirect.com/science/article/pii/S0009254119301299 doi: 10.1016/j.chemgeo.2019.03.019

de Obeso, J. C., \& Kelemen, P. B. (2018). Fluid rock interactions on residual mantle peridotites overlain by shallow oceanic limestones: Insights from Wadi Fins, Sultanate of Oman. Chem. Geol., 498, 139 - 149. Retrieved from http://www.sciencedirect.com/science/article/pii/S0009254118304625 doi: $10.1016 /$ j.chemgeo.2018.09.022

Deines, P. (2002). The carbon isotope geochemistry of mantle xenoliths. Earth-Sci. Rev., 58(3), $247-278 . \quad$ Retrieved from http://www.sciencedirect.com/ science/article/pii/S0012825202000648 doi: 10.1016/S0012-8252(02) 00064-8

Delacour, A., Früh-Green, G. L., Bernasconi, S. M., Schaeffer, P., \& Kelley, D. S. (2008). Carbon geochemistry of serpentinites in the Lost City Hydrothermal System $\left(30^{\circ} \mathrm{N}, \mathrm{MAR}\right)$. Geochim. Cosmochim. Acta, 72(15), $3681-3702$. Retrieved from http://www.sciencedirect.com/science/article/pii/ S0016703708002585 doi: 10.1016/j.gca.2008.04.039

Dewandel, B., Boudier, F., Kern, H., Warsi, W., \& Mainprice, D. $\quad$ (2003). $\quad$ Seismic wave velocity and anisotropy of serpentinized peridotite in the Oman ophiolite. Tectonophysics, 370(1), 77 - 94. Retrieved from http:// www.sciencedirect.com/science/article/pii/S0040195103001781 (Physical Properties of Rocks and other Geomaterials, a Special Volume to honour Professor H. Kern) doi: 10.1016/S0040-1951(03)00178-1

Dewandel, B., Lachassagne, P., Boudier, F., Al-Hattali, S., Ladouche, B., Pinault, J.- 
L., \& Al-Suleimani, Z. (2005, 5). A conceptual hydrogeological model of ophiolite hard-rock aquifers in Oman based on a multiscale and a multidisciplinary approach. Hydrogeol. J., 13(5-6), 708-726. doi: 10.1007/s10040-005-0449-2

Etiope, G. (2017). Methane origin in the Samail ophiolite: Comment on "Modern water/rock reactions in Oman hyperalkaline peridotite aquifers and implications for microbial habitability" [Geochim. Cosmochim. Acta 179 (2016) 217-241]. Geochim. Cosmochim. Acta, 197, 467 - 470. Retrieved from http://www.sciencedirect.com/science/article/pii/S0016703716304379 doi: $10.1016 /$ j.gca.2016.08.001

Etiope, G., Ifandi, E., Nazzari, M., Procesi, M., Tsikouras, B., Ventura, G., ... Szatmari, P. (2018, Jun). Widespread abiotic methane in chromitites. Sci. Rep., 8(1). Retrieved from http://dx.doi.org/10.1038/s41598-018-27082-0 doi: $10.1038 / \mathrm{s} 41598-018-27082-0$

Etiope, G., \& Ionescu, A. (2015). Low-temperature catalytic $\mathrm{CO}_{2}$ hydrogenation with geological quantities of ruthenium: a possible abiotic $\mathrm{CH}_{4}$ source in chromitite-rich serpentinized rocks. Geofluids, 15(3), 438-452. doi: $10.1111 /$ gfl.12106

Etiope, G., Judas, J., \& Whiticar, M. (2015). Occurrence of abiotic methane in the eastern United Arab Emirates ophiolite aquifer. Arabian J. Geosci., 8(12), 11345-11348. doi: 10.1007/s12517-015-1975-4

Etiope, G., Vadillo, I., Whiticar, M., Marques, J., Carreira, P., Tiago, I., ... Urresti, B. (2016). Abiotic methane seepage in the Ronda peridotite massif, southern Spain. Appl. Geochem., 66, 101-113. doi: doi.org/10.1016/ j.apgeochem.2015.12.001

Etiope, G., \& Whiticar, M. (2019). Abiotic methane in continental ultramafic rock systems: Towards a genetic model. Appl. Geochem., 102, 139 - 152. Retrieved from http://www.sciencedirect.com/science/article/pii/ S0883292719300204 doi: 10.1016/j.apgeochem.2019.01.012

Ettwig, K. F., Butler, M. K., Le Paslier, D., Pelletier, E., Mangenot, S., Kuypers, M. M. M., ... Strous, M. (2010, Mar). Nitrite-driven anaerobic methane oxidation by oxygenic bacteria. Nature, 464(7288), 543 . doi: 10.1038/ nature 08883

Evans, B. W. (1977). Metamorphism of alpine peridotite and serpentinite. Annu. Rev. Earth Planet. Sci., 5(1), 397-447. Retrieved from https://doi.org/10.1146/annurev.ea.05.050177.002145 doi: 10.1146/ annurev.ea.05.050177.002145

Falk, E., Guo, W., Paukert, A., Matter, J., Mervine, E., \& Kelemen, P. (2016). Controls on the stable isotope compositions of travertine from hyperalkaline springs in Oman: Insights from clumped isotope measurements. Geochim. Cosmochim. Acta, 192, 1 - 28. Retrieved from http://www.sciencedirect.com/ science/article/pii/S0016703716303568 doi: 10.1016/j.gca.2016.06.026

Feisthauer, S., Vogt, C., Modrzynski, J., Szlenkier, M., Krüger, M., Siegert, M., \& Richnow, H.-H. (2011). Different types of methane monooxygenases produce similar carbon and hydrogen isotope fractionation patterns during methane oxidation. Geochim. Cosmochim. Acta, 75(5), 1173 - $1184 . \quad$ Retrieved from http://www.sciencedirect.com/science/article/pii/S0016703710006691 doi: $10.1016 /$ j.gca.2010.12.006

Fiebig, J., Stefánsson, A., Ricci, A., Tassi, F., Viveiros, F., Silva, C., ... Mountain, B. W. (2019). Abiogenesis not required to explain the origin of volcanichydrothermal hydrocarbons. Geochem. Perspect. Lett., 11, 23-27. Retrieved from http://www.geochemicalperspectivesletters.org/article1920 doi: 10.7185/geochemlet.1920

Fones, E. M., Colman, D. R., Kraus, E. A., Nothaft, D. B., Poudel, S., Rempfert, K. R., ... Boyd, E. S. (2019). Physiological adaptations to serpentinization in the Samail Ophiolite, Oman. ISME J., 1. doi: 10.1038/s41396-019-0391-2 
Fones, E. M., Colman, D. R., Kraus, E. A., Stepanauskas, R., Templeton, A. S., Spear, J. R., \& Boyd, E. S. (2020). Diversification of methanogens into hyperalkaline serpentinizing environments through adaptations to minimize oxidant limitation. ISME J.. Retrieved from https://doi.org/10.1038/ s41396-020-00838-1 doi: 10.1038/s41396-020-00838-1

Fritz, P., Clark, I., Fontes, J.-C., Whiticar, M., \& Faber, E. (1992). Deuterium and ${ }^{13} \mathrm{C}$ evidence for low temperature production of hydrogen and methane in a highly alkaline groundwater environment in Oman. In International symposium on water-rock interaction (Vol. 1, pp. 793-796). AA Balkema Rotterdam.

Frost, B. R. (1985, Feb). On the Stability of Sulfides, Oxides, and Native Metals in Serpentinite. J. Petrol., 26(1), 31-63. doi: 10.1093/petrology/26.1.31

Giunta, T., Young, E. D., Warr, O., Kohl, I., Ash, J. L., Martini, A., ... Lollar, B. S. (2019). Methane sources and sinks in continental sedimentary systems: New insights from paired clumped isotopologues ${ }^{1} 3 \mathrm{CH}_{3} \mathrm{D}$ and ${ }^{1} 2 \mathrm{CH}_{2} \mathrm{D}^{2}$. Geochim. Cosmochim. Acta, 245, 327-351. Retrieved from http://www.sciencedirect.com/science/article/pii/S0016703718306161 doi: $10.1016 /$ j.gca.2018.10.030

Glein, C. R., Baross, J. A., \& Waite Jr, J. H. (2015). The pH of Enceladus' ocean. Geochim. Cosmochim. Acta, 162, 202-219. doi: 10.1016/j.gca.2015.04.017

Glein, C. R., \& Zolotov, M. Y. (2020, 02). Hydrogen, Hydrocarbons, and Habitability Across the Solar System. Elements, 16(1), 47-52. Retrieved from https:// doi.org/10.2138/gselements.16.1.47 doi: 10.2138/gselements.16.1.47

Glennie, K., Boeuf, M., Clarke, M. H., Moody-Stuart, M., Pilaar, W., \& Reinhardt, B. (1973). Late Cretaceous nappes in Oman Mountains and their geologic evolution. $\quad A A P G$ Bull., 57(1), 5-27. doi: 10.1306/819A4240-16C5-11D7 $-8645000102 \mathrm{C} 1865 \mathrm{D}$

Godard, M., Jousselin, D., \& Bodinier, J.-L. (2000). Relationships between geochemistry and structure beneath a palaeo-spreading centre: a study of the mantle section in the Oman ophiolite. Earth Planet. Sci. Lett., 180(1), 133 148. Retrieved from http://www.sciencedirect.com/science/article/pii/ S0012821X00001497 doi: 10.1016/S0012-821X(00)00149-7

Grozeva, N. G., Klein, F., Seewald, J. S., \& Sylva, S. P.

(2020, FEB 21). Chemical and isotopic analyses of hydrocarbon-bearing fluid inclusions in olivine-rich rocks [Article]. Philos. Trans. R. Soc., A, 378(2165, SI). doi: 10.1098/rsta.2018.0431

Gruen, D. S., Wang, D. T., Könneke, M., Top̧̧uoğlu, B. D., Stewart, L. C., Goldhammer, T., ... Ono, S. (2018). Experimental investigation on the controls of clumped isotopologue and hydrogen isotope ratios in microbial methane. Geochim. Cosmochim. Acta, 237, 339-356. Retrieved from http://www.sciencedirect.com/science/article/pii/S0016703718303442 doi: $10.1016 /$ j.gca.2018.06.029

Guilmette, C., Smit, M. A., van Hinsbergen, D. J. J., Gürer, D., Corfu, F., Charette, B.,... Savard, D. (2018). Forced subduction initiation recorded in the sole and crust of the Semail Ophiolite of Oman. Nat. Geosci., 11(9), 688695. Retrieved from https://doi.org/10.1038/s41561-018-0209-2 doi: 10.1038/s41561-018-0209-2

Hanghøj, K., Kelemen, P. B., Hassler, D., \& Godard, M. （2010, Jan). Composition and Genesis of Depleted Mantle Peridotites from the Wadi Tayin Massif, Oman Ophiolite; Major and Trace Element Geochemistry, and Os Isotope and PGE Systematics. J. Petrol., 51(1-2), 201-227. 10.1093/petrology/egp077

Hanson, R. S., \& Hanson, T. E. (1996). Methanotrophic bacteria. Microbiol. Mol. Biol. Rev., 60(2), 439-471. Retrieved from https://mmbr.asm.org/content/ $60 / 2 / 439$

Henry, E. A., Devereux, R., Maki, J. S., Gilmour, C. C., Woese, C. R., Man- 
delco, L., ... Mitchell, R. (1994). Characterization of a new thermophilic sulfate-reducing bacterium. Arch. Microbiol., 161(1), 62-69. Retrieved from https://doi.org/10.1007/BF00248894 doi: 10.1007/BF00248894

Hoehler, T. M. (2004). Biological energy requirements as quantitative boundary conditions for life in the subsurface. Geobiology, 2(4), 205-215. Retrieved from https://onlinelibrary.wiley.com/doi/abs/10.1111/ j.1472-4677.2004.00033.x doi: 10.1111/j.1472-4677.2004.00033.x

Horibe, Y., \& Craig, H. (1995). DH fractionation in the system methane-hydrogenwater. Geochim. Cosmochim. Acta, 59(24), 5209-5217. doi: 10.1016/0016 $-7037(95) 00391-6$

Hunt, J. M. (1996). Petroleum geochemistry and geology. New York: W.H. Freeman.

Jacquemin, M., Beuls, A., \& Ruiz, P. (2010). Catalytic production of methane from $\mathrm{CO}_{2}$ and $\mathrm{H}_{2}$ at low temperature: Insight on the reaction mechanism. Catal. Today, 157(1-4), 462-466. doi: 10.1016/j.cattod.2010.06.016

Johnson, J. W., Oelkers, E. H., \& Helgeson, H. C. ～(1992). SUPCRT92: A software package for calculating the standard molal thermodynamic properties of minerals, gases, aqueous species, and reactions from 1 to 5000 bar and 0 to $1000^{\circ} \mathrm{C}$. Comput. Geosci., 18(7), 899-947. Retrieved from https://www.sciencedirect.com/science/article/pii/009830049290029Q doi: 10.1016/0098-3004(92)90029-Q

Kampbell, D., Wilson, J., \& McInnes, D. (1998). DETERMINING DISSOLVED HYDROGEN, METHANE, AND VINYL CHLORIDE CONCENTRATIONS IN AQUEOUS SOLUTION ON A NANOMOLAR SCALE WITH THE BUBBLE STRIP METHOD. In Proceedings of the 1998 conference on hazardous waste research (p. 176-190).

Kelemen, P., Al Rajhi, A., Godard, M., Ildefonse, B., Köpke, J., MacLeod, C., ... Teagle, D. (2013). Scientific drilling and related research in the samail ophiolite, sultanate of Oman. Scientific Drilling 2013 (2013), Nr. 15, 2013(15), 6471. Retrieved from https://www.repo.uni-hannover.de/handle/123456789/ 1086

Kelemen, P., Matter, J., Teagle, D., Coggon, J., \& the Oman Drilling Project Science Team. (2020). Proceedings of the oman drilling project. In Proceedings of the oman drilling project (p. All pages.). College Station, TX. doi: 10.14379/OmanDP.proc.2020

Kelemen, P. B., \& Matter, J. (2008). In situ carbonation of peridotite for $\mathrm{CO}_{2}$ storage. Proc. Natl. Acad. Sci. U. S. A., 105(45), 17295-17300. doi: 10.1073/pnas .0805794105

Kelemen, P. B., Matter, J., Streit, E. E., Rudge, J. F., Curry, W. B., \& Blusztajn, J. (2011). Rates and mechanisms of mineral carbonation in peridotite: natural processes and recipes for enhanced, in situ $\mathrm{CO}_{2}$ capture and storage. Annu. Rev. Earth Planet. Sci., 39, 545-576. doi: 10.1146/ annurev-earth-092010-152509

Kelley, D. S. (1996). Methane-rich fluids in the oceanic crust. J. Geophys. Res.: Solid Earth, 101 (B2), 2943-2962. doi: 10.1029/95JB02252

Kelley, D. S., \& Früh-Green, G. L. (1999). Abiogenic methane in deep-seated midocean ridge environments: Insights from stable isotope analyses. J. Geophys. Res.: Solid Earth, 104(B5), 10439-10460. doi: 10.1029/1999JB900058

Kieft, T. L. (2016). Microbiology of the Deep Continental Biosphere. In Their world: A diversity of microbial environments (pp. 225-249). Cham: Springer International Publishing. Retrieved from https://doi.org/10.1007/978-3 -319-28071-4_6 doi: 10.1007/978-3-319-28071-4_6

Kieft, T. L., McCuddy, S. M., Onstott, T. C., Davidson, M., Lin, L.-H., Mislowack, B., .. van Heerden, A. (2005). Geochemically Generated, Energy-Rich Substrates and Indigenous Microorganisms in Deep, Ancient Groundwater. Geomicrobiol. J., 22(6), 325-335. Retrieved from https://doi.org/10.1080/ 
01490450500184876 doi: $10.1080 / 01490450500184876$

Klein, F., \& Bach, W. (2009, 02). Fe-Ni-Co-O-S Phase Relations in PeridotiteSeawater Interactions. J. Petrol., 50(1), 37-59. Retrieved from https://doi .org/10.1093/petrology/egn071 doi: 10.1093/petrology/egn071

Klein, F., Bach, W., Jöns, N., McCollom, T., Moskowitz, B., \& Berquó, T. (2009). Iron partitioning and hydrogen generation during serpentinization of abyssal peridotites from $15^{\circ} \mathrm{N}$ on the Mid-Atlantic Ridge. Geochim. Cosmochim. Acta, $73(22), 6868$ - 6893. Retrieved from http://www.sciencedirect.com/ science/article/pii/S0016703709005353 doi: 10.1016/j.gca.2009.08.021

Klein, F., Grozeva, N. G., \& Seewald, J. S. (2019). Abiotic methane synthesis and serpentinization in olivine-hosted fluid inclusions. Proc. Natl. Acad. Sci. U. S. A., 116(36), 17666-17672. Retrieved from https://www.pnas.org/content/ 116/36/17666 doi: 10.1073/pnas.1907871116

Knittel, K., \& Boetius, A. (2009). Anaerobic Oxidation of Methane: Progress with an Unknown Process. Annu. Rev. Microbiol., 63(1), 311-334. Retrieved from https://doi.org/10.1146/annurev.micro.61.080706.093130

(PMID: 19575572) doi: 10.1146/annurev.micro.61.080706.093130

Kopf, S., Davidheiser-Kroll, B., \& Kocken, I. (2021). Isoreader: An R package to read stable isotope data files for reproducible research. J. Open Source Software, 6(61), 2878. Retrieved from https://doi.org/10.21105/joss.02878 doi: $10.21105 /$ joss. 02878

Kral, T. A., Birch, W., Lavender, L. E., \& Virden, B. T. (2014). Potential use of highly insoluble carbonates as carbon sources by methanogens in the subsurface of Mars. $\quad$ Planet. Space Sci., 101, 181 - 185. Retrieved from http://www.sciencedirect.com/science/article/pii/S0032063314002049 doi: $10.1016 /$ j.pss.2014.07.008

Kraus, E. A., Nothaft, D., Stamps, B. W., Rempfert, K. R., Ellison, E. T., Matter, J. M., ... Spear, J. R. (2021). Molecular Evidence for an Active Microbial Methane Cycle in Subsurface Serpentinite-Hosted Groundwaters in the Samail Ophiolite, Oman. Appl. Environ. Microbiol., 87(2). Retrieved from https://aem.asm.org/content/87/2/e02068-20 doi: 10.1128/AEM.02068-20

Kumagai, H., Nakamura, K., Toki, T., Morishita, T., Okino, K., Ishibashi, J.-i., ... Takai, K. (2008, nov). Geological background of the Kairei and Edmond hydrothermal fields along the Central Indian Ridge : Implications for the distinct chemistry between their vent fluids. Geofluids, 8(4), 239251. Retrieved from https://ci.nii.ac.jp/naid/120006389526/en/ doi: 10.1111/j.1468-8123.2008.00223.x

Labidi, J., Young, E., Giunta, T., Kohl, I., Seewald, J., Tang, H., ... Früh-Green, G. (2020). Methane thermometry in deep-sea hydrothermal systems: Evidence for re-ordering of doubly-substituted isotopologues during fluid cooling. Geochim. Cosmochim. Acta, 288, 248-261. Retrieved from http://www.sciencedirect.com/science/article/pii/S0016703720305068 doi: $10.1016 /$ j.gca.2020.08.013

Lang, S. Q., Früh-Green, G. L., Bernasconi, S. M., Brazelton, W. J., Schrenk, M. O., \& McGonigle, J. M. (2018, Jan). Deeply-sourced formate fuels sulfate reducers but not methanogens at Lost City hydrothermal field. Sci. Rep., 8(1), 755. doi: $10.1038 / \mathrm{s} 41598-017-19002-5$

Laso-Pérez, R., Hahn, C., van Vliet, D. M., Tegetmeyer, H. E., Schubotz, F., Smit, N. T., ... Wegener, G. (2019). Anaerobic Degradation of Non-Methane Alkanes by "Candidatus Methanoliparia" in Hydrocarbon Seeps of the Gulf of Mexico. mBio, 10(4). Retrieved from https://mbio.asm.org/content/10/4/ e01814-19 doi: 10.1128/mBio.01814-19

Leong, J. A. M., \& Shock, E. L. (2020). Thermodynamic constraints on the geochemistry of low-temperature, continental, serpentinization-generated fluids. 
Am. J. Sci., 320(3), 185-235. doi: 10.2475/03.2020.01

Lippard, S., Shelton, A., \& Gass, I. (1986). The Ophiolite of Northern Oman (Vol. 11). Geological Society of London. mem. lyellcollection .org/content/11/1/39 Retrieved from https: // .1986.011.01.03

Lowell, R., Kolandaivelu, K., \& Rona, P. (2014). Hydrothermal Activity. In Reference module in earth systems and environmental sciences. Elsevier. Retrieved from http://www.sciencedirect.com/science/article/pii/ B9780124095489091326 doi: 10.1016/B978-0-12-409548-9.09132-6

Luesken, F. A., Wu, M. L., Op den Camp, H. J. M., Keltjens, J. T., Stunnenberg, H., Francoijs, K.-J., ... Jetten, M. S. M. (2012). Effect of oxygen on the anaerobic methanotroph 'Candidatus Methylomirabilis oxyfera': kinetic and transcriptional analysis. Environ. Microbiol., 14(4), 1024-1034. Retrieved from https://onlinelibrary.wiley.com/doi/abs/10.1111/ j.1462-2920.2011.02682.x doi: 10.1111/j.1462-2920.2011.02682.x

MacDougall, D., Crummett, W. B., et al. (1980). Guidelines for data acquisition and data quality evaluation in environmental chemistry. Anal. Chem., 52(14), $2242-2249$.

Marques, J., Etiope, G., Neves, M., Carreira, P., Rocha, C., Vance, S., ... Suzuki, S. (2018). Linking serpentinization, hyperalkaline mineral waters and abiotic methane production in continental peridotites: an integrated hydrogeological-bio-geochemical model from the Cabeço de Vide $\mathrm{CH}_{4}$-rich aquifer (Portugal). Appl. Geochem., 96, 287 - 301. Retrieved from http://www.sciencedirect.com/science/article/pii/S0883292718301987 doi: 10.1016/j.apgeochem.2018.07.011

Martini, A. M., Walter, L. M., Ku, T. C. W., Budai, J. M., McIntosh, J. C., \& Schoell, M. $\quad(2003,08) . \quad$ Microbial production and modification of gases in sedimentary basins: A geochemical case study from a Devonian shale gas play, Michigan basin. $\quad A A P G$ Bull., 87(8), 1355-1375. Retrieved from https://doi.org/10.1306/031903200184 doi: 10.1306/031903200184

Matter, J. M., Pezard, P. A., Henry, G., Brun, L., Célérier, B., Lods, G., ... Al Qassabi, A. (2017, December). Oman Drilling Project Phase I Borehole Geophysical Survey. AGU Fall Meeting Abstracts.

Matter, J. M., Waber, H., Loew, S., \& Matter, A. (2006). Recharge areas and geochemical evolution of groundwater in an alluvial aquifer system in the Sultanate of Oman. Hydrogeol. J., 14 (1-2), 203-224. doi: 10.1007/s10040-004-0425-2

McCollom, T. M. (1999). Methanogenesis as a potential source of chemical energy for primary biomass production by autotrophic organisms in hydrothermal systems on Europa. Journal of Geophysical Research: Planets, 104(E12), 30729-30742. doi: 10.1029/1999JE001126

McCollom, T. M. (2016). Abiotic methane formation during experimental serpentinization of olivine. Proc. Natl. Acad. Sci. U. S. A., 113(49), 13965-13970. doi: $10.1073 /$ pnas. 1611843113

McCollom, T. M., \& Bach, W. (2009). Thermodynamic constraints on hydrogen generation during serpentinization of ultramafic rocks. Geochim. Cosmochim. Acta, 73(3), 856-875. doi: 10.1016/j.gca.2008.10.032

McCollom, T. M., \& Seewald, J. S. (2003). Experimental constraints on the hydrothermal reactivity of organic acids and acid anions: I. Formic acid and formate. Geochim. Cosmochim. Acta, 67(19), 3625 - 3644. Retrieved from http://www.sciencedirect.com/science/article/pii/S0016703703001364 doi: 10.1016/S0016-7037(03)00136-4

McDermott, J. M., Seewald, J. S., German, C. R., \& Sylva, S. P. (2015). Pathways for abiotic organic synthesis at submarine hydrothermal fields. Proc. Natl. Acad. Sci. U. S. A., 112(25), 7668-7672. doi: 10.1073/pnas.1506295112 
McKay, C. P., Porco, C. C., Altheide, T., Davis, W. L., \& Kral, T. A.

(2008). The Possible Origin and Persistence of Life on Enceladus and Detection of Biomarkers in the Plume. Astrobiology, 8(5), 909-919. Retrieved from https://doi.org/10.1089/ast.2008.0265 (PMID: 18950287) doi: 10.1089 /ast.2008.0265

Ménez, B. (2020, 02). Abiotic Hydrogen and Methane: Fuels for Life. Elements, 16(1), 39-46. Retrieved from https://doi.org/10.2138/gselements.16.1 .39 doi: $10.2138 /$ gselements.16.1.39

Merlivat, L., Pineau, F., \& Javoy, M. (1987). Hydrothermal vent waters at $13^{\circ} \mathrm{N}$ on the East Pacific Rise: isotopic composition and gas concentration. Earth Planet. Sci. Lett., 84(1), 100 - 108. Retrieved from http:// www.sciencedirect.com/science/article/pii/0012821X87901804 doi: 10.1016/0012-821X(87)90180-4

Mervine, E. M., Humphris, S. E., Sims, K. W., Kelemen, P. B., \& Jenkins, W. J. (2014). Carbonation rates of peridotite in the Samail Ophiolite, Sultanate of Oman, constrained through ${ }^{14} \mathrm{C}$ dating and stable isotopes. Geochim. Cosmochim. Acta, 126, 371-397. Retrieved from http://www.sciencedirect.com/science/article/pii/S0016703713006467 doi: $10.1016 /$ j.gca.2013.11.007

Michaelis, W., Seifert, R., Nauhaus, K., Treude, T., Thiel, V., Blumenberg, M., ... Gulin, M. B. (2002). Microbial Reefs in the Black Sea Fueled by Anaerobic Oxidation of Methane. Science, 297(5583), 1013-1015. Retrieved from https://science.sciencemag.org/content/297/5583/1013 doi: 10.1126/science.1072502

Milkov, A. V., \& Etiope, G. (2018). Revised genetic diagrams for natural gases based on a global dataset of ¿20,000 samples. Org. Geochem., 125, 109-120. doi: 10.1016/j.orggeochem.2018.09.002

Miller, H. M., Chaudhry, N., Conrad, M. E., Bill, M., Kopf, S. H., \& Templeton, A. S. (2018). Large carbon isotope variability during methanogenesis under alkaline conditions. Geochim. Cosmochim. Acta, 237, 18 - 31. Retrieved from http://www.sciencedirect.com/science/article/pii/S0016703718303223 doi: 10.1016/j.gca.2018.06.007

Miller, H. M., Matter, J. M., Kelemen, P., Ellison, E. T., Conrad, M., Fierer, N., ... Templeton, A. S. (2017). Reply to "Methane origin in the Samail ophiolite: Comment on 'Modern water/rock reactions in Oman hyperalkaline peridotite aquifers and implications for microbial habitability"' [Geochim. Cosmochim. Acta 179 (2016) 217-241]. Geochim. Cosmochim. Acta, 197, 471 473. Retrieved from http://www.sciencedirect.com/science/article/pii/ S0016703716306482 doi: 10.1016/j.gca.2016.11.011

Miller, H. M., Matter, J. M., Kelemen, P., Ellison, E. T., Conrad, M. E., Fierer, N., ... Templeton, A. S. (2016). Modern water/rock reactions in Oman hyperalkaline peridotite aquifers and implications for microbial habitability. Geochim. Cosmochim. Acta, 179, 217 - 241. Retrieved from http://www.sciencedirect.com/science/article/pii/S0016703716300205 doi: 10.1016/j.gca.2016.01.033

Miller, H. M., Mayhew, L. E., Ellison, E. T., Kelemen, P., Kubo, M., \& Templeton, A. S. (2017). Low temperature hydrogen production during experimental hydration of partially-serpentinized dunite. Geochim. Cosmochim. Acta, 209, 161 - 183. Retrieved from http://www.sciencedirect.com/science/article/ pii/S0016703717302454 doi: 10.1016/j.gca.2017.04.022

Miura, M., Arai, S., \& Mizukami, T. (2011). Raman spectroscopy of hydrous inclusions in olivine and orthopyroxene in ophiolitic harzburgite: Implications for elementary processes in serpentinization. J. Mineral. Petrol. Sci., advpub, 1103030170-1103030170. doi: 10.2465/jmps.101021d

Moser, D. P., Gihring, T. M., Brockman, F. J., Fredrickson, J. K., Balkwill, 
D. L., Dollhopf, M. E., ... Onstott, T. C. (2005). Desulfotomaculum and Methanobacterium spp. Dominate a 4- to 5-Kilometer-Deep Fault. Appl. Environ. Microbiol., 71(12), 8773-8783. Retrieved from https://aem.asm.org/ content/71/12/8773 doi: 10.1128/AEM.71.12.8773-8783.2005

Murad, A. A., \& Krishnamurthy, R. (2004). Factors controlling groundwater quality in Eastern United Arab Emirates: a chemical and isotopic approach. J. Hydro., 286(1), 227 - 235. Retrieved from http:// www.sciencedirect.com/science/article/pii/S0022169403003949 doi 10.1016/j.jhydrol.2003.09.020

Neal, C., \& Stanger, G. (1983). Hydrogen generation from mantle source rocks in Oman. Earth Planet. Sci. Lett., 66, 315 - 320. Retrieved from http:// www.sciencedirect.com/science/article/pii/0012821X83901449 doi: 10 .1016/0012-821X(83)90144-9

Neal, C., \& Stanger, G. (1985). Past and present serpentinisation of ultramafic rocks; an example from the Semail Ophiolite Nappe of Northern Oman. In The chemistry of weathering (pp. 249-275). Springer. doi: 10.1007/978-94-009-5333 $-8 \_15$

Nicolas, A. (1989). Structures of Ophiolites and Dynamics of Oceanic Lithosphere SpringerLink. Springer, Dordrecht. doi: 10.1007/978-94-009-2374-4

Nicolas, A., Boudier, F., Ildefonse, B., \& Ball, E. (2000). Accretion of Oman and United Arab Emirates ophiolite-discussion of a new structural map. Marine Geophysical Researches, 21(3-4), 147-180. doi: 10.1023/A:1026769727917

Noël, J., Godard, M., Oliot, E., Martinez, I., Williams, M., Boudier, F., ... Gouze, P. (2018). Evidence of polygenetic carbon trapping in the Oman Ophiolite: Petro-structural, geochemical, and carbon and oxygen isotope study of the Wadi Dima harzburgite-hosted carbonates (Wadi Tayin massif, Sultanate of Oman). Lithos, 323, 218 - 237. Retrieved from http://www.sciencedirect.com/science/article/pii/S0024493718302998 (ABYSS) doi: 10.1016/j.lithos.2018.08.020

Nolan, S. C., Skelton, P. W., Clissold, B. P., \& Smewing, J. D. (1990). Maastrichtian to early Tertiary stratigraphy and palaeogeography of the Central and Northern Oman Mountains. Geological Society, London, Special Publications, 49(1), 495-519. Retrieved from https://sp.lyellcollection.org/ content/49/1/495 doi: 10.1144/GSL.SP.1992.049.01.31

Nothaft, D., Templeton, A. S., Boyd, E., Matter, J., Stute, M., \& Paukert Vankeuren, A. N. (2021). Aqueous geochemical and microbial variation across discrete depth intervals in a peridotite aquifer assessed using a packer system in the samail ophiolite, oman. Earth and Space Science Open Archive, 34. Retrieved from https://doi.org/10.1002/essoar.10506402.2 doi: 10.1002/essoar.10506402.2

Nothaft, D. B. (2019a, May). Bubble strip aqueous gas sampling. Retrieved 202105-17, from https://www.protocols.io/view/bubble-strip-aqueous-gas -sampling-2x5gfq6 doi: 10.17504/protocols.io.2x5gfq6

Nothaft, D. B. (2019b). Dissolved inorganic carbon concentration and ${ }^{13} \mathrm{C} /{ }^{12} \mathrm{C}$. Retrieved 2021-05-17, from https://www.protocols.io/view/ dissolved-inorganic-carbon-concentration-and-13c-1-zduf 26w doi: 10.17504/protocols.io.zduf26w

Nothaft, D. B., Rempfert, K. R., \& Kraus, E. A. (2021, May). danote/Samail_16S_compilation: First release of Samail 16S data processing repository. Zenodo. Retrieved from https://doi.org/10.5281/zenodo. 4768396 doi: $10.5281 /$ zenodo.4768396

Nothaft, D. B., Templeton, A. S., Rhim, J. H., Wang, D. T., Labidi, J., Miller, H. M., ... Team, T. O. D. P. S. (2021, May). danote/Oman_CH4_stable_isotopes: First release of Oman_CH4_stable_isotopes. Zenodo. Retrieved from https://doi.org/10.5281/zenodo.4768548 doi: 
10.5281/zenodo.4768548

Ono, S., Wang, D. T., Gruen, D. S., Sherwood Lollar, B., Zahniser, M. S., McManus, B. J., \& Nelson, D. D. (2014). Measurement of a Doubly Substituted Methane Isotopologue, ${ }^{13} \mathrm{CH}_{3} \mathrm{D}$, by Tunable Infrared Laser Direct Absorption Spectroscopy. Anal. Chem., 86(13), 6487-6494. Retrieved from https://doi.org/10.1021/ac5010579 (PMID: 24895840) doi: $10.1021 /$ ac5010579

Parkhurst, D. L., \& Appelo, C. A. J. (2013). Description of input and examples for PHREEQC version 3-A computer program for speciation, batch-reaction, one-dimensional transport, and inverse geochemical calculations (6th ed.) [Computer software manual].

Parsons International \& Co., L. $\quad$ (2005, December). Report on Findings of Exploration Program of Deep Groundwater in Northern Sharqiyah (Tech. Rep.). PO Box 162, Postal Code 117, Wadi Al Kabir, Sultanate of Oman: Ministry of Regional Municipalities, Environment and Water Resources.

Paukert, A. (2014). Mineral Carbonation in Mantle Peridotite of the Samail Ophiolite, Oman: Implications for permanent geological carbon dioxide capture and storage (Doctoral dissertation, Columbia University). doi: 10.7916/D85M63WZ

Paukert, A. N., Matter, J. M., Kelemen, P. B., Shock, E. L., \& Havig, J. R. (2012). Reaction path modeling of enhanced in situ $\mathrm{CO}_{2}$ mineralization for carbon sequestration in the peridotite of the Samail Ophiolite, Sultanate of Oman. Chem. Geol., 330, 86-100. doi: 10.1016/j.chemgeo.2012.08.013

Paukert Vankeuren, A. N., Matter, J. M., Stute, M., \& Kelemen, P. B. Multitracer determination of apparent groundwater ages in peridotite aquifers within the Samail ophiolite, Sultanate of Oman. Earth Planet. Sci. Lett., 516, 37-48. doi: 10.1016/j.epsl.2019.03.007

Peters, J. W., Schut, G. J., Boyd, E. S., Mulder, D. W., Shepard, E. M., Broderick, J. B., ... Adams, M. W. (2015). [FeFe]- and [NiFe]-hydrogenase diversity, mechanism, and maturation. Biochim. Biophys. Acta, Mol. Cell Res., 1853(6), 1350 - $1369 . \quad$ Retrieved from http://www.sciencedirect.com/ science/article/pii/S0167488914004194 (SI: Fe/S proteins) doi: 10.1016/j.bbamcr.2014.11.021

Proskurowski, G., Lilley, M. D., Seewald, J. S., Früh-Green, G. L., Olson, E. J., Lupton, J. E., ... Kelley, D. S. (2008). Abiogenic hydrocarbon production at Lost City hydrothermal field. Science, 319(5863), 604-607. doi: 10.1126/science.1151194

Quast, C., Pruesse, E., Gerken, J., Peplies, J., Yarza, P., Yilmaz, P., ... Glöckner, F. O. (2012, Nov). The SILVA ribosomal RNA gene database project: improved data processing and web-based tools. Nucleic Acids Res., 41(D1), D590-D596. doi: 10.1093/nar/gks1219

R Core Team. (2019). R: A Language and Environment for Statistical Computing. Vienna, Austria. Retrieved from https://www.R-project.org/

Rabu, D., Nehlig, P., \& Roger, J. (1993). Stratigraphy and structure of the Oman Mountains. Documents- B. R. G. M..

Rempfert, K. R., Miller, H. M., Bompard, N., Nothaft, D., Matter, J. M., Kelemen, P., ... Templeton, A. S. (2017, February). Geological and geochemical controls on subsurface microbial life in the Samail Ophiolite, Oman. Front. Microb., 8(56), 1-21. doi: 10.3389/fmicb.2017.00056

Rioux, M., Garber, J., Bauer, A., Bowring, S., Searle, M., Kelemen, P., \& Hacker, B. (2016). Synchronous formation of the metamorphic sole and igneous crust of the Semail ophiolite: New constraints on the tectonic evolution during ophiolite formation from high-precision U-Pb zircon geochronology. Earth Planet. Sci. Lett., 451, 185 - 195. Retrieved from http://www. sciencedirect.com/ science/article/pii/S0012821X16303387 doi: 10.1016/j.epsl.2016.06.051 
Rollinson, H. (2005). Chromite in the mantle section of the Oman ophiolite: A new genetic model. Island Arc, 14(4), 542-550. Retrieved from https:// onlinelibrary.wiley.com/doi/abs/10.1111/j.1440-1738.2005.00482.x doi: $10.1111 / \mathrm{j} .1440-1738.2005 .00482 . x$

Rooney, M. A., Claypool, G. E., \& Moses Chung, H. (1995). Modeling thermogenic gas generation using carbon isotope ratios of natural gas hydrocarbons. Chem. Geol., 126(3), 219-232. Retrieved from https://www.sciencedirect.com/ science/article/pii/0009254195001190 (Processes of Natural Gas Formation) doi: 10.1016/0009-2541(95)00119-0

Sachan, H. K., Mukherjee, B. K., \& Bodnar, R. J. (2007). Preservation of methane generated during serpentinization of upper mantle rocks: Evidence from fluid inclusions in the Nidar ophiolite, Indus Suture Zone, Ladakh (India). $\quad$ Earth Planet. Sci. Lett., 257(1), 47 - $59 . \quad$ Retrieved from http://www.sciencedirect.com/science/article/pii/S0012821X07000969 doi: $10.1016 /$ j.epsl.2007.02.023

Sander, R. (2015). Compilation of Henry's law constants (version 4.0) for water as solvent. Atmos. Chem. Phys., 15(8). doi: 10.5194/ACP-15-4399-2015

Schidlowski, M. (2001). Carbon isotopes as biogeochemical recorders of life over 3.8 Ga of Earth history: evolution of a concept. Precambrian Res., 106(1), 117 134. Retrieved from http://www.sciencedirect.com/science/article/pii/ S0301926800001285 doi: 10.1016/S0301-9268(00)00128-5

Schink, B. (1997). Energetics of syntrophic cooperation in methanogenic degradation. Microbiol. Mol. Biol. Rev., 61(2), 262-280. Retrieved from https://mmbr . asm.org/content/61/2/262

Schink, B., \& Stams, A. J. M. (2006). Syntrophism among Prokaryotes [Article; Book Chapter]. In Dworkin, $\mathrm{M}$ and Falkow, S and Rosenberg, E and Schleifer, KH and Stackebrandt, E (Ed.), PROKARYOTES: A HANDBOOK ON THE BIOLOGY OF BACTERIA, VOL 2, THIRD EDITION: ECOPHYSIOLOGY AND BIOCHEMISTRY (p. 309-335). 233 SPRING STREET, NEW YORK, NY 10013, UNITED STATES: SPRINGER. doi: $\left\{10.1007 / 0-387-30742-7 \backslash \_11\right\}$

Sekiguchi, Y., Muramatsu, M., Imachi, H., Narihiro, T., Ohashi, A., Harada, H., ... Kamagata, Y. (2008). Thermodesulfovibrio aggregans sp. nov. and Thermodesulfovibrio thiophilus sp. nov., anaerobic, thermophilic, sulfate-reducing bacteria isolated from thermophilic methanogenic sludge, and emended description of the genus Thermodesulfovibrio [Journal Article]. Int. J. Syst. Evol. Microbiol., 58(11), 2541-2548. Retrieved from https://www.microbiologyresearch.org/content/journal/ijsem/ 10.1099/ijs.0.2008/000893-0 doi: 10.1099/ijs.0.2008/000893-0

Shennan, J. L. (2006). Utilisation of $\mathrm{C} 2-\mathrm{C} 4$ gaseous hydrocarbons and isoprene by microorganisms. J. Appl. Chem. Biotechnol., 81(3), 237-256. Retrieved from https://onlinelibrary.wiley.com/doi/abs/10.1002/jctb.1388 doi: 10 $.1002 /$ jctb. 1388

Sherwood Lollar, B., Lacrampe-Couloume, G., Voglesonger, K., Onstott, T., Pratt, L., \& Slater, G. (2008). Isotopic signatures of $\mathrm{CH}_{4}$ and higher hydrocarbon gases from Precambrian Shield sites: A model for abiogenic polymerization of hydrocarbons. Geochim. Cosmochim. Acta, 72(19), 4778 - 4795. Retrieved from http://www.sciencedirect.com/science/article/pii/ S0016703708004250 doi: 10.1016/j.gca.2008.07.004

Sherwood Lollar, B., Westgate, T. D., Ward, J. A., Slater, G. F., \& LacrampeCouloume, G. (2002, Apr). Abiogenic formation of alkanes in the Earth's crust as a minor source for global hydrocarbon reservoirs. Nature, 416(6880), 522-524. doi: $10.1038 / 416522$ a

Shock, E. L. (1992). Chemical Environments of Submarine Hydrothermal Systems. In Marine Hydrothermal Systems and the Origin of Life (pp. 67-107). 
Springer, Dordrecht. doi: 10.1007/978-94-011-2741-7_5

Singh, R., Guzman, M. S., \& Bose, A. (2017). Anaerobic Oxidation of Ethane, Propane, and Butane by Marine Microbes: A Mini Review. Front. Microb., 8, 2056. Retrieved from https://www.frontiersin.org/article/10.3389/ fmicb.2017.02056 doi: 10.3389/fmicb.2017.02056

Skelton, P. W., Nolan, S. C., \& Scott, R. W. (1990). The Maastrichtian transgression onto the northwestern flank of the Proto-Oman Mountains: sequences of rudist-bearing beach to open shelf facies. Geological Society, London, Special Publications, 49(1), 521-547. Retrieved from https://sp.lyellcollection . org/content/49/1/521 doi: 10.1144/GSL.SP.1992.049.01.32

Soret, M., Bonnet, G., Larson, K., Agard, P., Cottle, J., Dubacq, B., \& Button, M. (2020, January). Slow subduction initiation forces fast ophiolite formation Soret. In International conference on ophiolites and the oceanic lithosphere: Results of the oman drilling project and related research (p. 232).

Stanger, G. (1986). The hydrogeology of the Oman Mountains (Doctoral dissertation, Open University). doi: 10.21954/ou.ro.0000deb3

Stolper, D., Martini, A., Clog, M., Douglas, P., Shusta, S., Valentine, D., ... Eiler, J. (2015). Distinguishing and understanding thermogenic and biogenic sources of methane using multiply substituted isotopologues. Geochim. Cosmochim. Acta, 161, 219 - 247. Retrieved from http://www.sciencedirect.com/ science/article/pii/S0016703715002082 doi: 10.1016/j.gca.2015.04.015

Stolper, D. A., Lawson, M., Formolo, M. J., Davis, C. L., Douglas, P. M. J., \& Eiler, J. M. (2018). The utility of methane clumped isotopes to constrain the origins of methane in natural gas accumulations. Geological Society, London, Special Publications, 468(1), 23-52. Retrieved from https:// sp.lyellcollection.org/content/468/1/23 doi: 10.1144/SP468.3

Streit, E., Kelemen, P., \& Eiler, J. (2012, Nov 01). Coexisting serpentine and quartz from carbonate-bearing serpentinized peridotite in the Samail Ophiolite, Oman. Contrib. Mineral. Petrol., 164(5), 821-837. Retrieved from https:// doi.org/10.1007/s00410-012-0775-z doi: 10.1007/s00410-012-0775-z

Suzuki, S., Kuenen, J. G., Schipper, K., van der Velde, S., Ishii, S., Wu, A., ... Nealson, K. H. (2014, May). Physiological and genomic features of highly alkaliphilic hydrogen-utilizing Betaproteobacteria from a continental serpentinizing site. Nat. Commun., 5, 3900. doi: 10.1038/ncomms4900

Terken, J. M. J. (1999, Apr). The Natih Petroleum System of North Oman. GeoArabia, 4(2), 157-180. Retrieved from https://pubs.geoscienceworld.org/ geoarabia/article/4/2/157/566618

Terzer, S., Wassenaar, L. I., Araguás-Araguás, L. J., \& Aggarwal, P. K. (2013). Global isoscapes for $\delta^{18} \mathrm{O}$ and $\delta^{2} \mathrm{H}$ in precipitation: improved prediction using regionalized climatic regression models. Hydrol. Earth Syst. Sci., 17(11), 47134728. Retrieved from https://www.hydrol-earth-syst-sci.net/17/4713/ 2013/ doi: 10.5194/hess-17-4713-2013

Thampi, K. R., Kiwi, J., \& Graetzel, M. (1987). Methanation and photomethanation of carbon dioxide at room temperature and atmospheric pressure. Nature, 327(6122), 506.

Timmers, P. H., Welte, C. U., Koehorst, J. J., Plugge, C. M., Jetten, M. S., \& Stams, A. J. (2017). Reverse methanogenesis and respiration in methanotrophic archaea. Archaea, 2017. doi: 10.1155/2017/1654237

USGS. (2010). Digital Elevation - Global Multi-resolution Terrain Elevation Data 2010 (GMTED2010). doi: /10.5066/F7J38R2N

Vacquand, C., Deville, E., Beaumont, V., Guyot, F., Sissmann, O., Pillot, D., ... Prinzhofer, A. (2018). Reduced gas seepages in ophiolitic complexes: evidences for multiple origins of the $\mathrm{H}_{2}-\mathrm{CH}_{4}-\mathrm{N}_{2}$ gas mixtures. Geochim. Cosmochim. Acta, 223, 437-461. doi: 10.1016/j.gca.2017.12.018

Waite, J. H., Glein, C. R., Perryman, R. S., Teolis, B. D., Magee, B. A., Miller, G., 
... Bolton, S. J. (2017). Cassini finds molecular hydrogen in the Enceladus plume: Evidence for hydrothermal processes. Science, 356(6334), 155-159. Retrieved from https://science.sciencemag.org/content/356/6334/155 doi: 10.1126/science.aai8703

Wang, D. T., Gruen, D. S., Lollar, B. S., Hinrichs, K.-U., Stewart, L. C., Holden, J. F., ... others (2015). Nonequilibrium clumped isotope signals in microbial methane. Science, 348 (6233), 428-431. doi: 10.1126/science.aaa4326

Wang, D. T., Reeves, E. P., McDermott, J. M., Seewald, J. S., \& Ono, S. Clumped isotopologue constraints on the origin of methane at seafloor hot springs. Geochim. Cosmochim. Acta, 223, 141-158. doi: 10.1016/ j.gca.2017.11.030

Wang, D. T., Welander, P. V., \& Ono, S. (2016). Fractionation of the methane isotopologues ${ }^{13} \mathrm{CH}_{4},{ }^{12} \mathrm{CH}_{3} \mathrm{D}$, and ${ }^{13} \mathrm{CH}_{3} \mathrm{D}$ during aerobic oxidation of methane by Methylococcus capsulatus (Bath). Geochim. Cosmochim. Acta, 192, 186202. doi: $10.1016 /$ j.gca.2016.07.031

Wang, Q., Garrity, G. M., Tiedje, J. M., \& Cole, J. R. (2007). Naïve Bayesian Classifier for Rapid Assignment of rRNA Sequences into the New Bacterial Taxonomy. Appl. Environ. Microbiol., 73(16), 5261-5267. Retrieved from https://aem.asm.org/content/73/16/5261 doi: 10.1128/AEM.00062-07

Weinstein, M. (2019). Zymo-Research/figaro. Zymo Research. Retrieved 2021-0517, from https://github.com/Zymo-Research/figaro (original-date: 201904-11T21:27:26Z)

Welhan, J. A., \& Craig, H. (1983). Methane, Hydrogen and Helium in Hydrothermal Fluids at $21^{\circ} \mathrm{N}$ on the East Pacific Rise. In Hydrothermal processes at seafloor spreading centers (pp. 391-409). Boston, MA: Springer US. Retrieved from https://doi.org/10.1007/978-1-4899-0402-7_17 doi: 10.1007/978-1-4899 $-0402-7 \_17$

Welte, C. U., Rasigraf, O., Vaksmaa, A., Versantvoort, W., Arshad, A., Op den Camp, H. J., ... Reimann, J. (2016). Nitrate- and nitrite-dependent anaerobic oxidation of methane. Environ. Microbiol. Rep., 8(6), 941-955. Retrieved from https://onlinelibrary.wiley.com/doi/abs/10.1111/1758-2229.12487 doi: 10.1111/1758-2229.12487

Weyhenmeyer, C. E., Burns, S. J., Waber, H. N., Macumber, P. G., \& Matter, A. (2002). Isotope study of moisture sources, recharge areas, and groundwater flow paths within the eastern Batinah coastal plain, Sultanate of Oman. Water Resources Research, 38(10). doi: 10.1029/2000WR000149

Whiticar, M. J. (1999). Carbon and hydrogen isotope systematics of bacterial formation and oxidation of methane. Chem. Geol., 161(1), 291 - 314. Retrieved from http://www.sciencedirect.com/science/article/pii/S0009254199000923 doi: 10.1016/S0009-2541(99)00092-3

Wu, Y. (2017, January). yhwu/idemp. Retrieved 2021-05-17, from https://github .com/yhwu/idemp (original-date: 2014-11-24T02:52:59Z)

Young, E., Kohl, I., Lollar, B. S., Etiope, G., Rumble Iii, D., Li, S., ... others (2017). The relative abundances of resolved ${ }^{12} \mathrm{CH}_{2} \mathrm{D}_{2}$ and ${ }^{13} \mathrm{CH}_{3} \mathrm{D}$ and mechanisms controlling isotopic bond ordering in abiotic and biotic methane gases. Geochim. Cosmochim. Acta, 203, 235-264. doi: 10.1016/j.gca.2016.12.041

Young, E. D. (2020). A Two-Dimensional Perspective on $\mathrm{CH}_{4}$ Isotope Clumping : Distinguishing Process from Source. In Deep carbon : Past to present (p. 388414). Cambridge University Press. Retrieved from https://www . cambridge .org/us/academic/subjects/earth-and-environmental-science/ geochemistry-and-environmental-chemistry/deep-carbon-past-present ?format=HB\&isbn=9781108477499\#resources doi: 10.1017/9781108677950

Young, E. D., Rumble, D., Freedman, P., \& Mills, M. (2016). A large-radius highmass-resolution multiple-collector isotope ratio mass spectrometer for analysis of rare isotopologues of $\mathrm{O}_{2}, \mathrm{~N}_{2}, \mathrm{CH}_{4}$ and other gases. Int. J. Mass Spectrom., 
401, 1 - 10. Retrieved from http://www.sciencedirect.com/science/ article/pii/S138738061600035X doi: 10.1016/j.ijms.2016.01.006

Zimmer, K., Zhang, Y., Lu, P., Chen, Y., Zhang, G., Dalkilic, M., \& Zhu, C. (2016). SUPCRTBL: A revised and extended thermodynamic dataset and software package of SUPCRT92. Comput. Geosci., 90, 97-111. Retrieved from https:// www.sciencedirect.com/science/article/pii/S0098300416300371 doi: 10.1016/j.cageo.2016.02.013

Zwicker, J., Birgel, D., Bach, W., Richoz, S., Smrzka, D., Grasemann, B., .. others (2018). Evidence for archaeal methanogenesis within veins at the onshore serpentinite-hosted Chimaera seeps, Turkey. Chem. Geol., 483, 567-580. doi: 10.1016/j.chemgeo.2018.03.027 
Figure 1. 


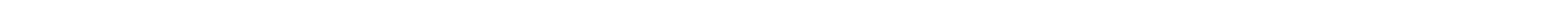


Figure 2. 


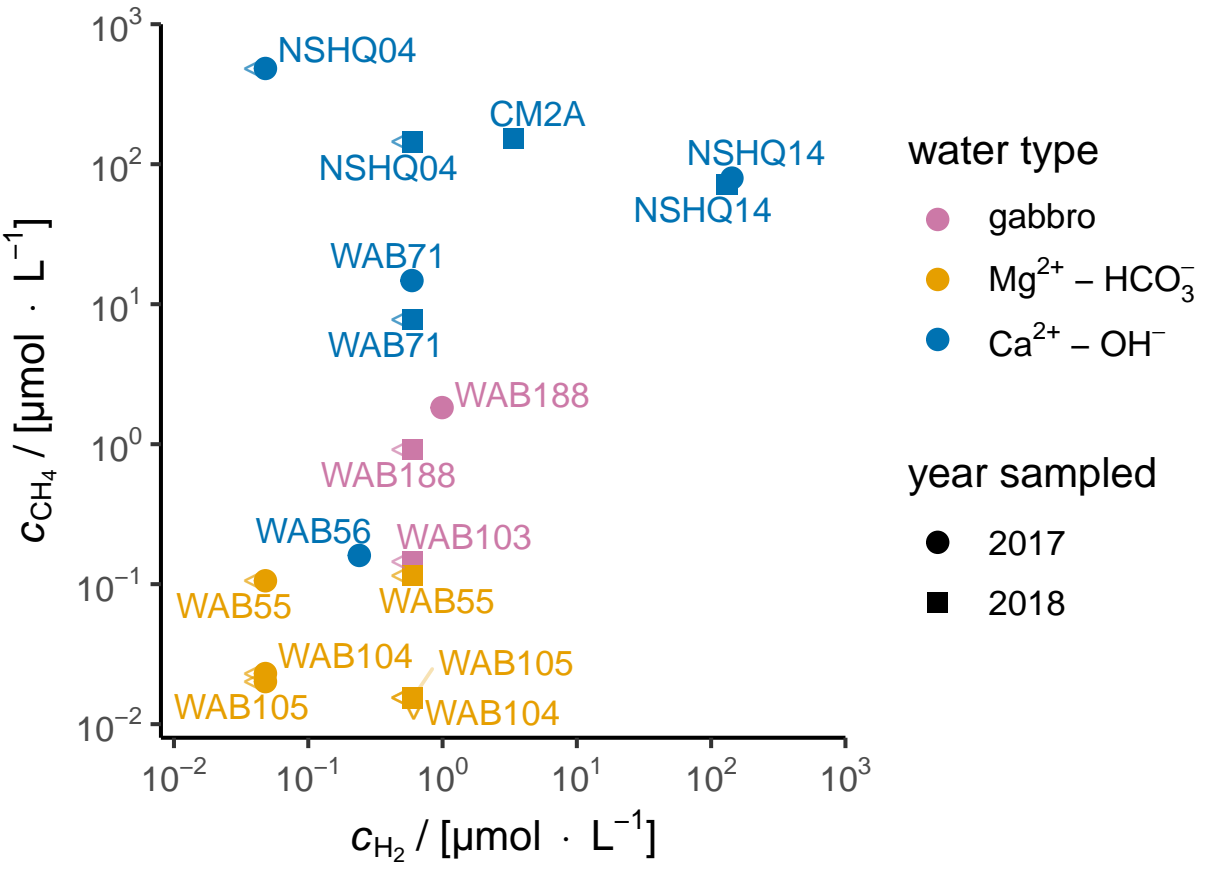


Figure 3. 
Figure 4. 


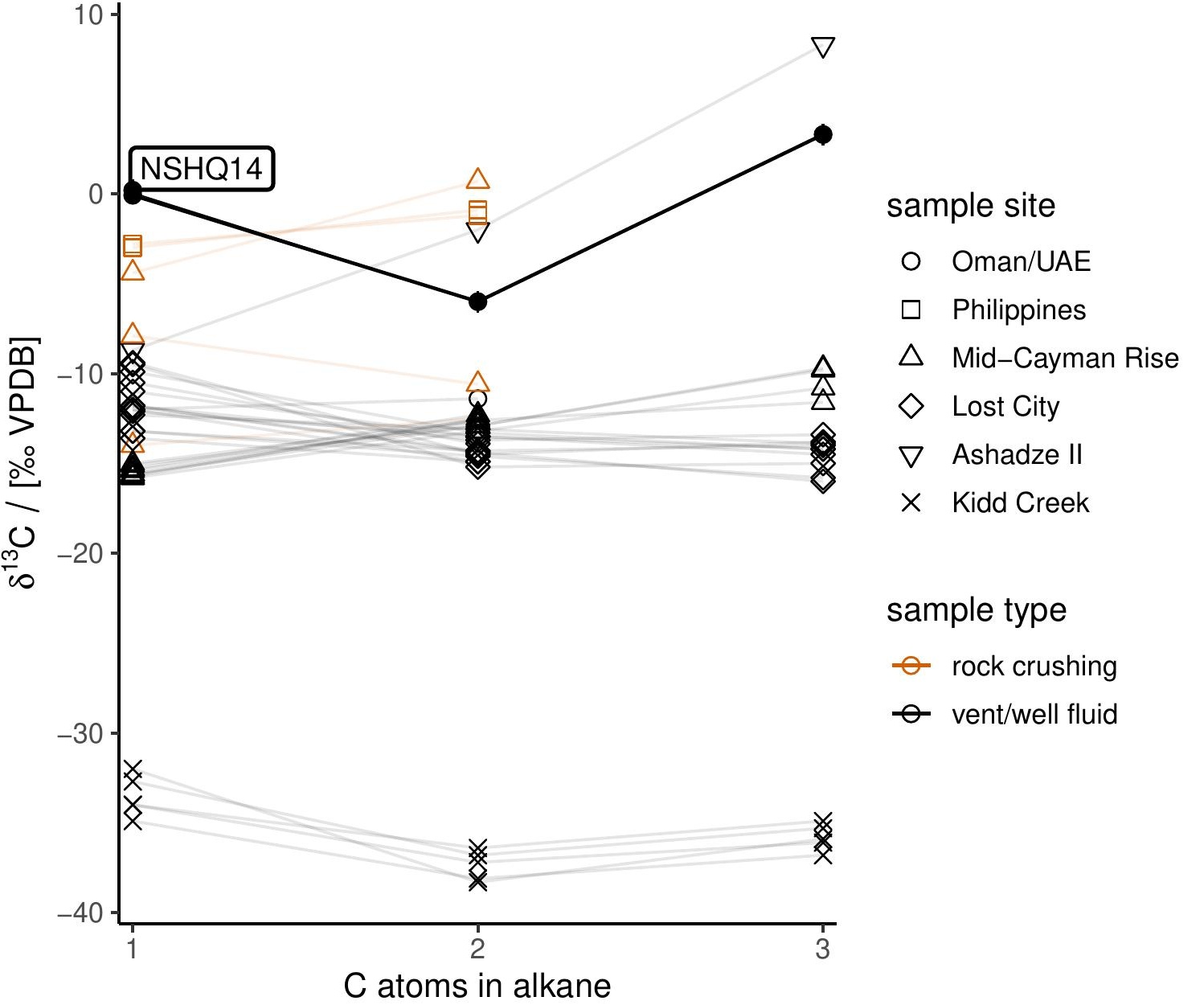


Figure 5. 


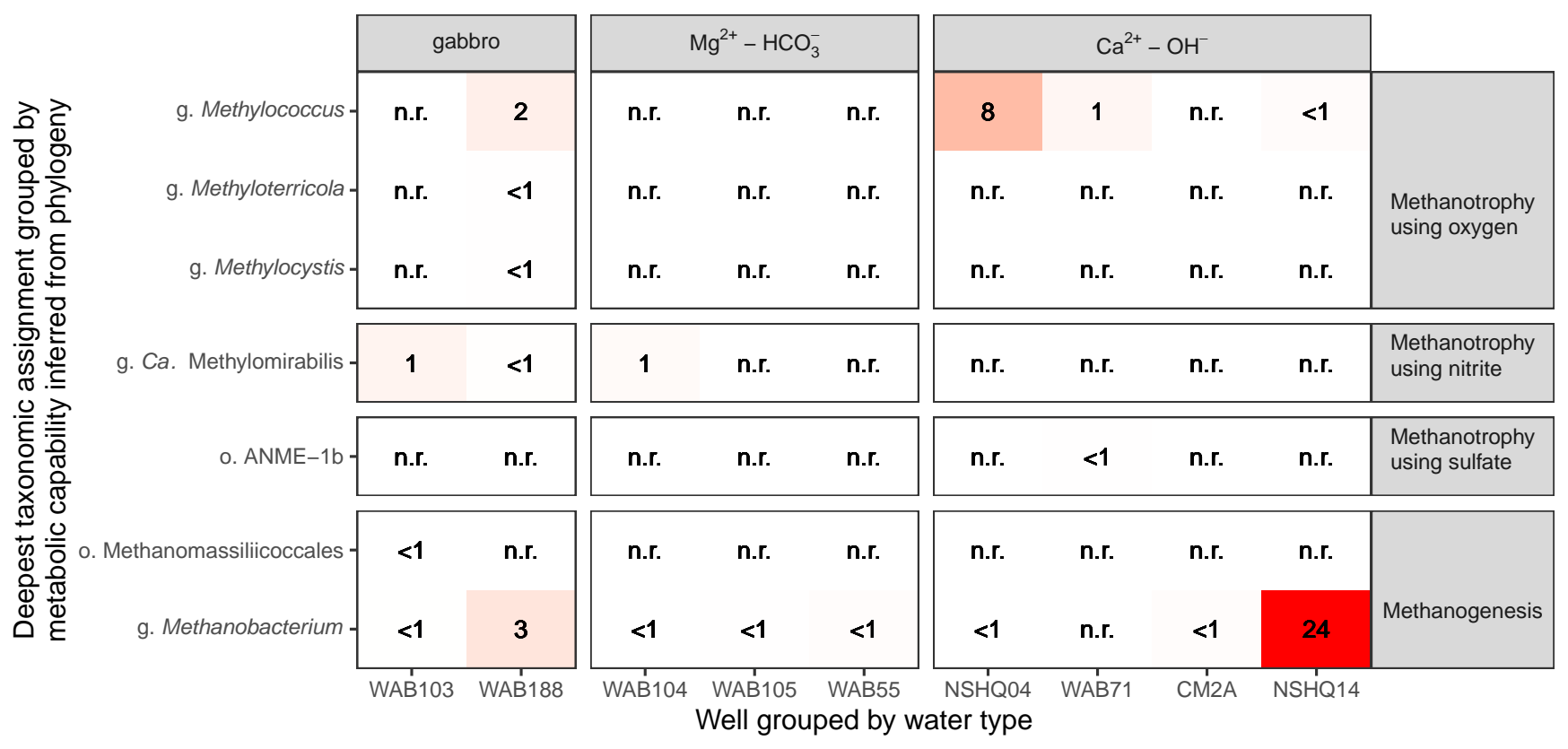

Read relative abundance / [\%] 
Figure 6. 
Rain: pH 5.5

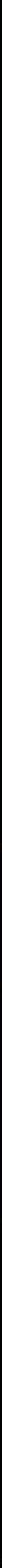

